\title{
Competition and Cooperation
}

\author{
in Mutual Fund Families*
}

\author{
Richard Burtis Evans ${ }^{\dagger} \quad$ Melissa Porras Prado ${ }^{\ddagger}$ \\ Rafael Zambrana Galacho ${ }^{\S}$
}

April 2, 2019

\begin{abstract}
Using manager compensation disclosure and intra-family manager cooperation measures, we create indices of family-level competitive/cooperative incentives. Families that encourage cooperation among their managers are more likely to engage in coordinated behavior (e.g., cross-trading, cross-holding) and have less volatile cash flows. Families with competitive incentives generate higher performing funds, a higher fraction of "star" funds, but greater performance dispersion across funds. In examining the determinants of incentive schemes, competitive families are more likely to manage institutional money, and cooperative families are more likely to distribute through brokers, consistent with retail demand for nonperformance characteristics.
\end{abstract}

JEL classification codes: G11, G23, J33, J44, L22, L25, L84, M12, M52

Keywords: Mutual fund, manager, compensation, incentives, competition, cooperation, cross-holding, performance, cross-subsidization, internal capital markets

*This work was funded by Fundação para a Ciência e a Tecnologia (UID/ECO/00124/2013 and Social Sciences DataLab, Project 22209), POR Lisboa (LISBOA-01-0145-FEDER-007722 and Social Sciences DataLab, Project 22209) and POR Norte (Social Sciences DataLab, Project 22209). We thank David Chapman, Darwin Choi, Alan Crane, Mike Gallmeyer, Miguel Ferreira, Javier Gil-Bazo, Viktoriya Lantushenko, Marc Lipson, Elena Loutskina, Pedro Matos, Jonathan Reuter, and Luis Vicente for their helpful comments. We thank seminar participants at the 2018 American Finance Association, ESSEC, Nova BPI Asset Management Conference, University of Georgia, University of Mannheim, ESMT 4th Annual Asset Management Conference, 25th Finance Forum in Barcelona, the McIntire School and Darden School at the University of Virginia, 2017 Southern Finance Association, and the 2017 Northern Finance Association. We are also grateful to Diane Del Guercio, Egemen Genç, and Hai Tran, who provided the side-by-side mutual fund/hedge fund manager data used in our analysis. Corresponding author: Melissa Porras Prado, Address: Nova School of Business and Economics, Universidade NOVA de Lisboa, Campus de Carcavelos, Rua da Holanda 1, 2775-405 Carcavelos, Portugal.

$\dagger$ Darden School of Business at the University of Virginia. E-mail: evansr@darden.virginia.edu.

${ }^{\ddagger}$ Nova School of Business and Economics. E-mail: melissa.prado@novasbe.pt.

$\S$ Nova School of Business and Economics. E-mail: rafael.zambrana@novasbe.pt. 


\section{Introduction}

Performance competition is one of the central tenets of the academic study of asset management. Because investors respond positively to good performance and management fees are proportional to fund size, evidence suggesting that managers compete to outperform one another is not surprising. There is a long literature examining this performance competition, specifically among mutual fund managers. Brown, Harlow, and Starks (1996) and Chevalier and Ellison (1997) show that fund managers exhibit tournament-like behavior consistent with strong incentives to outperform. ${ }^{1}$ Overall, this literature suggests that managers have strong incentives to compete on performance.

Separate from this literature on manager competition, there is a growing literature documenting coordinated behavior across funds that are part of the same fund family. Gaspar, Massa, and Matos (2006) find evidence consistent with the strategic transfer of performance from low-to high-value funds within a family. Bhattacharya, Lee, and Pool (2013) show that affiliated fund-of-mutual funds invest in other funds in the family when redemptions from those funds become severe. While these actions can be justified from the perspective of maximizing the value of the fund family, they suggest a degree of cooperation among fund managers that stands in stark contrast to the suggested competition documented in the manager tournament literature. How can we reconcile evidence of both cooperation and competition among fund managers? Are the investment decisions of each fund manager focused on maximizing their own fund's performance or the overall value of the investment advisor?

In this paper, we examine how competitive and cooperative fund manager incentives affect fund and family strategies and outcomes. We begin our analysis by constructing two indices of fund manager incentives, competitive and cooperative, and then taking the difference between the two to get a net competitive/cooperative incentive index.

Looking to the academic literature on asset management to guide our index construction, we identify 12 variables that have been used to characterize fund manager incen-

\footnotetext{
${ }^{1}$ Kempf and Ruenzi (2007) examine tournaments within mutual fund families and find that managers adjust their risk in response to their performance rank within the family relative to other funds in the same investment objective. Schwarz (2011) suggests a methodological improvement in measuring tournament behavior using fund holdings but also finds strong evidence of managerial performance competition.
} 
tives and classify them as competitive or cooperative. While the data source and unit of observation differs across the variables, they fall into two broad categories: manager compensation incentives (e.g., manager ownership of the fund corresponds to competitive, manager ownership of the investment advisor corresponds to cooperative) and fund management structure (e.g., solo-managed fund corresponds to competitive or teammanaged corresponds to cooperative). ${ }^{2}$ For each of the 12 variables, the average across all funds in the family is computed, and this family-level average is ranked within the cross-section. To aggregate them into a single competitive (cooperative) incentive index for each family and date, an equal-weighted average of the six family-level competitive (cooperative) variable ranks is calculated.

We then use these indices to examine the relation between family incentives and both fund and family outcomes. We would expect managers who work for families with cooperative incentive schemes to be more willing to assist other managers in the same family. To test for the existence of cooperation, we examine the impact of incentives on cross-trading and cross-holdings. Cross-trading, or the crossing of trades between two funds in a family, and cross-holding, or the purchase of one fund in the family by another, are cooperative activities. The evidence in Gaspar, Massa, and Matos (2006) and Bhattacharya, Lee, and Pool (2013) suggest that cross-trading and cross-holding, respectively, can be used to transfer performance from low-to high-value funds. If the compensation scheme at the advisor is competitive in nature, it would be surprising for one manager to sacrifice the performance of his or her own fund (and their compensation) even if there was a net benefit to the family. However, a cooperative incentive scheme, like bonuses tied to the overall profitability of the fund family, might induce a manager to sacrifice the performance of his or her own fund by offering performance transfer via cross-trading or flow insurance via cross-holding. When we examine the determinants of cross-trading and cross-holding, we find that families with a cooperative incentive scheme are more likely to have higher levels of cross-trading and cross-holdings.

\footnotetext{
${ }^{2}$ The six competitive incentive variables include a solo-managed fund indicator; three indicator variables of whether or not a manager's bonus was based on fund performance, fund revenue, or paid in fund shares; a Coles incentive rate variable measuring the concavity of the fund fee; and the range of manager ownership of a fund. The six cooperative incentives variables include: a team-managed fund indicator, the average ratio of the number of managers per fund, and a measure of the degree of manager interconnection within the family; two indicator variables of whether or not the manager's bonus is paid in advisor equity or based on advisor level activities of the manager; and an indicator variable of whether or not the fund's fee is based on the assets or performance of other funds in the family. The Appendix walks through a specific example of the index construction for the Janus Fund.
} 
For competitive incentives, we first examine the relation to manager effort using active share and tracking error as proxies. We find managers in families with greater competitive incentives have higher active share and tracking error. While this result is also consistent with competitive incentives attracting managers with higher ability, we also examine the active share and tracking error of managers who move from a cooperative to a competitive incentive scheme, thereby controlling for manager ability, and we find both measures increase, consistent with incentivizing greater effort.

To better understand how competitive and cooperative incentives affect the firm overall, we turn to the internal capital markets literature that provides an important framework for our tests. Williamson's (1975) seminal work on the boundaries of a firm, formalized in Stein (1997), point to managerial incentives at a division level as a key determinant of the efficacy of internal capital markets:

"Closer adherence to the goals of the general management can be secured if the special incentive machinery to which internal organization uniquely has access is consciously exercised to favor operating behavior that is consistent with the general management's objectives... That salaries and bonuses can be adjusted to reflect differential operating performance, assuming that such differentials exist and can be discerned, is a familiar application of the incentive machinery."

If their incentives encourage division managers to cooperate with the CEO and each other in trying to achieve the overall aims of the firm ("behavior... consistent with...general management's objectives"), internal capital markets can be firm-value improving. While cooperative incentives increase firm-wide cooperative behaviors such as cross-trading and cross-holding, the net effect to the firm is unclear. Hann, Ogneva, and Ozbas (2013) provide one perspective on how effective internal capital markets should affect the firm. Specifically, they show that when efficient investment occurs via internal capital markets, the coinsurance inherent in such an arrangement can reduce systematic risk across the firm. In our mutual fund setting, we test for this coinsurance effect using two measures. First, in the full sample, we look at the volatility of advisor revenue as a proxy for cash flows and find higher cooperative incentives are associated with lower volatility. Second, while advisor revenue is only a proxy for firm cash flows, for a subset of our sample managed by publicly traded investment advisors, we collect actual firm cash flows and the associated return on assets. Consistent with a coinsurance 
effect, both cash flow and return on assets volatility decrease with increased cooperative incentives.

The internal capital markets literature also sheds light on competitive incentives. Both Scharfstein and Stein (2000) and Rajan, Servaes, and Zingales (2000) model internal capital markets where the incentives of division managers differ from those of the CEO or "headquarters." These differences in incentives, consistent with division or fund-specific competitive incentives, result in distortions in optimal resource allocation. Consistent with such distortions, we find that funds from families with competitive incentives exhibit less cross-trading and cross-holding and greater dispersion in fund returns across the family (i.e., more winners and losers). While these "dark side" models highlight how competitive incentives can skew the split of the surplus across parties, they don't allow for such incentives to increase the size of the surplus generated by different incentives. When we look at performance, however, we find that competitive incentives are associated with a higher percentage of "star" funds and higher average performance overall, consistent with incentivizing greater effort or attracting managers with higher abilities.

Our competitive incentives results taken as a whole highlight the important trade-off that such incentives provide. While the lack of coordination between the objectives of these higher effort/higher skill managers and the investment advisor may result in the dark side of internal capital markets, those negative effects must be weighed against higher overall performance in our context or a larger overall surplus in a more general internal capital markets context.

While both competitive and cooperative incentives have pros and cons, the sample consists of investment advisors with both net competitive and net cooperative incentives. Moreover, family transitions from one incentive scheme to the other are infrequent, suggesting a fixed incentive regime over time. ${ }^{3}$ What factors then determine which incentive scheme each family chooses? Gârleanu and Pedersen (2018) propose a model that gives us some insight into what strategic dimensions of an investment advisor's business might be associated with each incentive choice. They model the equilibrium choice of investors to invest directly or to use an asset manager to invest on their behalf.

\footnotetext{
${ }^{3}$ Transitions from above median cooperative incentives to below median constitute only $0.95 \%$ of the sample, and transitions from below median cooperative to above median cooperative constitute only $1.59 \%$ of the sample.
} 
They find that institutional investors (i.e., investors with lower search costs relative to their assets to be invested) benefit from searching for informed managers. Considering our results in the context of their model, we find that competitive investment advisors are more likely to have institutional clients, and cooperative advisors are more likely to sell through a broker channel. Our results are consistent with their model on two dimensions. First, with greater competitive incentives, cross-fund subsidization is discouraged. As a result, the performance or quality signal about each manager is clearer in a competitive fund family since fund performance is more likely to represent manager ability than intrafamily support. If institutional investors benefit from searching for superior managers, they would be more likely to search among competitively incentivized fund managers. Second, if retail investors have less ability to identify superior managers, selecting a manager from a competitive family may constitute additional risk due to the greater dispersion of performance outcomes. Broker-sold funds, on the other hand, exhibit less dispersion, and the selection of the manager is outsourced to someone else. The analog in Gârleanu and Pedersen (2018) is their prediction that small investors should choose passive vehicles, but their result is also driven by the risk of uninformed investor choice between funds/managers with disperse performance outcomes. As a whole, our results are consistent with the equilibrium proposed by and the intuition underlying the Gârleanu and Pedersen (2018) model.

One possible concern with our analysis is the potential endogeneity of the fund family's incentive scheme choice. To address this issue, we use investment advisor mergers as an exogenous source of incentive variation (i.e., a competitive advisor acquires a cooperative advisor) and confirm our primary results regarding family incentives affecting portfolio outcomes. We also employ a falsification test, creating a pseudo family from our sample of funds that is matched on family size and investment-style characteristics but not on incentives. Consistent with competitive and cooperative incentives driving the results, when we repeat the primary tests in the paper, we find no relation between incentives and outcomes for random family assignments.

The rest of the paper proceeds as follows. Section 2 describes the data used and the construction of the competition/cooperation measure. We then present our results in two sections. First, in Section 3 we present the family-level outcomes of competitive incentives (performance and dispersion) and cooperative incentives (family revenue, cash 
flow and return on assets volatility). Second, in Section 4 we then examine evidence on potential mechanisms of how incentives could affect family-level outcomes. For competitive incentives, we look at active share and tracking error. For cooperative incentives, we look at the coordinated activities of cross-trading and cross-holding. Section 5 examines why fund families differ in their incentive structure. Section 6 shows additional robustness tests conducted, and Section 7 concludes.

\section{Data}

We examine actively managed US mutual funds from five different asset classes: domestic and international equity, domestic and international bond, and balanced portfolios, over the 1992-2015 time period. We combine data from several sources for our analysis. First, advisory and portfolio manager incentive contract data come from the Securities and Exchange Commision (SEC) semiannual N-SAR and the statement of additional information (SAI) filings. As of 2005, the SEC started requiring advisors to disclose the factors used to determine the compensation of individual fund managers in the fund's SAI; therefore, the individual contract data from this statement run from 2005 to $2015 .{ }^{4}$ The N-SAR data are available through the SEC EDGAR database starting in 1996.

Second, we use the Center for Research in Security Prices (CRSP) Survivorship BiasFree Mutual Funds Database. It provides names of the management companies, funds returns, total net assets under management (TNA), funds inceptions, turnover, expenses, and other fund and family characteristics. While CRSP provides portfolio manager names (only last names when the fund has multiple managers), a unique identifier for those managers is not available. To assign a unique identifier to each manager, we obtain the full names of managers from Morningstar Direct and append that data to the mutual fund portfolio manager and company names retrieved from CRSP. This manager history data predate the beginning of our sample period. Morningstar Direct also provides the portfolio manager fund ownership data that begin in 2005.

Finally, the CRSP and Thomson Reuters mutual fund holdings databases are used to compute the portfolio level cross-trading and cross-holding measures, respectively. The

\footnotetext{
${ }^{4}$ Disclosure Regarding Portfolio Managers of Registered Management Investment Companies, SEC Release No. IC-26533 (2005).
} 
CRSP data have a higher reporting frequency and are therefore used to identify crosstrades (matched purchase and sale transactions of the same number of shares of the same stock from two funds in the same family) at a monthly frequency from 2004 to 2015 . The quarterly Thompson holdings data cover our sample period (1992-2015) and are used for the cross-holdings measure where higher frequency data are not required. Additionally, we use data on investment advisors' cross-trading practices from the uniform application for investment advisor registration (form ADV) that are available from 2001 to 2015. In these filings, the SEC requires fund advisors to report on the extent of their crosstrading activity, avoiding the need to infer it from holdings or trade data. All stock-level information is obtained from CRSP. The definition of all variables used in the analysis is provided in the Data Appendix.

\subsection{Competition and cooperation indices}

To estimate the nature of incentives at the advisor level, we construct both a competitive and cooperative incentives index. To construct these indices, we first identify from the academic literature variables used to characterize fund manager incentives and classify them as competitive or cooperative. While our empirical design focuses on the overall incentive environment at the investment advisor, we also provide the regression results for each of the individual components in the Internet Appendix (i.e., see Tables A1, A2, and A3) for completeness. Below we describe the motivation and the data sources for the different components of these two indices. We also provide a detailed example of how the index is constructed for a specific fund and family in the Appendix.

\subsubsection{Individual versus team fund management}

There are a number of papers that examine the role of individual versus team management in mutual funds. ${ }^{5}$ While the focus of these papers is not incentives per se, they do give insight into how the investment advisor's decision to put a single individual or a team in charge of a fund relates to those incentives. Bliss, Potter, and Schwarz (2008), for example, find that team-managed funds have less performance dispersion and greater similarity in their portfolio factor loadings than their individual-managed counterparts

\footnotetext{
${ }^{5}$ For example; see Prather and Middleton (2002); Bliss, Porter, and Schwarz (2008); Massa, Reuter, and Zitzewitz (2010); Bar, Kempf, and Ruenzi (2011); Rau (2015); Patel and Sarkissian (2017); and Adams, Nishikawa, and Rao (2018).
} 
consistent with greater cooperation among team managers. While the focus of Massa, Reuter, and Zitzewitz (2010) is the role of anonymous teams, their results also show that team funds are more likely to cross-subsidize other funds. They also find evidence consistent with greater labor incentives for named solo managers that might engender greater effort or attract individuals with greater ability. Together, these papers suggest that team-managed funds and the associated network of interconnected managers within an advisor may engender cooperative behavior across funds in the family. Similarly, the incremental flows and greater labor mobility associated with named solo managers suggests competitive incentive implications for funds with solo/individual managers. For these reasons, we include in our indices a measure of individual-managed funds, team-managed funds, the number of managers per fund, and the interconnectedness of managers across funds.

These four manager variables are constructed from the Morningstar manager history data. The data cover our entire sample period of 1992 to 2015 and form the foundation for our competitive and cooperative indices. Using this history of managers, we calculate the proportion of funds within a family that is managed by an individual fund manager (Individual fund) and by a team, (Team fund) and the average managers per fund (Managers/Fund ratio) across the family. We also use these data to calculate a measure of how interconnected managers are across different funds in the family. This measure is calculated as the ratio of the number of funds in the family with manager overlap (at least one manager is on the team overseeing both funds) in the same investment objective divided by the number of funds in the family in the same investment objective (Manager connected).

\subsubsection{Manager compensation}

Farnsworth and Taylor (2006) provide a broad overview of potential incentive mechanisms through their manager survey of the determinants of portfolio manager compensation. These mechanisms include both fund-level variables (e.g., fund performance, assets, flows) and advisor level variables (e.g., advisor profitability, stock price performance, nonperformance-related factors such as employee development, and noncash or equity compensation). Supportive of the motivation underlying our paper, Farnsworth and Taylor (2006) express surprise at how important the advisor-level variables are reported 
to be by managers relative to fund-level determinants. In discussing why this might be the case, they point to the mutual fund late-trading scandal as anecdotal evidence of the role of cooperative incentives. Specifically, they point out that the late-trading scandal required mutual fund managers to cooperate in sacrificing the performance of their own fund to benefit the advisor as a whole. This cooperation would be harder to obtain if the manager's investment performance determines bonuses but much easier to obtain when firm profits determine bonuses.

While the Farnsworth and Taylor (2006) analysis consists of a small sample of survey responses, two recent papers have collected and analyzed investment advisor managerial incentive disclosures. Using the 2005 SEC rule change requiring investment advisors to detail the determinants of manager compensation, Ma, Tang, and Gomez (2018) analyze a set of manager incentive variables including whether or not a manager's compensation is based on fund performance, advisor profitability, and whether or not it is paid via deferred compensation. Lee, Trzcinka, and Venkatesan (2018) also collect manager compensation variables to revisit the manager risk-shifting hypothesis. They identify whether or not a manager's bonus is determined relative to a benchmark and how clearly that benchmark is identified.

Drawing on the insights of Farnsworth and Taylor (2006), Ma, Tang, and Gomez (2018), and Lee, Trzcinka, and Venkatesan (2018), we collect a similar set of managerial incentive variables. For our competitive index, we include three indicator variables as to whether or not a manager's bonus is determined by fund performance (Bonus-fund performance), fund revenue (Bonus-fund revenue), and whether or not the bonus was paid, at least in part, by a grant of fund shares (Bonus-paid in fund shares). For the cooperative index, we include indicator variables as to whether or not a manager's bonus is paid in equity of the advisor (Bonus-Paid in advisor equity $)^{6}$ and had advisor-level determinants (Bonus-Advisor Level Determinant). ${ }^{7}$ The latter variable is yes when the compensation disclosure makes clear that manager level effort in advisor-level activities

\footnotetext{
${ }^{6}$ Our bonus paid in fund shares/equity of the advisor differs somewhat from the deferred compensation variable collected by Ma, Tang, and Gomez (2018). Instead of aggregating all deferred compensation types, we separate out advisor equity and fund share grants as compensation, regardless of whether they are deferred or not.

${ }^{7}$ Our advisor-level determinants variable also differs from the Ma, Tang, and Gomez (2018) advisor profitability variable. While many investment advisors indicate that the size of their bonus pool depends on the overall profitability of the advisor, our advisor-level determinants variable focuses instead on the use of manager level effort/activity as it relates to advisor-level activities being used to determine a bonus. We discuss this issue in more detail in the Appendix.
} 
(e.g., employee mentoring, advisor strategy) is used as a factor in determining the bonus. As an additional measure of cooperative incentives, we also include an indicator of whether or not the fund's advisory fee was based entirely or partially on the performance, assets, and income of other funds in the family (Other funds fee). ${ }^{8}$ If the advisory fee is based not only on the fund in question but on other funds, a manager of a fund with such a fee arrangement may be more inclined to cooperate with the managers of other funds upon which the joint fee criteria is based.

The three competitive (Bonus-fund performance, Bonus-fund revenue, and Bonuspaid in fund shares) and two cooperative (Bonus-paid in advisor equity, and Bonusadvisor level determinant) manager compensation variables are hand collected from each fund's SAI filings. The SEC first required investment advisors to disclose the determinants of manager compensation in late 2005. Because of the difficulty of collecting these data by hand and because they do not change much over time as documented by Ma, Tang, and Gomez (2018), we collect two snapshots of the data from 2006 and 2009 and backfill the data to cover the sample period of our team management variables. ${ }^{9}$ The cooperative fund advisory fee variable (Other funds fee) is taken from question 52 of the fund's semiannual report or N-SAR. These N-SAR reports are required for all funds by late 1995, so before this date, we backfill this variable with the earliest observational value.

\subsubsection{Coles incentive rate}

Massa and Patgiri (2009) examine the role of manager incentives on performance and risk-taking. While they do not measure manager incentives directly, they follow the insights of Coles, Suay, and Woodbury (2000) in using the shape of the fund advisory contract as a proxy for those incentives.

Specifically, they calculate the percentage change in the advisory fee between the highest TNA and lowest TNA breakpoints, a measure that they term Cole's incentive rate $(\mathrm{CIR})$. The intuition behind their measure is simply that fund managers with a linear advisory fee (CIR of zero) have greater incentives to generate performance as

\footnotetext{
${ }^{8}$ As an example, the Fidelity Diversified Stock Fund pays a management fee to the advisor (FMR) that adds a group fee rate of $0.25 \%$ to an individual fund fee of $0.17 \%$. The group fee rate is based on the average net assets of all the mutual funds advised by FMR.

${ }^{9}$ Our results are robust to restricting the sample period to the availability of the common data period (2005-2015); see Internet Appendix Table A4, panel G.
} 
the fund size grows, compared to managers with concave fee structure (CIR less than zero). Consistent with a competitive incentive, they find that a higher CIR results in higher performance and risk-taking. Given this strong support for CIR as a measure of competitive incentives, we include it in our index $(C I R)$.

To calculate the CIR measure, we collect each fund's response to N-SAR question 48. CIR measures the concavity of the advisory contract defined as the difference between the last and first marginal compensation rates divided by the effective marginal compensation rate. Thus, the shape of the contract takes the value zero for linear contracts and negative values for concave contracts, with the competitive incentive increasing as this variable increases.

\subsubsection{Manager ownership}

Last of all, Khorana, Servaes, and Wedge (2007) show that manager fund ownership is positively related to performance. Using the March 2005 SEC rule change requiring disclosure of manager ownership in a fund (the SEC requires managers to disclose the value of their fund ownership across 7 ranges: None; $\$ 1-\$ 10,000 ; \$ 10,001-\$ 50,000$; $\$ 50,001-\$ 100,000 ; \$ 100,001-\$ 500,000 ; \$ 500,001-\$ 1,000,000$; or more than $\$ 1,000,000)$, they examine both the determinants of manager ownership and its impact on performance. While the increase in performance is modest ( $\sim 3$ basis points for a 1 basis point increase in ownership), the Khorana, Servaes, and Wedge (2007) results are consistent with increased competitive incentives due to the manager's ownership in their specific fund. Consequently, we include a measure of manager ownership (Manager ownership) in our competition index. To capture the manager fund ownership level, we use Morningstar's ownership range data, which rank manager ownership from one to seven across the seven ranges, with a higher rank corresponding to higher ownership.

\subsubsection{Competition, cooperation, and net competition indices construction}

The competition index is constructed at the management company-year level as the average across the six competition variables described above: Individual Fund constructed from the Morningstar manager history data; Bonus-fund performance, Bonusfund revenue, Bonus-paid in fund shares hand collected from the SAI filings; CIR measure constructed from the N-SAR advisory fee reporting; and the Manager ownership 
range from Morningstar.

We average each of the variables across all funds in the family. We then calculate a decile rank of the family-level variable across all families for a given date, to remove any time trends. The competition index for family $i$ at time $t$ is then the average of these six rank variables described above, which ranges from zero to one:

$$
\begin{array}{r}
\text { Competition }_{i, t}=\left(\text { Individual fund }_{i, t}^{\text {DecRnk }}+\text { Bonus-fund performance }_{i, t}^{\text {DecRnk }}\right. \\
+ \text { Bonus-paid fund shares } s_{i, t}^{\text {DecRnk }}+\text { Bonus-fund revenue }_{i, t}^{\text {DecRnk }} \\
\left.+C I R_{i, t}^{\text {DecRnk }}+\text { Manager ownership } i_{i, t}^{\text {DecRnk }}\right) / 6 .
\end{array}
$$

The cooperative incentives index is also aggregated at the management companyyear level using the other six variables described above. These variables include Team fund, Managers/Funds ratio, and Manager connected constructed from the Morningstar manager history data; Bonus-paid in advisor equity and Bonus-advisor level determinant hand collected from the SAI data; and the Other funds fee taken from the N-SAR data. With these variables, the cooperative incentives index is computed in the same manner as the competition index:

$$
\begin{aligned}
& \text { Cooperation }_{i, t}=\left(\text { Team fund } d_{i, t}^{\text {DecRnk }}+\text { Managers } / \text { Fund ratio }{ }_{i, t}^{\text {DecRnk }}\right.
\end{aligned}
$$

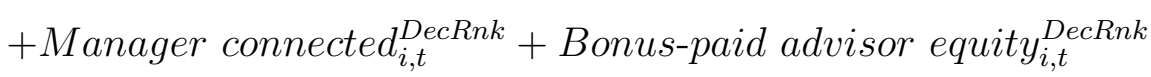

$$
\begin{aligned}
& \left.+ \text { Bonus-advisor level determinants }{ }_{i, t}^{\text {DecRnk }}+\text { Other funds } f e e_{i, t}^{\text {DecRnk }}\right) / 6 \text {. }
\end{aligned}
$$

The values of both Competition $_{i t}$ and Cooperation $i t$ are standardized annually (with zero mean and standard deviation of one) to isolate the cross-sectional differences of the competitive and cooperative incentives schemes across investment advisors. ${ }^{10}$ Finally, we also calculate the net incentive as the difference between the competitive and cooperative incentives (Net competitive), as fund families can have elements of both incentive structures in place, but our focus is their overall incentive environment. ${ }^{11}$

\footnotetext{
${ }^{10}$ While in this paper we abstract from the time-series variation of the incentive measures by ranking the components within each cross-section, the time-series variation of the net competition measures constructed using the individual versus team-fund management variables and manager compensation components of the index are separately plotted in Fig. A1 of the Internet Appendix.

${ }^{11}$ To ensure robustness, we repeat the primary regressions in the paper constructing the indices a variety of ways. In Table A5 of the Internet Appendix, we repeat the analysis using only the domestic
} 


\subsection{Summary statistics: competitive versus cooperative families}

In Table 1 we present the fund-level averages of the variables that comprise the index. Because the management fee structure of the average fund is concave (i.e., the advisory fee decreases as the total assets increase), the average CIR is negative. In terms of the fund management structure, on average, $41 \%$ of funds are managed individually, $59 \%$ are team-managed funds, and the average number of managers per fund is 2.74 . The Manager connected variable shows that there is just under $16 \%$ manager overlap, on average, across funds offered by the same advisor in the same investment objective. In terms of compensation, the managers of $83 \%$ of funds receive a bonus based in part on fund performance, $14 \%$ based on fund revenue, and $31 \%$ based on various advisor-level determinants, while only $8 \%$ of fund fees are based on the performance of other funds. This compensation is paid in part via grants of fund shares for managers of $4 \%$ of funds and via equity in the advisor for $73 \%$. Last of all, the average ownership of managers is 2.5 , which corresponds to ownership between the $\$ 1-\$ 10,000$ and $\$ 10,001-\$ 50,000$ categories.

\section{[Insert Table 1 here]}

In Table 1 we also present the correlation matrix between the competition and cooperation variables used to construct the indices. While the average correlation and the majority of correlations are positive within the six competitive and six cooperative incentive component subgroups, and the average cross-correlations and the majority of cross-correlations across the competitive and cooperative components are negative, there are positively correlated competitive and cooperative index components. The use of bonuses based on fund performance and bonuses paid in advisor equity, for example, are positively correlated. While Ma, Tang, Gomez (2018) do not distinguish between the competitive and cooperative nature of manager incentives, they also find that many advisors use both of these incentives. Because the different incentive mechanisms can be used as complements or substitutes, combining them into a single index will give a

equity funds of an advisor to construct the index (Panel A), TNA-weighting (Panel B), and equalweighting (Panel C) the components. We also construct the index using the decile ranking procedure from above but calculating those ranks within investment objective (Panel D). Last of all, we use the first three components of a principal components analysis of the cooperative (Panel E) and competitive (Panel F) incentive measures as an alternative index construction. The results are broadly consistent across all of these different approaches to index construction. 
better sense of overall incentive environment at the advisor. In spite of the low correlations among many of the components, we find that after aggregating these different components into our competitive and cooperative indices, the correlation between the two is -0.54 and strongly statistically significant. This serves as a point of validation for the index construction approach: in spite of the low correlations between individual components, when aggregating them, those advisors with strong (weak) competitive incentives, on average, have weak (strong) cooperative incentives.

Table 2 compares the fund (Panel A) and family (Panel B) characteristics of competitive and cooperative families. In this table, funds are classified as being in a competitive or cooperative family if their families score above or below the median net competition index value. Looking at the fund results first, we see that funds with competitive incentives are older and perform better. This is consistent with longer survival rates for competitively incentivized funds and competitive incentives engendering greater effort from managers and/or attracting greater managerial talent. Funds with cooperative incentives are more likely to be sold through a broker-distribution channel as we see from their higher sales loads. In terms of the cross-sectional variation in incentive schemes between investment advisors (Panel B), cooperative firms are larger and offer more funds. Competitive advisors tend to have higher cash levels, higher expense ratios, and a higher percentage of star funds.

[Insert Table 2 here]

\section{Incentives and family level outcomes}

In this section, we examine the relation between family-level outcomes of competitive incentives (performance and dispersion) and cooperative incentives (family revenue and cash flow volatility). In Section 3.1, we look at average fund performance, the percentage of star funds in a family, and performance dispersion across funds in the same family. In Section 3.2, we present results on family-wide advisory revenue volatility for the whole sample and cash flow and return on assets volatility for a subsample of advisors that are publicly traded. 


\subsection{Performance}

Given the central role that performance competition plays in the asset management industry, we begin our analysis by analyzing the relation between competitive incentives and fund performance. We first test at the individual fund level whether the incentive differences affect the fund's gross investment objective-adjusted performance and whether net competitive fund families have a higher fraction of star funds. In Table 3, we look at the relation between competitive and cooperative incentives and the objective-adjusted gross performance across individual active funds in the family. The regressions are run using the Fama-MacBeth (1973) methodology with standard errors adjusted for serial correlation using Newey-West (1987). As the results show, performance and competitive incentives are positively related: funds with higher competitive incentives outperform other active funds by 1.9 basis points per month or 23 basis points per year for every one standard deviation increase in the competitive index without fund-level controls and 1.7 basis points per month with fund-level controls. We find similar results when we repeat the analysis with net returns (Table A6 in the Internet Appendix) or using the stock selection (CS), the timing measure (CT), or combined into the overall DGTW risk-adjusted performance measures of Daniel et al. (1997), the Capital Asset Pricing Model (CAPM) alpha measure of Jensen (1968), and the four-factor alpha measure of Carhart (1997) and Fama and French (1992) (See Table A7 in the Internet Appendix).

\section{[Insert Table 3 here]}

In Table 4 we measure the relation between incentives and the fraction of star funds in the family. We measure star funds as those portfolios with past three-year cumulative investment objective-adjusted gross returns in the 95th percentile or greater, within their investment style in a given month. We see that a one standard deviation increase in competition translates into about $1.9 \%$ more star funds in the family without family controls and $1.7 \%$ including controls. Cooperative incentives, on the other hand, reduce the number of star funds. Fund families that are net competitive have $1.9 \%$ more star funds with each one standard deviation increase in net competitive incentives. Repeating the analysis at the fund level in a logistic specification or at a family level where we classify families as competitive or cooperative, we confirm these results (See Tables A8 and A9 in the Internet Appendix). 
[Insert Table 4 here]

While improved performance is an important outcome of competitive incentives, the internal capital markets literature also suggests that such incentives can result in firm-wide distortions. Without trading coordination, information sharing, and other forms of cooperation that competitive incentives may discourage, we would expect bigger differences in performance between funds or, effectively, greater dispersion in fund performance outcomes. Table 5 reports regression results of the monthly cross-sectional standard deviation of fund style-adjusted returns across all funds in the family on the competitive, cooperative, and net competitive indices and controls. We find that more competitive families have higher cross-sectional dispersion in performance, whereas cooperative incentives translate into lower dispersion. We also show that the net competitive incentive schemes are positively associated with performance dispersion at the fund family level. A single unit increase in the Net competitive index is associated with about $0.04 \%$ greater dispersion in performance with family-level controls. Using above median indicator variables for competitive and cooperative families, we observe $0.056 \%$ greater dispersion for competitive families, which represents about $5 \%$ of the average dispersion (see Table A10 of the Internet Appendix).

\section{[Insert Table 5 here]}

Overall, we find that advisors with greater competitive incentives offer funds with higher average performance and a higher percentage of star funds. At the same time, consistent with a lack of coordination, the dispersion in performance across funds within an advisor with competitive incentives is higher as well.

\subsection{Fund family revenue and cash flow volatility}

Given the higher fund performance and larger percentage of star funds associated with competitive incentives, why might an investment advisor choose a cooperative incentive scheme? The internal capital markets insights of Williamson (1975), Stein (1997), Scharfstein and Stein (2000), and Rajan, Servaes, and Zingales (2000) shows that the firm-value improving benefits of internal capital markets occur under a cooperative incentive scheme. Such a scheme aligns the incentives of the division manager with those of the CEO or firm headquarters. If the objective is to maximize the overall value of the 
investment advisor, coordinated action among fund managers may be an important tool to accomplish this objective. In this section, we explore the implications of cooperative and competitive incentives for firm-wide cash flows. We first use advisor revenue as a proxy for such cash flows across the whole sample. We then focus on the subset of publicly traded investment advisors, using their accounting disclosures to examine cash flow and return on assets volatility.

In Table 6 we measure the relation between the volatility of advisor revenues and competitive/cooperative incentives controlling for family size and other family-level characteristics. The advisory fee revenue data is collected from question 72 .F of each fund's N-SAR filing and is then aggregated across the family. The dependent variable is the volatility of these advisory fees calculated over the previous 24 months. Consistent with the coinsurance effects suggested by Hann, Ogneva, and Ozbas (2013), we find that competitive incentives are associated with higher volatility in family revenue over time, while cooperative incentives are associated with lower volatility. In Table A11 of the Internet Appendix, we repeat the analysis using the flow recapture framework of Christoffersen, Evans, and Musto (2013). There we find that advisors with competitive incentives are worse at recapturing outflows from other funds, but consistent with greater coordination and cooperation across the enterprise, advisors with cooperative incentives are better at retaining assets.

\section{[Insert Table 6 here]}

While advisor revenue is a proxy for firm-level cash flows, ideally we would prefer to analyze firm cash flows and the return on assets, directly. While many investment advisors are privately held and therefore do not disclose this information, there is a subset of asset management companies that are publicly held. This subsample gives us a unique opportunity to look at how portfolio management incentives affect the stability of the sponsor's overall cash flows.

To identify publicly traded advisors, we use a methodology similar to that employed by Sialm and Tham (2016), Kosovetsky (2016), and Zambrana (2017). We begin by obtaining the names of management companies and their corresponding management codes from the CRSP mutual fund database. To take into account mergers affecting fund advisors or their parent companies, we search for each advisor's name into the SEC's 
Investment Advisor Public Disclosure (IAPD) online database and look up the Schedule A of Form ADV, which lists all direct owners and executive officers. We also extract a list of mergers from the SDC Platinum database and assign the family to the merged companies after the effective date of the mergers. Using these names, we manually search through the CRSP stock database to find the CUSIPs of the corresponding publicly traded stocks. Using the matched CUSIPs, we obtain accounting data for management companies or their publicly-traded parent companies (if the management company is a subsidiary) from Compustat. Overall, our publicly traded fund management companies sample includes 111 fund families that were offering funds during 1992 and 2015. These publicly traded fund families account for $12 \%$ of asset managers in the mutual fund sector.

In Table 7, we examine the stability of cash flows and return on assets of publiclytraded asset management companies. We show that the parent companies of more competitive advisors have more volatile cash flows and return on assets (ROA), while we observe a negative relation for more cooperative families.

\section{[Insert Table 7 here]}

Taken as a whole, the fund performance, star fund, dispersion, and cash flow results form a holistic picture of the use of competitive and cooperative incentives. Cooperative incentives align fund manager incentives with those of the firm. With such incentives in place, fund managers are more willing to sacrifice the performance of their own fund to support other funds in the family that is of strategic importance. Consistent with the insights of Williamson (1975) and Stein (1997) on the bright side of internal capital markets, the overall impact is greater cash flow stability. On the other hand, competitive incentives encourage individualistic fund manager behavior. Consistent with the firmwide distortion suggested by the models of Scharfstein and Stein (2000), and Rajan, Servaes, and Zingales (2000), performance dispersion across funds in the family is higher. At the same time, we also find that competitive incentives result in higher average performance consistent with either incentivizing greater effort on the part of managers or attracting managers with higher ability. This provides a novel insight relative to the internal capital markets literature. Across the different incentive mechanisms in Stein (1997), Scharfstein and Stein (2000) and Rajan, Servaes and Zingales (2000), the overall 
surplus is split differently across the different parties, but if competitive incentives are effective, the level or amount of that surplus may increase due to increased effort on the part of managers.

\section{Fund family incentive structure: mechanism evidence}

In this section, we turn from the family-level outcome evidence to an examination of possible mechanisms for our performance and cash flow stability results. In particular, we test whether or not cooperative incentives are associated with increased coordination (i.e., cross-trading and cross-holding) across funds and whether or not competitive incentives are associated with greater effort on the part of the individual fund managers.

\subsection{Manager effort}

If managers in competitive families have the potential for greater compensation related to the performance of their own fund and their own investment decisions managing that fund, this could engender greater effort on the part of the manager, and/or it could attract managers with greater ability. Consistent with this idea, Kacperczyk and Seru (2015) look at the impact of centralization or decentralization of the research function at the investment advisor and find those managers with greater autonomy in decisionmaking outperform. This outperformance could be due to an increase in managerial effort, with greater autonomy enabling superior managers to add more value through their decisions, or it may be due to the desire of superior managers to work for advisors with a more decentralized research structure. We conduct a similar analysis, looking at the relation between competitive and cooperative incentives and manager effort.

Cremers and Petajisto (2009) and Amihud and Goyenko (2013) both find that managers who deviate more from their benchmark outperform. Using measures of manager deviation from a benchmark (active share and tracking error) as a proxy for manager effort, we examine the relation between incentives and these measures. ${ }^{12}$ Table 8 reports the results of a Fama-Macbeth regression of active share and tracking error on our incentive indices. We include additional controls to account for fund-level heterogeneity such as fund size, fund age, expense ratio, turnover, flows, family size, and the number

\footnotetext{
${ }^{12}$ We thank Martijn Cremers for making the data available through his website.
} 
of funds held in the family. We also include style and time fixed effects to account for systematic differences in style.

\section{[Insert Table 8 here]}

We see from the results in Table 8 that competitive incentives correlate positively with higher active share and tracking error, our proxies for manager effort. A one standard deviation increase in net competitive incentives is associated with an increase in active share and tracking error of $1.5 \%$ and $0.4 \%$, respectively. Similarly, cooperative incentives are associated with lower active share and tracking error. Given the evidence in Cremers and Petajisto (2009) and Amihud and Goyenko (2013) that manager deviation from a benchmark is associated with higher performance, these results suggest a possible mechanism through which competitive incentives materialize into higher average performance across the family, namely greater effort or skill on the part of fund managers.

\subsection{Intra-family coordination}

\subsubsection{Cross-trading}

Gaspar, Massa, and Matos (2006) propose one way in which mutual fund families can transfer performance across member funds: "cross-fund subsidization." Their proposed mechanism involves funds with the lower expected contribution to family profits crosstrading with those funds with a higher expected contribution to family profits, selling below or buying above market prices. ${ }^{13}$ Whether cross-trading is beneficial for the end investor or not, it is a clear example of coordinated action taking place at the fund family level.

To determine whether cooperative fund families are more likely to have intra-family coordinated trades, we estimate cross-trading as the dollar amount of all buy and sell trades of a particular stock that appear to be crossed within a family (Cross-trades). Using the equity holdings data from CRSP between 2004 and 2015, we identify those stocks that are purchased and sold by different funds in the same family in the same

\footnotetext{
${ }^{13}$ Eisele et al. (2017) find that the latter motivation only prevails before the late-trading scandal in 2003 when monitoring was weak and cross-trading decreases transaction costs when monitoring is strong.
} 
month and in the same quantity (the buy and sell volume of stock is exactly equal). ${ }^{14}$ We then aggregate up the dollar volume of these crossed trades to a quarterly level and divide by the total family equity trading volume. We also construct a "style-adjusted" version of our cross-trading measure where we further require that the exact tradecrossing occurs between two funds within the same investment objective to control for mechanical switches between styles (e.g., when a growth stock becomes a value stock).

We also use data on investment advisors contained in the uniform application for investment advisor registration (form ADV) similar to Casavecchia and Tiwari (2016). The SEC requires fund advisors to disclose their agency cross-trading practices. Using historical ADV data from 2001 to 2015, we collect investment advisory firms' answers to item 8, section B of the form. In agency cross-trading, an advisor (or its affiliated broker), acting as agent, arranges off-market transactions between different advisory clients or between a brokerage customer and an advisory client. Because this self-reported ADV measure is required disclosure by the SEC, it should be reasonably accurate and complete, avoiding the need to infer cross-trading from holdings or trade data. Moreover, Del Guercio, Genç, and Tran (2017) find a positive and significant correlation between the cross-trade measure from the ADV form and the Ancerno transaction-level data from Ben-Rephael and Israelsen (2015). The Agency cross-trading variable is the percentage of affirmative answers to questions 1 to 3 of Item 8, Section b.

Table 9 reports the cross-trading regression results. The first two columns report the results for our holdings-based cross-trading measures. The last column reports the results for our form ADV-based cross-trading measures. The same set of control variables used in previous regressions are included in the regression, but coefficients are omitted to accommodate the formatting of the table. Across all specifications, we find strong evidence that competitive incentives are associated with less cross-trading, while cooperative incentives are associated with more cross-trading. Looking at the most conservative holdings-based cross-trading measure, style-adjusted, we see that a one standard deviation increase in competitive incentives decreases cross-trading by $1.6 \%$, and a one standard deviation increase in cooperative incentives increases cross-trading by around $1.5 \%$.

\footnotetext{
${ }^{14}$ In this analysis, we use the CRSP holdings data, as opposed to Thompson, due to the higher percentage of funds reporting monthly. Requiring the buy/sell trade quantity to match exactly and using monthly as opposed to quarterly timing helps to more accurately identify cross-trading activity. We are grateful to an anonymous referee for this suggestion.
} 
[Insert Table 9 here]

\subsubsection{Cross-holding}

Bhattacharya, Lee, and Pool (2013) provide evidence of an alternative way in which coordination or cross-subsidization can take place within fund families. They show that fund families use their affiliated fund-of-mutual funds to provide liquidity to offset liquidity shortfalls of other funds in the family. This direct capital injection from one fund in the family to another fund that is facing large redemptions results in performance transfer from the supporting fund to the liquidity constrained fund. To determine whether there is a positive relation between cooperation within a family and the level of direct liquidity support in the form of funds holding other siblings in the family, we run a fund-level logistic regression to determine the likelihood of purchasing shares in another fund in the family in times of distress. We define distress as outflows larger than 5\% during the quarter.

The results of our cross-holding analysis are shown in Table 10. The independent variables of interest include a distress indicator, the incentive indices, and the interaction between the two in addition to the standard set of controls. The table reports odds ratios instead of coefficients. Looking first at distress, we see that if a fund is in distress (i.e., distress indicator $=1$ ), we see that the probability of being cross-held by another fund in the family increases by approximately $26 \%$. While we see no statistically significant effect of the incentive indices on average, for those funds in distress, a one unit increase in competitive (cooperative) incentives corresponds to a $9.1 \%$ decrease $(9.4 \%$ increase) in the probability of being cross-held. To ensure that these results are not driven mechanically by rebalancing on the part of the cross-holding fund, we repeat the analysis with investment objective-time fixed effects (Style ${ }^{*}$ Time) in the last three specifications. If the economic drivers underlying rebalancing decisions in balanced or asset allocation funds (e.g., a decrease in overall equity valuation relative to fixed income in early 2009 results in rebalancing toward equities) are correlated, investment objectivetime fixed effects will absorb this common rebalancing motive. Including these fixed effects, however, does not materially affect the results.

[Insert Table 10 here] 
While cross-trading and cross-holding are two prominent examples from the literature of coordinated behavior, there are a number of alternative measures of coordination. In Table A12 of the Internet Appendix, we also examine the relation between incentives and other proxies of coordinated behavior specifically focused on information sharing across the family. The first of these proxies (Cross assets trading) measures the ownership of stocks and bonds issued by the same corporation by stock and bond funds belonging to the same investment advisor. The second (Stock weight \% fund) and third (Stock weight \% assets) proxies measure ownership of the same stock across different funds of the same advisor. The last proxy (Adopt time) measures the speed of information diffusion within a family. Namely, when one fund in a family invests in a new stock, how quickly do other funds offered by the same advisor invest in the new security? Across these different measures, we would expect greater information sharing due to higher cooperative incentives to increase common ownership/overlap and decrease adoption time, and this is what we find.

Overall, we find strong evidence that cooperative incentives translate into coordinated action across the investment advisor. This evidence on coordinated action across funds in the family provides insight into potential mechanisms for the more stable cash flows that we observe in families with cooperative incentives.

\section{Fund family incentive structure: clientele and distribution channel}

While our analysis of performance, dispersion, and cash flow volatility gives additional insight into the strategic implications of an investment advisor's use of competitive or cooperative incentives, the choice between these different incentive mechanisms is not made in isolation and may be related to other aspects of the investment advisor's business. The literature points to two additional strategic dimensions that may complement the investment advisor's choice of incentive scheme: investor clientele and fund distribution channel.

Gârleanu and Pedersen (2018) model the equilibrium choice of investors to directly invest or to use an asset manager to invest on their behalf. They find that institutional investors (i.e., investors with lower search costs relative to their assets to be invested) benefit from searching for informed managers. Considering our results in the context of their model, we posit that competitive investment advisors are more likely to have 
institutional clients. If cross-subsidization and resource sharing across funds results in the transfer of performance, these activities have the potential to obscure the performance signal that institutional investors use to identify managers. In contrast, because managers in a competitive investment advisor are less willing to collaborate, the performance signal in these families would be clearer. Moreover, since institutional investors have lower search costs and greater ability to discern talented managers, the competitive compensation model would be more suitable for investment advisors hoping to attract institutional assets. At the same time, for retail investors who are less able to discern manager skill, as posited in the assumptions of their model, the greater dispersion in fund performance across funds managed by competitive advisors would result in greater investment risk.

Related to the clientele evidence above, Del Guercio and Reuter (2014) show that the market for retail funds is segmented, catering to two distinct clienteles based on the distribution channel. They find that investors who purchase funds sold through the broker channel are less sensitive to performance and appear less sophisticated in their investment decisions. Given our earlier evidence that funds from families with net cooperative incentives underperform, the family's decision to utilize cooperative incentives may be complemented by selling through a broker-distribution channel to access less sophisticated investors who have preferences over non-performance fund characteristics, whereas competitive fund families would be more likely to be direct sold funds.

To assess the possible relation between incentives, clientele, and distribution channel, we regress our proxies for clientele and distribution on the competition indices. The results are given in Table 11. As our measure of institutional clientele, we identify those investment advisors that manage both mutual funds and hedge funds using the sideby-side indicator employed by Del Guercio, Genç, and Tran (2017). To proxy for the distribution channel, we use the proportion of assets under management in the family that is sold without a load fee in a family.

While our previous analysis uses the competitive and cooperative indices as explanatory variables, in this specification the dependent variable is the average family index level of these incentives. ${ }^{15}$ As the results show, both direct distribution and institutional clientele, as proxied for by our side-by-side indicator variable, are associated with

\footnotetext{
${ }^{15}$ Because the side-by-side proxy for institutional clientele is only available for a subset of our sample, we analyze the institutional clientele and distribution channel results as separate specifications.
} 
stronger net competitive incentives both with or without family-level controls.

[Insert Table 11 here]

\section{Robustness}

While our results show a strong relation between family incentives and fund/family behavior, it is possible that these behaviors are being driven by an omitted variable, subject to simultaneous causality or some other source of endogeneity. To address these concerns, we use a quasi-experimental design focused on M\&A activity among advisors and a falsification test with random assignment of fund families as a whole. The M\&A setting provides a plausibly exogenous shock to the incentive structure of a fund, as target funds become subject to the incentives of the acquirer post-acquisition. In this setting, we revisit the fund-level mechanism evidence in Section 5. The falsification test, on the other hand, allows us to determine whether or not fund family-level outcomes and coordination behavior are mechanically driven by family structure and size.

\subsection{Investment advisor mergers and acquisitions}

We examine mergers and acquisitions in the asset management industry in a quasiexperimental design. ${ }^{16}$ Specifically, we use the difference in incentives between the acquirer and target family Net competitive index in the year before the merger as a plausibly exogenous shock to managerial incentives of target funds. We then examine how this shock to managerial incentives of the target fund relates to the active share, tracking error, cross-trading, and cross-holding of the fund. One important advantage of this setting is that the manager, investment strategy, and other fund characteristics are held constant across the acquisition date, so we can be more confident that any change in the fund-outcome variables is due to changes in the incentive environment.

\footnotetext{
${ }^{16}$ To identify possible investment advisor mergers, we examine two different sources. First, the NSAR filings require investment company registrants to identify "Changes in control" (question 77.H). We use an affirmative response to this item as a possible indicator of investment advisor merger. Second, the investment advisor registration statement (form ADV) identifies "Control persons" (Item 10). We identify the subset of form ADV registrants who manage discretionary assets (Part 1, Item 5.F.(2).(a)) and have investment company/mutual fund assets (Part 1, Item 5.D.(1-3).(d)). Within that subset, we then identify those investment advisors who have a change in their stated "Control persons" as a possible merger candidate. With possible mergers from these two sources, we then search newspapers, magazines, industry periodicals, press releases, and other popular media sources to confirm the merger and to identify the merger date.
} 
To eliminate any concern about possible ex-ante differences between the sample of acquired funds and those funds whose investment advisor is not acquired, we limit our analysis to acquired funds. Instead of the standard bivariate treatment/control framework commonly used in financial economics, we focus on variation in "dosing" across our treatment sample for identification. Because there is wide variation in the differences in incentives between acquiring and target investment advisors (i.e., competitive advisors acquire cooperative targets and vice versa), we include this difference in incentives as a continuous variable in our analysis. While the median difference in the net competitive incentive indices is 0.057 , indicating that, on average, the acquirer has more competitive incentives than the target, $37.1 \%$ of the target funds in our M\&A subsample have more competitive incentives than their acquirer before the acquisition, while $62.9 \%$ have more cooperative incentives. Additionally, we find that the difference in incentives between the acquirer and the target at $t-12$ is a strong predictor (coefficient of 0.824 with a $t$ statistic of over 10) of the change in incentives of the target fund from the month before the acquisition $(t-1)$ to 12 months after the acquisition $(t+12)$.

In Table 12 we show the results. The dependent variables are active share, tracking error, cross-trading, and cross-holdings. In addition to the standard fund and family controls, the specification also includes fund and time fixed effects absorbing any unobservable fund-specific effects or any time-series variation that may have otherwise affected our results. We include an indicator variable for the post-merger period (Post-event), and we interact the dosage variable, ( $\Delta$ Netcompetition) with this post-event period. Consistent with our previous results, Table 12 shows that an increase in net competitive incentives for acquired funds is associated with higher active share and tracking error, but a lower incidence of cross-trading and cross-holding post-acquisition. In addition to addressing concerns about alternative causality, the active share and tracking error results help to clarify the potential mechanism through which incentives affect family outcomes. In our earlier results, we cannot identify whether increased competitive incentives increase performance through higher manager effort or attracting superior managers. Because we are holding the manager constant across the acquisition period, the increase in active share and tracking error in Table 12 is due to increased manager effort in this subsample.

[Insert Table 12 here] 


\subsection{Placebo test: pseudo fund families}

In Table 2, we find that cooperative families are larger, on average, than competitive families. If larger families offer a greater number of funds across a greater number of investment objectives, one specific endogeneity concern is that our finding of more cross-trading or cross-holding is not necessarily due to the incentive structure in place but rather the family characteristics. To address this concern, we include the size of the families, the number of funds, and the number of stocks held as control variables in our regressions. As an additional robustness check to rule out that the results are mechanically driven by the size or structure of fund families, we run a falsification test.

For each family in each month, we create a control family with the same number of funds and the same structure in terms of size and investment style distribution by randomly selecting matched funds from other families. More precisely, a family with $\mathrm{N}$ funds each with a certain investment style and from a given fund size decile is matched to $\mathrm{N}$ funds outside the family from the same styles and fund size deciles on a random basis. Through this matching, this pseudo family has the same number of funds from the same investment objectives and very similar TNA managed as the original family. This way, we have plausibly kept the family characteristics the same, while randomizing on the competition and cooperation incentives, within the matched families. These pseudofamilies create a benchmark for our fund family coordination outcomes under the null of no cooperation or competition.

Table 13 shows the Fama-MacBeth (1973) estimation of the effect of competitive and cooperative incentives on pseudo fund family outcomes. While the robustness check in Table 12 focused on fund-level outcomes, the family-level nature of this analysis necessitates a focus on family-level outcomes. If cross-trading and cross-holding are not conscious decisions made by managers motivated by their incentives, but rather mechanically arise from simply being a large fund family, then we would expect to see that the pseudo families, constructed upon randomly assigned funds matched by style and size, exhibit similar levels of cross-subsidization. Similarly, the pseudo test helps to rule out that the large family structure mechanically influences our performance results.

However, as can be seen from the table in these random families, there seems to be no statistically significant evidence of family performance, dispersion, cross-trading, and cross-holding activity. The net competitive indices constructed across these randomly 
assigned family affiliations are not significantly related to these activities. These results suggest that our family-level outcome results are driven by incentives and coordination choices made at the family level and not spurious family characteristics.

[Insert Table 13 here]

\subsection{Additional robustness}

In addition to our M\&A and falsification tests, we also run a number of additional robustness checks to rule out specific endogeneity concerns. For example, the incentive structure of financial conglomerates might be different from specialized mutual funds. To show that our results are not driven by financial conglomerate ownership, we repeat our principal regressions controlling for ownership of an investment advisor by a financial conglomerate in Table A13 in the Internet Appendix. Net competitive incentives are similarly positively related to performance, dispersion, and effort and negatively related to cross-trades as in our main sample and do not seem to be affected by conglomerate ownership, as the interaction between the net competitive index and the conglomerative indicator variable is not statistically significant.

In Table A4 of the Internet Appendix, we show various sample splits to illustrate the results are not driven by certain family characteristics or by time period. Our results remain virtually unchanged when we run the main analysis on families with focused styles, large families only, and families with shrinking or growing assets. Our results persist among families with low or high fees and across the sample period 2005-2015 including and excluding the financial crisis.

In Table A5 in the Internet Appendix, we vary the construction of our three indices, cooperative, competitive, and net competitive, to show that our results are robust to the way we measure incentives. In Panel A of table A5 of the Internet Appendix, we construct our indices using only equity funds; Panel B creates the indices using a TNAweighted average of the fund characteristics as opposed to an equal weight; and in Panel $\mathrm{C}$ we give the individual subcomponents of the index equal weight. We rank components by investment objective to rule out differences in among fund families portfolio of fund styles driving the results (Panel D). In Panels E and F we run a principal components analysis (PCA) of the cooperative and competitive incentive index components. Using the first three components of each PCA analysis to construct the indices, we repeat the 
analysis with very similar results. Overall, the results suggest that our conclusions are not sensitive to how we construct the index.

\section{Conclusion}

Asset management is a highly competitive industry where human capital is the principal asset. Because that human capital can easily move from one firm to another, the compensation strategy to attract and retain fund managers is a key decision in operating a successful investment advisory firm. Given the dual goal of retaining good managers and maximizing fund performance, incentivizing fund managers to generate outperformance in the funds they manage may seem, on the surface, like a reasonable approach. Such incentives would generate competition among fund managers both within and outside the firm. At the same time, if the goal is maximizing the overall value of the investment advisor, encouraging cooperation among fund managers in the family may be a superior incentive scheme. Our analysis helps to identify the impact of these two different compensation approaches and the characteristics of investment advisors who choose cooperative or competitive incentive schemes.

We develop measures of the firm's cooperative and competitive incentives and find cross-sectional variation in the incentive structure of fund families, where some investment advisors have (net) competitive incentives, while other investment advisors have cooperative incentives. This distinction between competitive and cooperative incentives has important implications for fund managers. Families that have more cooperative incentives and labor markets are more likely to engage in coordination/cross-subsidization as measured by cross-holding and cross-trading and have more stable cash flows over time. Families that are more competitive in nature have higher fund performance and a higher fraction of star performers, but they have higher variation in performance among funds in the same family.

These two different incentive mechanisms are also associated with other aspects of firm strategy, namely distribution channel and clientele. Consistent with the insights of Gârleanu and Pedersen (2018), competitive advisors are more likely to manage institutional assets and have their funds distributed directly to investors. Cooperative families, on the other hand, are more likely to manage retail investor assets and to have their fund offerings marketed through a broker-distribution channel, consistent with investor 
demand for nonperformance characteristics.

When we repeat these analyses using investment advisor acquisitions as a shock to the incentive structure of acquired funds, we observe that funds acquired by advisors with more competitive incentives than they have previously experienced exhibit an increase in managerial effort and a decrease in cooperation. We also randomly assign families as a falsification test, and the results suggest our family-level outcomes do not arise mechanically from family characteristics.

In understanding what drives the distinction between families who choose cooperative incentives versus those who choose competitive incentives, the literature on "internal capital markets" provides an important framework. Thinking of an investment advisor as "the firm" and each fund manager as a "division manager," the mutual fund industry provides a unique setting in which to examine the workings of internal capital markets. Consistent with the insights of Williamson (1975) and Stein (1997) on the bright side of internal capital markets, cooperative incentives align fund manager incentives with those of the firm. Fund managers are willing to sacrifice the performance of their own fund to support other funds in the family that are of strategic importance. The overall result is greater cash flow stability. Our results are also consistent with the insights of Scharfstein and Stein (2000) and Rajan, Servaes, and Zingales (2000) on the dark side of internal capital markets. Competitive incentives appear to encourage individualistic fund/division manager behavior that is associated with greater dispersion in fund outcomes.

Our paper also adds an important insight to this internal capital markets literature. Across the different incentive mechanisms in Stein (1997), Scharfstein and Stein (2000), and Rajan, Servaes, and Zingales (2000), the overall surplus is split differently across the different parties, but the level or amount of that surplus is unchanged. We find that competitive incentives result in higher average performance consistent with either incentivizing greater effort on the part of managers or attracting managers with higher ability. While the lack of coordination between the objectives of these higher effort/higher skill managers and the investment advisor may still result in the dark side of internal capital markets, those negative effects must be weighed against higher overall performance in our context, or a larger overall surplus in the context of a more general internal capital markets literature. Overall, our paper yields important insights into the 
specific economics of the asset management industry and more general insights into the theory of the firm. 


\section{References}

Adams J. C. , T. Nishikawa, R. P. Rao, 2018. Mutual fund performance, management teams, and boards. Journal of Banking and Finance 92, 358-368.

Amihud, Y., Goyenko, R., 2013. Mutual fund's $R^{2}$ as predictor of performance. The Review of Financial Studies 26, 667-694.

Bar, M., Kempf A., and S. Ruenzi, 2011. Is a team different from the sum of its parts? Evidence from Mutual Fund Managers. Review of Finance 15, 359-396.

Ben-Rephael, A., R. D. Israelsen, 2015. Are some clients more equal than others? Evidence of price allocation by delegated portfolio managers. Review of Finance forthcoming.

Bhattacharya, U., Lee J. H, and V. K. Pool, 2013. Conflicting Family Values in Mutual Fund Families. The Journal of Finance 68, 173-200.

Bliss, R. T, Potter M.E., and C. Schwarz, 2008. Performance characteristics of individuallymanaged versus team-managed mutual funds. The Journal of Portfolio Management 34, $110-119$.

Brown, K. C., W. V. Harlow, and L. T. Starks, 1996. Of tournaments and temptations: an analysis of managerial incentives in the mutual fund industry. The Journal of Finance $51,85-110$.

Carhart, M. M., 1997. On persistence in mutual fund performance. The Journal of Finance $52,57-82$.

Casavecchia, L., Tiwari, A., 2016. Cross trading by investment advisers: implications for mutual fund performance. Journal of Financial Intermediation 25, 99-130.

Chevalier, J., and G. Ellison, 1997. Risk taking by mutual funds as a response to incentives. Journal of Political Economy 105, 1167-200.

Christoffersen, S. E. K. , R. B. Evans, and D. K. Musto, 2013. What do consumers' fund flows maximize? evidence from their brokers' incentives. The Journal of Finance 68, $201-235$.

Coles, J. L., J. Suay, and D. Woodbury, 2000. Fund advisor compensation in closed -end 
funds. The Journal of Finance 55, 1385-1414.

Cremers, K. J. M., and A. Petajisto, 2009. How active is your fund manager? A new measure that predicts performance. The Review of Financial Studies 22, 3329-3365.

Daniel, K., M. Grinblatt, S. Titman, and R. Wermers, 1997. Measuring mutual fund performance with characteristic-based benchmarks. The Journal of Finance 52, 1035-1058.

Del Guercio, D., Genç, E., and H. Tran, 2017. Playing favorites: conflicts of interest in mutual fund management. Journal of Financial Economics Forthcoming.

Del Guercio, D., and J. Reuter, 2014. Mutual fund performance and the incentive to generate alpha. The Journal of Finance 69, 1673-1704.

Eisele, A., T. Nefedova, G. Parise, and K. Peijnenburg, 2017. Are star funds really shining? Cross -trading and performance shifting in mutual fund families. Forthcoming Journal of Financial Economics.

Fama, E. F., and K. R. French 1992. The cross-section of expected stock returns. The Journal of Finance 47, 427-465.

Fama, E. F., and J. D. MacBeth, 1973. Risk, return and equilibrium: empirical tests. Journal of Political Economy 81, 607-636.

Farnsworth, H. and J. Taylor, 2006. Evidence on the compensation of portfolio managers. Journal of Financial Research 29, 305324.

Gârleanu, N. and L. H. Pedersen, 2018. Efficiently inefficient markets for assets and asset management. The Journal of Finance, 73 1663-1712.

Gaspar, J., Massa M., and P. Matos, 2006. Favoritism in mutual fund families? Evidence on strategic cross -fund subsidization. The Journal of Finance 61, 73-104.

Hann, R. N., Ogneva, M., O. Ozbas, 2013. Corporate diversification and the cost of capital. The Journal of Finance 68, 1961-1999.

Jensen, M. C., 1968. The performance of mutual funds in the period 1945-1964. The Journal of Finance 23, 389-416.

Kacperczyk, M., and A. Seru, 2015. Does firm organization matter? Evidence from centralized and decentralized mutual funds, Unpublished working paper. Imperial College. 
Kempf, A., and S. Ruenzi, 2007. Tournaments in mutual-fund families. The Review of Financial Studies 21, 1013-1036.

Khorana, A., Servaes H., and L. Wedge, 2007. Portfolio manager ownership and fund performance. Journal of Financial Economics 85, 179-204.

Kosovetsky, L., 2016. Whom do you trust? Investoradvisor relationships and mutual fund flows. The Review of Financial Studies, 29, 898-936.

Lee J. H., Trzcinka C., and S. Venkatesan, 2018. Do portfolio manager contracts contract portfolio management? Unpublished working paper. Ivey Business School.

Ma, L., Y. Tang, and J. Gómez, 2017. Portfolio manager compensation in the U.S. mutual fund industry, The Journal of Finance, forthcoming.

Massa, M., and R. Patgiri, 2009. Incentives and mutual fund performance: higher performance or just higher risk taking?, The Review Financial Studies 22, 1777-1815.

Massa, M., Reuter J., and E. Zitzewitz, 2010. When should firms share credit with employees? Evidence from anonymously managed mutual funds. Journal of Financial Economics 95, 400-424.

Newey, W., and K. D. West, 1987. A simple positive-definite heteroskedasticity and autocorrelation consistent covariance matrix. Econometrica 55, 703-708.

Patel S. and S. Sarkissian, 2017. To group or not to group? evidence from mutual fund databases. Journal of Financial and Quantitative Analysis 52, 1989-2021.

Prather, L.J. and K.L. Middleton, 2002. Are N+1 heads better than one?: The case of mutual fund managers, Journal of Economic Behavior \& Organization, 47, 103-120.

Rajan, R., Servaes H. , and L. Zingales, 2000. The cost of diversity: the diversification discount and inefficient investment. The Journal of Finance 55, 35-80.

Rau, H. A, 2015. The disposition effect in team investment decisions: experimental evidence. Journal of Banking \& Finance 61, 272-282.

Scharfstein, D.S., and J. C. Stein, 2000. The dark side of internal capital markets: divisional rent-seeking and inefficient investment. The Journal of Finance 55, 2537-2564.

Schwarz, C.G., 2011. Mutual fund tournaments: the sorting bias and new evidence. The 
Review of Financial Studies 25, 913-936.

Sialm, C., and T. M. Tham, 2016. Spillover effects in mutual fund companies. Management Science 62, 1472-1486.

Sirri, E. R. and Tufano, P., 1998. Costly search and mutual fund flows. The Journal of Finance 53, 1589-1622.

Stein, J. C., 1997. Internal capital markets and the competition for corporate resources. The Journal of Finance 52, 111-133.

Williamson, O.E., 1975. Markets and hierarchies: analysis and antitrust implications. Collier Macmillan Publishers, Inc., New York.

Zambrana, R., 2017. Asset Management and Financial Conglomerates: Attention through Stellar Portfolios. Unpublished working paper. Nova SBE. 


\section{Data appendix: Variable definitions}

\begin{tabular}{|c|c|}
\hline Variable & Definition \\
\hline \multicolumn{2}{|l|}{ Index variables } \\
\hline CIR measure & $\begin{array}{l}\text { Based on question } 48 \text { from the N-SAR, we take the difference between the last and first marginal compensation } \\
\text { rates divided by the effective marginal compensation rate (see Massa and Patgiri, 2009). }\end{array}$ \\
\hline Individual Fund & The proportion of funds within a family that are managed by an individual fund manager. \\
\hline Manager ownership & $\begin{array}{l}\text { Morningstar's ownership range based on the portfolio managers ownership data reported to the SEC. Portfolio } \\
\text { manager ownership falls in one of the following seven ranges: } \$ 0 \text { (none), } \$ 1-\$ 10,000, \$ 10,001-\$ 50,000, \$ 50,001 \text { - } \\
\$ 100,000, \$ 100,001-\$ 500,000, \$ 500,001-\$ 1,000,000 \text {, and above } \$ 1,000,000 \text {. }\end{array}$ \\
\hline Bonus-fund performance & $\begin{array}{l}\text { Manager-level compensation indicator variables from the fund's SAI filings of whether or not the manager's } \\
\text { compensation is based on the specific fund's performance. }\end{array}$ \\
\hline Bonus-paid in fund shares & $\begin{array}{l}\text { Manager-level compensation indicator variables from the fund's SAI filings of whether the manager compensation } \\
\text { includes shares from the fund. }\end{array}$ \\
\hline Bonus-fund revenue & $\begin{array}{l}\text { Manager-level compensation indicator variables from the fund's SAI filings of whether the manager compensation } \\
\text { is linked to the revenues collected by the fund. }\end{array}$ \\
\hline Other funds fee & $\begin{array}{l}\text { Fund advisory contract fee variable captures whether or not the fund's management fee is based on the assets, } \\
\text { income, or performance of other registrants (question } 52 \mathrm{~N} \text {-SAR) }\end{array}$ \\
\hline Team fund & The proportion of funds in a family managed by a team of managers. \\
\hline Manager connected & $\begin{array}{l}\text { This variable is defined as the number of funds that have managers in common with other funds in the family } \\
\text { divided by the total number of funds in the same investment objective in the family. }\end{array}$ \\
\hline Managers/Funds ratio & The average number of managers per fund in the family. \\
\hline Bonus-paid in advisor equity & $\begin{array}{l}\text { Manager-level compensation indicator variables from the fund's SAI filings of whether the manager has equity in } \\
\text { the advisor. }\end{array}$ \\
\hline Bonus-overall advisor revenue & $\begin{array}{l}\text { Manager-level compensation indicator variables from the fund's SAI filings of whether a manager's bonus is based } \\
\text { on the overall profitability of the advisor. }\end{array}$ \\
\hline \multicolumn{2}{|l|}{ Fund characteristics } \\
\hline Cash & The proportion of fund's asset invested in cash (in \%). \\
\hline Expense ratio & Total annual expenses and fees divided by year-end TNA (in \%). \\
\hline Front load & Maximum fund sales charge (in \%). \\
\hline Fund age & Natural logarithm of the number of years since the fund inception date. \\
\hline Fund flows & The net growth in fund assets beyond reinvested dividends (Sirri and Tufano, 1998) over the past one year. \\
\hline Fund ranking revenues & $\begin{array}{l}\text { Cross-sectional decile rank of fund's contribution to total fund family revenues. Revenues is calculated as assets } \\
\text { under management times fee. }\end{array}$ \\
\hline Fund size & Natural logarithm of TNA (total net assets) under management (in US $\$ \mathrm{~m}$ ). \\
\hline Fund turnover & Minimum of aggregate purchases and sales of securities divided by average TNA over the calendar year. \\
\hline Gross returns & Monthly portfolio gross return (in \%). \\
\hline Gross performance & Portfolio gross return minus the median value of the return of all the funds within the same investment objective. \\
\hline Manager tenure & Natural logarithm of the number of years since the fund manager started working for the fund family. \\
\hline Past return & The cumulative fund return, computed over a trailing 12-month window. \\
\hline \multicolumn{2}{|l|}{ Family characteristics } \\
\hline Competitive & A standardized index that measures the fund family competitive incentives. \\
\hline Competitive family & Indicator variables for families with above median competitive incentives scheme. \\
\hline Cooperative & A standardized index that measures the fund family cooperative incentives. \\
\hline Cooperative family & Indicator variables for families with above median cooperative incentives scheme. \\
\hline Cross-holding & The dollar amount of funds held by other funds in the family as a fraction of total assets managed by the firm. \\
\hline Fund cross-holding & The dollar amount of funds held by other funds in the family as a fraction of total assets managed by the fund. \\
\hline SEC form ADV Cross-trading & The percentage of affirmative answers to questions 1 to 3 of Section B of Item 8 form ADV. \\
\hline Holding-based cross-trades & $\begin{array}{l}\text { The dollar amount of all buy and sell trades of a particular stock that gets offset within a family in a given } \\
\text { quarter as a fraction of total family trading volume using the equity holdings data from CRSP between } 2010 \text { and } \\
\text { 2015. Then we take an equal-weighted average of this measure across all stocks in the entire family portfolio. }\end{array}$ \\
\hline Cross-trades (style adjusted) & $\begin{array}{l}\text { as the dollar amount of all buy and sell trades of a particular stock that gets offset within a family in a given } \\
\text { quarter as a fraction of total family trading volume using the equity holdings data from CRSP within investment } \\
\text { objective between } 2010 \text { and } 2015 \text {. Then we take an equal-weighted average of this measure across all stocks in } \\
\text { the entire family portfolio. }\end{array}$ \\
\hline Cross-asset trading & $\begin{array}{l}\text { We use the CRSP holdings data as of } 2010 \text { that has both equity and bond holdings information to construct a } \\
\text { variable that captures the average frequency in which both equity and bond funds simultaneously hold a security } \\
\text { of the same firm as a fraction of the total number of holdings in the asset management company. }\end{array}$ \\
\hline Stock weight $\%$ funds & $\begin{array}{l}\text { The average across all stocks in family of the number of portfolios holding a stock over the number of portfolios } \\
\text { in the family, with competitive incentives. }\end{array}$ \\
\hline Stock weight $\%$ assets & $\begin{array}{l}\text { A Herfindahl index of the fund family holdings; more precisely, its the sum of the squares of the portfolio holdings } \\
\text { within a fund family weighted by the total family holdings size. }\end{array}$ \\
\hline
\end{tabular}

Continued on next page 


\begin{tabular}{|c|c|}
\hline Variable & Definition \\
\hline Adopt time & $\begin{array}{l}\text { The average across funds in the family of the time lapsed in quarters between the initiation of the position (the } \\
\text { date the first fund in the family purchased the stock over the past year) and when other funds in the family also } \\
\text { purchased the stock. }\end{array}$ \\
\hline Family age & Natural logarithm of the number of years since the fund family issued the first fund. \\
\hline Family cash & The family average of fund's asset invested in cash. \\
\hline Family expense ratio & The family average of total funds expense ratio. \\
\hline Family front load & The family average of funds sales charges. \\
\hline Family funds & Natural logarithm of the number of funds within the fund family. \\
\hline Family gross return & The family average of fund before-fee returns. \\
\hline $\begin{array}{l}\text { Family performance (Gross Re- } \\
\text { turns) }\end{array}$ & $\begin{array}{l}\text { The family average of fund performance. Performance is measure with the gross return minus the median value } \\
\text { of the return of all the funds within the same investment objective. }\end{array}$ \\
\hline Family size & Natural logarithm of TNA of all funds in the family, excluding the fund itself. \\
\hline Family star funds & The total star funds in a family as a fraction of the total funds the family is currently managing. \\
\hline Family stocks & Natural logarithm of the number of stocks held within the fund family. \\
\hline Family turnover & The family average of individual fund turnover. \\
\hline Net competitive & A standardized index that measures the fund family net competitive (competitive - cooperative) incentives. \\
\hline Net competitive family & Indicator variables for families with above median net competitive incentives scheme. \\
\hline Performance dispersion & $\begin{array}{l}\text { The cross-sectional standard deviation of fund performance within all the funds managed by the family in a given } \\
\text { period. }\end{array}$ \\
\hline Direct distribution channel & Proportion of family $j$ assets under management from funds sold without a load fee. \\
\hline Side-by-side & An indicator variable for fund families that managed mutual funds and other pooled investment vehicles. \\
\hline \multicolumn{2}{|l|}{ Parent company characteristics } \\
\hline Family revenue volatility & $\begin{array}{l}\text { Is the time-series standard devation of a family aggregate advisory revenue using the past } 24 \text {-month observations. } \\
\text { Family advisory fee revenues are collected for each fund from their semiannual N-SAR filings and then aggregated } \\
\text { across all funds in the family. The dollar value of advisory revenue is then converted into a percentage using } \\
\text { lagged aggregate family assets as the denominator. }\end{array}$ \\
\hline Cash flow volatility & $\begin{array}{l}\text { The standard deviation of cash-flows of the parent company, using the past } 24 \text {-month observation. Cash-Flows } \\
\text { is the total cash standardized by lagged assets of the parent company. }\end{array}$ \\
\hline Parent age & The natural logarithm of the number of years since the parent company controlling the fund family was founded. \\
\hline Parent leverage & The total long-term debt of the parent company standardized by assets. \\
\hline Parent ROA & The income before extraordinary items of the parent company, as a proportion of lagged asset. \\
\hline ROA volatility & The standard deviation of return on assets of the parent company, using the past 24-month observation. \\
\hline
\end{tabular}




\section{Appendix: incentive indices construction example}

The data used in constructing the competition and cooperation indices comes from three different sources: Morningstar, the SAI, and the SEC semiannual report or NSAR. Both the competition and cooperation indices include data on whether a fund was solo or team managed, the number of managers of a fund, and the interconnectedness of managers across funds in a family. To construct these measures, we use the fund manager history data from Morningstar. The manager bonus, compensation, and fund ownership variables are given in the "Portfolio Managers" section of mutual funds' SAI , often under the heading "Compensation." From the N-SAR data, we collect both the advisory fee breakpoint data used to construct the Coles incentive rate as well as an indicator as to whether or not the advisory fee was based on the performance, assets, or income of other funds in the family. To clarify how the components of our cooperation and competition indices are calculated, we discuss in detail below the 2006 raw data and how they were coded for the Janus Fund. In every case, yes responses are coded as 1 , no responses as 0 .

At the end of 2005, Blaine Rollins was the sole manager of the Janus Fund. At that time, Morningstar classified the Janus Fund as large-cap growth, and Janus had 12 other funds that Morningstar classified as large-cap growth. Michael served as the manager of two of those funds. With this information, the raw value of the manager team variables are as follows:

- Individual fund: Yes

- Team fund: No

- Managers/Fund ratio: 1

- Manager connected: 2/12

As for the manager compensation variables, the February 26, 2006, Janus SAI describes the determinants of the manager's compensation and bonus as follows:

"A portfolio manager is compensated for managing a Fundthrough two components: fixed compensation and variable compensation .... Fixed com- 
pensation is paid in cash and is comprised of an annual base salary and an additional amount calculated based on factors such as the complexity of managing funds and other accounts, the scope of responsibility (including assets under management), tenure, and long-term performance as a portfolio manager... Variable compensation is paid in the form of cash and longterm incentive awards (consisting of Janus Capital Group Inc. ("JCGI") restricted stock, stock options, and a cash deferred award that is credited with income, gains, and losses based on the performance of Janus mutual fund investments selected by the portfolio manager).... Variable compensation is structured to pay the portfolio manager primarily on individual performance (and leadership criteria, as applicable), with additional compensation available for team performance and a lesser component based on net asset flows in the Managed Funds. A portfolio manager's individual performance compensation is determined by applying a multiplier against the portfolio manager's fixed compensation. The multiplier is tied to the Managed Funds' aggregate asset-weighted Lipper peer group performance ranking for one- and three-year performance periods, if applicable, with a greater emphasis on three-year results. The portfolio manager is also eligible to receive additional individual performance compensation if the Managed Funds achieve a certain rank in their Lipper peer performance groups in each of three, four, or five consecutive years (performance periods may be from the commencement of a portfolio manager's tenure managing a Fund). Equity portfolio manager compensation is also subject to reduction in the event that the Managed Funds incur material negative absolute performance. Portfolio managers are not eligible to earn any individual performance compensation if the Managed Funds' performance does not meet or exceed a certain ranking in their Lipper peer performance group."

The SAI also discloses Rollin's ownership of the Janus Fund as of October 31, 2005, as being over $\$ 1,000,000$. Based on this information, we coded the manager bonus or compensation variables as follows:

- Bonus based on fund performance: Yes 
- Bonus paid in fund shares: No

- Bonus based on fund revenue: Yes

- Bonus based on advisor-level determinants: No

- Bonus paid in advisor equity: Yes

- Manager ownership:> $\$ 1,000,000$

It is important to note that our bonus based on advisor-level determinants variable differs from the Ma, Tang, and Gomez (2018) advisor profitability variable. While many investment advisors indicate that the size of their bonus pool depends on the overall profitability of the advisor, our advisor-level determinants variables focus instead on the use of manager level effort/activity, as it relates to advisor-level activities being used to determine a bonus. While the variable is coded as "No" in this example, consider the following excerpt on compensation in Alliance Bernstein's March 1, 2006, SAI to help clarify this point:

"The Advisor's overall profitability determines the total amount of incentive compensation available to investment professionals. [Advisor-level profitability] ... In evaluating this component of an investment professional's compensation, the Advisor considers the contribution to his/her team or discipline as it relates to that team's overall contribution to the long-term investment success, business results, and strategy of the Advisor. [Advisor-level determinants].... There are no specific formulas used to determine this part of an investment professional's compensation and the compensation is not tied to any pre-determined or specified level of performance."

The SAI excerpt notes two separate things here. First, the size of the overall bonus pool may be affected by the performance of the advisor. Second, an individual manager's bonus is determined, in part, by their overall contribution to the long-term success, business results, and strategy of the advisor. It is possible that in a given year the pool might shrink, but if the managers contribution is large enough, that managers bonus might grow. When we code this variable, we are looking explicitly for the latter; namely, 
the advisor uses advisor-wide (as opposed to fund-specific) manager contributions as a determinant for the specific bonus of a given manager.

Last of all, the advisory fee breakpoints necessary to calculate the Coles incentive rate (CIR measure) and the indication of whether or not the fund's advisory fee was based entirely or partially on the performance, assets, and income of other funds in the family (Other funds fee) are both collected from the fund's semiannual report or N-SAR. The advisory fee breakpoints are given in question 48 of the N-SAR form, and the dependence of each fund's advisory fee on the performance, assets, and income of other funds in the family is given in question 52. In May 30, 2006, N-SAR filed on June 29, 2006, we see that the fund has no breakpoints, just an effective advisory fee rate of $0.64 \%$, across all fund sizes. With a perfectly linear advisory fee, the Coles incentive rate or CIR is zero. Additionally, the Janus Fund's advisory fee is not based on the performance, assets, or income of other funds in the family.

- CIR measure: 0

- Other funds fee: No

With the raw data in hand, we average these variables across all funds in the family and then calculate decile ranks for the family relative to other families in the cross-section (i.e., in the same time period). We then calculate an equal-weighted average of these ranks across all funds in the family to get a family average cooperation, competition, and net competition measure. For 2006, below are the Janus family decile ranks across variables:

- Individual fund: 5th decile

- Team fund: 5th decile

- Managers/Fund ratio: 3rd decile

- Manager connected: 2nd decile

- Manager bonus (based on performance): 4th decile

- Compensation in fund shares: 1st decile 
- Compensation based on fund revenues: 9th decile

- Compensation based on overall advisor profits: 1st decile

- Equity in advisor: 5th decile

- Manager ownership: 7th decile

- CIR measure: 5th decile

- Other funds fee: 1 st decile 


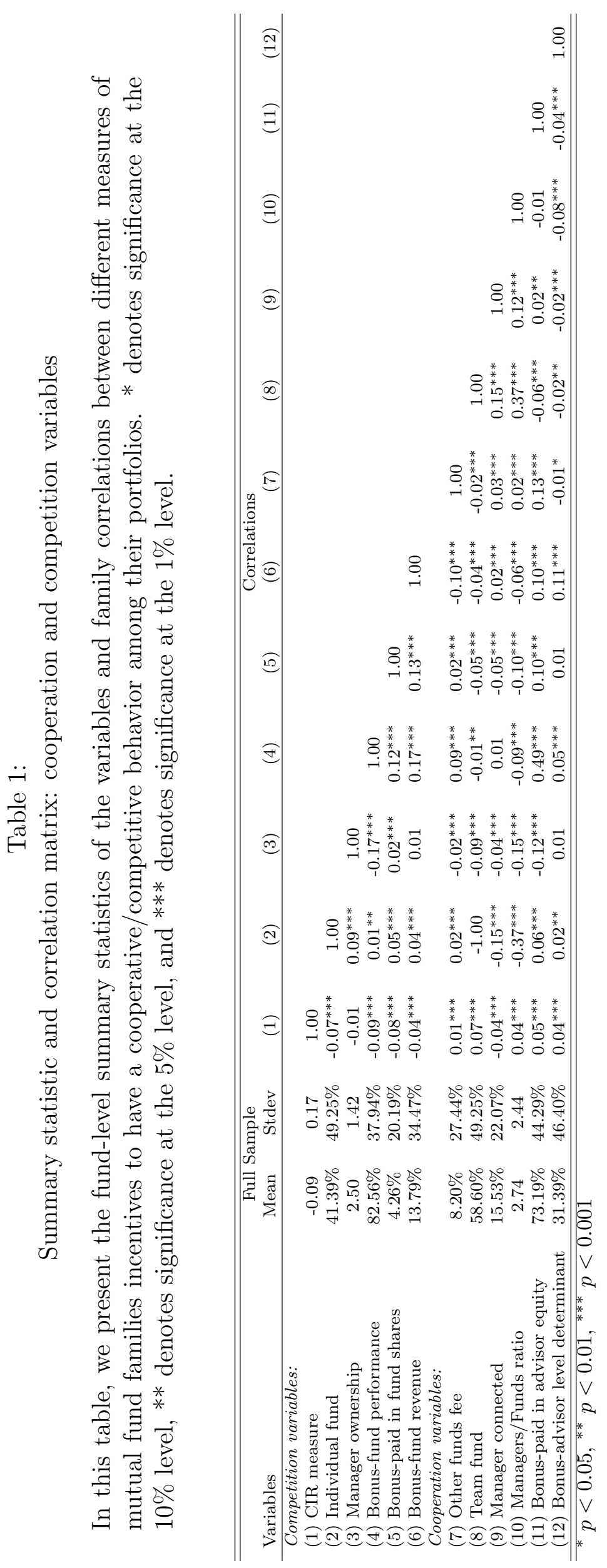


Table 2:

Competition vs Cooperation

This table presents the mean of fund and family characteristics, according to the family incentives to cooperate and compete, and the corresponding difference between the two samples. Funds are classified as being in a competitive or cooperative family if their families score above or below the median net competition index value. Standard errors are clustered at the fund family level. ${ }^{*}$ denotes significance at the $10 \%$ level, ${ }^{* *}$ denotes significance at the 5\% level, and *** denotes significance at the $1 \%$ level. Panel A contains all the variables at the fund level, and Panel B summarizes the characteristics for the whole family. Variable definitions are in Table 1 in the Appendix. The data cover the period 1992 to 2015.

\begin{tabular}{lccc}
\hline \hline & \multicolumn{3}{c}{ Panel A: Fund characteristics } \\
& Competitive & Cooperative & Difference \\
\hline Fund size (log TNA) & 4.981 & 5.682 & $-0.701^{* * *}$ \\
Fund age & 9.525 & 8.933 & $0.592^{* * *}$ \\
Gross returns & 0.702 & 0.659 & $0.043^{* * *}$ \\
Front load & 0.558 & 0.625 & $-0.067^{* * *}$ \\
Cash & 5.667 & 4.741 & $0.925^{* * *}$ \\
Expense ratio (\%) & 1.311 & 1.170 & $0.141^{* * *}$ \\
Fund turnover & 0.877 & 1.007 & $-0.130^{* * *}$ \\
Gross performance & 0.020 & 0.007 & $0.013^{* *}$ \\
Net performance & 0.007 & 0.006 & 0.001 \\
Fund flows (monthly) & 0.161 & 1.253 & -1.092 \\
Fund ranking revenues & 5.509 & 5.537 & $-0.027^{* * *}$ \\
\hline Average total funds & \multicolumn{3}{c}{} \\
\hline \hline & \multicolumn{3}{c}{ Panel B: Family characteristics } \\
& Competitive & Cooperative & Difference \\
\hline Family size (log TNA) & 6.749 & 9.592 & $-2.842^{* * *}$ \\
Family funds (log) & 1.538 & 2.587 & $-1.050^{* * *}$ \\
Family age (log) & 5.202 & 5.857 & $-0.655^{* * *}$ \\
Family stocks (log) & 5.564 & 7.149 & $-1.585^{* * *}$ \\
Family cash & 5.818 & 4.877 & $0.941^{* * *}$ \\
Family expense Ratio & 1.373 & 1.191 & $0.182^{* * *}$ \\
Family turnover & 0.872 & 0.991 & $-0.119^{* * *}$ \\
Family front load & 0.506 & 0.621 & $-0.115^{* * *}$ \\
Family star funds & 0.078 & 0.047 & $0.031^{* * *}$ \\
\hline Average total advisors & 312 & 239 & \\
\hline \hline
\end{tabular}


Table 3:

Fund Performance: Gross Returns

The table lists the results of following regression specification: FundPer formance f $_{i, t}=$ $\beta_{0}+\beta_{1}$ Competitive/Cooperative $_{j, t}+$ controls $+\epsilon_{i, t}$, where FundPer formance ${ }_{i, t}$ measures the performance of fund $i$ at time $t$ using the objective-adjusted gross returns (before fees). Competitive/Cooperative ${ }_{j, t}$ is a standardized index that measures the fund family $j$ competitive and cooperative incentives at time $t$. We also include the Net competitive (competitive - cooperative) effect. Variable definitions are the Data Appendix. The constant term is included but not reported. We estimate the above model by using the Fama-MacBeth (1973) method. The constant term is included but not reported. The $t$-statistics adjusted for serial correlation using Newey-West (1987) are reported in parentheses. $*$ denotes significance at the $10 \%$ level, ${ }^{* *}$ denotes significance at the $5 \%$ level, and ${ }^{* * *}$ denotes significance at the $1 \%$ level.

\begin{tabular}{|c|c|c|c|c|c|c|}
\hline \multirow[b]{2}{*}{ Competitive } & \multicolumn{6}{|c|}{ Gross performance } \\
\hline & $\begin{array}{c}0.019^{* * *} \\
(4.19)\end{array}$ & $\begin{array}{c}0.017^{* * *} \\
(3.99)\end{array}$ & & & & \\
\hline Cooperative & & & $\begin{array}{c}-0.011^{* * *} \\
(-2.60)\end{array}$ & $\begin{array}{c}-0.011^{* * *} \\
(-2.77)\end{array}$ & & \\
\hline Net competitive & & & & & $\begin{array}{c}0.019^{* * *} \\
(3.69)\end{array}$ & $\begin{array}{c}0.018^{* * *} \\
(3.69)\end{array}$ \\
\hline Family size (log TNA) & $\begin{array}{c}0.008^{* * *} \\
(3.75)\end{array}$ & $\begin{array}{c}0.009^{* * *} \\
(2.71)\end{array}$ & $\begin{array}{c}0.007^{* * *} \\
(3.32)\end{array}$ & $\begin{array}{c}0.008^{* *} \\
(2.54)\end{array}$ & $\begin{array}{c}0.008^{* * *} \\
(4.23)\end{array}$ & $\begin{array}{c}0.010^{* * *} \\
(3.06)\end{array}$ \\
\hline Family funds (log) & $\begin{array}{l}0.005 \\
(0.70)\end{array}$ & $\begin{array}{l}0.003 \\
(0.46)\end{array}$ & $\begin{array}{l}0.006 \\
(0.84)\end{array}$ & $\begin{array}{l}0.004 \\
(0.62)\end{array}$ & $\begin{array}{l}0.006 \\
(0.80)\end{array}$ & $\begin{array}{l}0.004 \\
(0.56)\end{array}$ \\
\hline Fund size (log TNA) & & $\begin{array}{l}0.004 \\
(0.68)\end{array}$ & & $\begin{array}{l}0.003 \\
(0.60)\end{array}$ & & $\begin{array}{l}0.003 \\
(0.62)\end{array}$ \\
\hline Expense ratio (\%) & & $\begin{array}{l}0.028 \\
(1.32)\end{array}$ & & $\begin{array}{l}0.029 \\
(1.33)\end{array}$ & & $\begin{array}{l}0.028 \\
(1.30)\end{array}$ \\
\hline Fund turnover & & $\begin{array}{l}0.012 \\
(0.80)\end{array}$ & & $\begin{array}{l}0.012 \\
(0.80)\end{array}$ & & $\begin{array}{l}0.012 \\
(0.81)\end{array}$ \\
\hline Fund flows (monthly) & & $\begin{array}{c}0.337^{* * *} \\
(6.83)\end{array}$ & & $\begin{array}{c}0.336^{* * *} \\
(6.84)\end{array}$ & & $\begin{array}{c}0.336^{* * *} \\
(6.84)\end{array}$ \\
\hline Fund age & & $\begin{array}{c}-0.012^{* *} \\
(-2.14)\end{array}$ & & $\begin{array}{c}-0.011^{* *} \\
(-2.08)\end{array}$ & & $\begin{array}{c}-0.012^{* *} \\
(-2.15)\end{array}$ \\
\hline Style dummies & $Y$ & $\mathrm{Y}$ & $\mathrm{Y}$ & $\mathrm{Y}$ & $\mathrm{Y}$ & $\mathrm{Y}$ \\
\hline No. of observations & $1,015,665$ & $1,006,554$ & $1,015,665$ & $1,006,554$ & $1,015,665$ & $1,006,554$ \\
\hline Adjusted $R^{2}$ & 0.005 & 0.023 & 0.005 & 0.023 & 0.005 & 0.023 \\
\hline
\end{tabular}


Table 4:

Family star funds

The table lists the results of following regression specification: FamStarFunds ${ }_{j, t}=$ $\beta_{0}+\beta_{1}$ Competitive/Cooperative $_{j, t}+$ controls $+\epsilon_{j, t}$, where FamStarFunds $s_{j, t}$ is the proportion of star funds in family $j$ at time $t$. Competitive/Cooperative ${ }_{j, t}$ is a standardized index that measures the fund family $j$ competitive and cooperative incentives at time $t$. We also include the Net competitive (competitive - cooperative) effect. Variable definitions are the Data Appendix. We estimate the above model by using the Fama-MacBeth (1973) method. The constant term is included but not reported. The $t$-statistics adjusted for serial correlation using Newey-West (1987) are reported in parentheses. denotes significance at the $10 \%$ level, $* *$ denotes significance at the $5 \%$ level, and *** denotes significance at the $1 \%$ level.

\begin{tabular}{|c|c|c|c|c|c|c|}
\hline \multirow[b]{2}{*}{ Competitive } & \multicolumn{6}{|c|}{ Star funds strategy } \\
\hline & $\begin{array}{c}0.019^{* * *} \\
(14.70)\end{array}$ & $\begin{array}{c}0.017^{* * *} \\
(13.66)\end{array}$ & & & & \\
\hline Cooperative & & & $\begin{array}{c}-0.015^{* * *} \\
(-8.34)\end{array}$ & $\begin{array}{c}-0.015^{* * *} \\
(-8.86)\end{array}$ & & \\
\hline Net competitive & & & & & $\begin{array}{c}0.021^{* * *} \\
(12.60)\end{array}$ & $\begin{array}{c}0.019^{* * *} \\
(12.33)\end{array}$ \\
\hline Family size (log TNA) & $\begin{array}{c}0.011^{* * *} \\
(11.19)\end{array}$ & $\begin{array}{c}0.020^{* * *} \\
(17.01)\end{array}$ & $\begin{array}{c}0.011^{* * *} \\
(10.32)\end{array}$ & $\begin{array}{c}0.021^{* * *} \\
(16.40)\end{array}$ & $\begin{array}{c}0.011^{* * *} \\
(11.08)\end{array}$ & $\begin{array}{c}0.021^{* * * *} \\
(16.85)\end{array}$ \\
\hline Family funds (log) & $\begin{array}{c}-0.024^{* * *} \\
(-7.55)\end{array}$ & $\begin{array}{c}-0.026^{* * *} \\
(-9.11)\end{array}$ & $\begin{array}{c}-0.025^{* * *} \\
(-7.75)\end{array}$ & $\begin{array}{c}-0.025^{* * *} \\
(-9.13)\end{array}$ & $\begin{array}{c}-0.023^{* * *} \\
(-7.45)\end{array}$ & $\begin{array}{c}-0.024^{* * *} \\
(-8.92)\end{array}$ \\
\hline Family age $(\log )$ & & $\begin{array}{c}-0.023^{* * *} \\
(-14.97)\end{array}$ & & $\begin{array}{c}-0.025^{* * *} \\
(-15.92)\end{array}$ & & $\begin{array}{c}-0.025^{* * *} \\
(-15.73)\end{array}$ \\
\hline Family cash & & $\begin{array}{c}0.001^{* * *} \\
(5.67)\end{array}$ & & $\begin{array}{c}0.002^{* * *} \\
(5.92)\end{array}$ & & $\begin{array}{c}0.001^{* * *} \\
(5.65)\end{array}$ \\
\hline Family expense ratio & & $\begin{array}{c}0.049^{* * *} \\
(15.40)\end{array}$ & & $\begin{array}{c}0.049^{* * *} \\
(15.00)\end{array}$ & & $\begin{array}{c}0.048^{* * *} \\
(14.74)\end{array}$ \\
\hline Family turnover & & $\begin{array}{c}0.006^{* *} \\
(2.40)\end{array}$ & & $\begin{array}{c}0.005^{* *} \\
(2.05)\end{array}$ & & $\begin{array}{c}0.005^{* *} \\
(2.27)\end{array}$ \\
\hline Family front load & & $\begin{array}{c}-0.027^{* * *} \\
(-9.79)\end{array}$ & & $\begin{array}{c}-0.030^{* * *} \\
(-10.72)\end{array}$ & & $\begin{array}{c}-0.028^{* * *} \\
(-10.09)\end{array}$ \\
\hline Family gross return & & $\begin{array}{c}0.353^{* * *} \\
(2.87)\end{array}$ & & $\begin{array}{c}0.367^{* * *} \\
(2.99)\end{array}$ & & $\begin{array}{c}0.358^{* * *} \\
(2.92)\end{array}$ \\
\hline No. of observations & 105,435 & 105,299 & 105,435 & 105,299 & 105,435 & 105,299 \\
\hline Adjusted $R^{2}$ & 0.022 & 0.076 & 0.019 & 0.075 & 0.022 & 0.077 \\
\hline
\end{tabular}


Table 5:

Performance dispersion

The table lists the results of following regression specification: $\operatorname{PerfDisp} p_{j, t}=$ $\beta_{0}+\beta_{1}$ Competitive/Cooperative $_{j, t}+$ controls $+\epsilon_{j, t}$, where PerfDisp p $_{j, t}$ is the crosssectional standard deviation of objective-adjusted fund returns of family $j$ at time $t$. Competitive/Cooperative $_{j, t}$ is a standardized index that measures the fund family $j$ competitive and cooperative incentives at time $t$. We also include the Net competitive (competitive - cooperative) effect. Variable definitions are the Data Appendix. We estimate the above model by using the Fama-MacBeth (1973) method. The $t$-statistics adjusted for serial correlation using Newey-West (1987) are reported in parentheses. denotes significance at the $10 \%$ level, ** denotes significance at the $5 \%$ level, and *** denotes significance at the $1 \%$ level.

\begin{tabular}{|c|c|c|c|c|c|c|}
\hline \multirow[b]{2}{*}{ Competitive } & \multicolumn{6}{|c|}{ Family performance dispersion } \\
\hline & $\begin{array}{c}0.055^{* * *} \\
(9.27)\end{array}$ & $\begin{array}{c}0.031^{* * *} \\
(5.53)\end{array}$ & & & & \\
\hline Cooperative & & & $\begin{array}{c}-0.040^{* * *} \\
(-10.07)\end{array}$ & $\begin{array}{c}-0.030^{* * *} \\
(-5.99)\end{array}$ & & \\
\hline Net competitive & & & & & $\begin{array}{c}0.061^{* * *} \\
(11.35)\end{array}$ & $\begin{array}{c}0.039^{* * *} \\
(6.49)\end{array}$ \\
\hline Family size (log TNA) & $\begin{array}{c}-0.014^{* * *} \\
(-3.88)\end{array}$ & $\begin{array}{c}0.027^{* * *} \\
(6.05)\end{array}$ & $\begin{array}{c}-0.014^{* * *} \\
(-3.58)\end{array}$ & $\begin{array}{c}0.030^{* * *} \\
(6.37)\end{array}$ & $\begin{array}{c}-0.012^{* * *} \\
(-3.21)\end{array}$ & $\begin{array}{c}0.030^{* * *} \\
(6.37)\end{array}$ \\
\hline Family funds (log) & $\begin{array}{c}0.090^{* * * *} \\
(8.19)\end{array}$ & $\begin{array}{c}0.041^{* * *} \\
(6.83)\end{array}$ & $\begin{array}{c}0.088^{* * *} \\
(8.05)\end{array}$ & $\begin{array}{c}0.040^{* * *} \\
(6.87)\end{array}$ & $\begin{array}{c}0.093^{* * *} \\
(8.62)\end{array}$ & $\begin{array}{c}0.043^{* * *} \\
(7.49)\end{array}$ \\
\hline Family age $(\log )$ & & $\begin{array}{c}0.021^{* *} \\
(2.39)\end{array}$ & & $\begin{array}{c}0.016^{*} \\
(1.80)\end{array}$ & & $\begin{array}{c}0.018^{* *} \\
(2.02)\end{array}$ \\
\hline Family cash & & $\begin{array}{c}0.007^{* * *} \\
(6.88)\end{array}$ & & $\begin{array}{c}0.007^{* * *} \\
(7.17)\end{array}$ & & $\begin{array}{c}0.007^{* * *} \\
(6.96)\end{array}$ \\
\hline Family expense ratio & & $\begin{array}{c}0.493^{* * *} \\
(23.37)\end{array}$ & & $\begin{array}{c}0.499^{* * * *} \\
(23.47)\end{array}$ & & $\begin{array}{c}0.494^{* * *} \\
(23.47)\end{array}$ \\
\hline Family turnover & & $\begin{array}{c}0.116^{* * *} \\
(9.06)\end{array}$ & & $\begin{array}{c}0.116^{* * *} \\
(9.04)\end{array}$ & & $\begin{array}{c}0.117^{* * *} \\
(9.15)\end{array}$ \\
\hline Family front load & & $\begin{array}{c}-0.119^{* * *} \\
(-11.02)\end{array}$ & & $\begin{array}{c}-0.124^{* * *} \\
(-11.64)\end{array}$ & & $\begin{array}{c}-0.121^{* * *} \\
(-11.33)\end{array}$ \\
\hline Family gross return & & $\begin{array}{l}1.210^{*} \\
(1.74)\end{array}$ & & $\begin{array}{l}1.208^{*} \\
(1.74)\end{array}$ & & $\begin{array}{l}1.204^{*} \\
(1.74)\end{array}$ \\
\hline No. of observations & 86,333 & 86,209 & 86,333 & 86,209 & 86,333 & 86,209 \\
\hline Adjusted $R^{2}$ & 0.011 & 0.145 & 0.008 & 0.144 & 0.011 & 0.145 \\
\hline
\end{tabular}


Table 6:

Family advisory revenue volatility

The table lists the results of following regression specification: $\operatorname{RevSt}_{j, t}=\beta_{0}+$ $\beta_{1}$ Competitive/Cooperative $_{j, t}+$ controls $+\epsilon_{j, t}$, where RevStd ${ }_{j, t}$ is the time-series standard deviation of family $j$ aggregate advisory revenues at time $t$, using the past 24-month observation. Family advisory fee revenues are collected for each fund from their semiannual N-SAR filings and then aggregated across all funds in the family. The dollar value of advisory revenue is then converted into a percentage using lagged aggregate family assets as the denominator and multiply by 100. Competitive/Cooperative Cot $_{j}$ is a standardized index that measures the fund family $j$ competitive and cooperative incentives at time $t$. We also include the Net competitive (competitive - cooperative) effect. Variable definitions are the Data Appendix. We estimate the above model by using the Fama-MacBeth (1973) method. The $t$-statistics adjusted for serial correlation using Newey-West (1987) are reported in parentheses. * denotes significance at the $10 \%$ level, $* *$ denotes significance at the $5 \%$ level, and $* * *$ denotes significance at the $1 \%$ level.

\begin{tabular}{|c|c|c|c|c|c|c|}
\hline \multirow[b]{2}{*}{ Competitive } & \multicolumn{6}{|c|}{ Family revenue volatility } \\
\hline & $\begin{array}{c}0.103^{* * *} \\
(9.83)\end{array}$ & $\begin{array}{c}0.034^{* * *} \\
(5.87)\end{array}$ & & & & \\
\hline Cooperative & & & $\begin{array}{c}-0.084^{* * *} \\
(-13.73)\end{array}$ & $\begin{array}{c}-0.018^{* * *} \\
(-3.38)\end{array}$ & & \\
\hline Net competitive & & & & & $\begin{array}{c}0.057^{* * *} \\
(8.91)\end{array}$ & $\begin{array}{c}0.018^{* * *} \\
(5.26)\end{array}$ \\
\hline Family size & & $\begin{array}{c}-0.002^{*} \\
(-1.87)\end{array}$ & & $\begin{array}{c}-0.003^{*} \\
(-1.89)\end{array}$ & & $\begin{array}{l}-0.002 \\
(-1.60)\end{array}$ \\
\hline Family funds & & $\begin{array}{c}-0.011^{* * *} \\
(-3.08)\end{array}$ & & $\begin{array}{c}-0.010^{* * *} \\
(-2.91)\end{array}$ & & $\begin{array}{c}-0.011^{* * *} \\
(-3.01)\end{array}$ \\
\hline Family age (log) & & $\begin{array}{c}-0.013^{* * *} \\
(-8.91)\end{array}$ & & $\begin{array}{c}-0.015^{* * *} \\
(-10.94)\end{array}$ & & $\begin{array}{c}-0.014^{* * *} \\
(-10.00)\end{array}$ \\
\hline Family cash & & $\begin{array}{l}-0.000 \\
(-1.30)\end{array}$ & & $\begin{array}{l}-0.000 \\
(-0.87)\end{array}$ & & $\begin{array}{l}-0.000 \\
(-1.06)\end{array}$ \\
\hline Family turnover & & $\begin{array}{c}0.000^{* * *} \\
(5.07)\end{array}$ & & $\begin{array}{c}0.000^{* * *} \\
(6.36)\end{array}$ & & $\begin{array}{c}0.000^{* * *} \\
(6.24)\end{array}$ \\
\hline Family front load & & $\begin{array}{c}0.005^{* *} \\
(2.58)\end{array}$ & & $\begin{array}{c}0.005^{* *} \\
(2.36)\end{array}$ & & $\begin{array}{c}0.005^{* *} \\
(2.43)\end{array}$ \\
\hline Family gross return & & $\begin{array}{l}-0.000 \\
(-1.02)\end{array}$ & & $\begin{array}{l}-0.000 \\
(-1.00) \\
\end{array}$ & & $\begin{array}{l}-0.000 \\
(-1.01) \\
\end{array}$ \\
\hline No. of observations & 67,704 & 66,607 & 67,704 & 66,607 & 67,704 & 66,607 \\
\hline Adjusted $R^{2}$ & 0.032 & 0.134 & 0.019 & 0.133 & 0.038 & 0.135 \\
\hline
\end{tabular}


Table 7:

Cash flow and return on assets volatility

The table lists the results of following regression specification: Instability $_{i, t}=\beta_{0}+$ $\beta_{1}$ Competitive/Cooperative $_{j, t}+$ controls $+\epsilon_{i, t}$, where Instability $_{i, t}$ measures the volatility of cash flows, and return on assets of the publicly traded firm $i$ at time $t$. Firm $i$ is the controlling company of fund advisor $j$. Volatility is calculated using the standard deviation of the past 24 months. Competitive/Cooperative ${ }_{j, t}$ is a standardized index that measures the fund family $j$ competitive and cooperative incentives at time $t$. We also include the Net competitive (competitive - cooperative) effect. Variable definitions are the Data Appendix. We estimate the above model by using the Fama-MacBeth (1973) method. The constant term is included but not reported. The $t$-statistics adjusted for serial correlation using Newey-West (1987) are reported in parentheses. denotes significance at the $10 \%$ level, ${ }^{* *}$ denotes significance at the $5 \%$ level, and $* * *$ denotes significance at the $1 \%$ level.

\begin{tabular}{|c|c|c|c|c|c|c|}
\hline \multirow[b]{2}{*}{ Competitive } & \multicolumn{3}{|c|}{ Cash flows volatility } & \multicolumn{3}{|c|}{ Return on assets volatility } \\
\hline & $\begin{array}{c}0.008^{* * *} \\
(2.79)\end{array}$ & & & $\begin{array}{c}0.165^{* * *} \\
(2.84)\end{array}$ & & \\
\hline Cooperative & & $\begin{array}{c}-0.005^{* * *} \\
(-4.34)\end{array}$ & & & $\begin{array}{c}-0.104^{* * *} \\
(-4.77)\end{array}$ & \\
\hline Net competitive & & & $\begin{array}{c}0.010^{* * *} \\
(3.44)\end{array}$ & & & $\begin{array}{c}0.213^{* * *} \\
(3.58)\end{array}$ \\
\hline Family size (log TNA) & $\begin{array}{l}0.000 \\
(0.89)\end{array}$ & $\begin{array}{l}0.001^{*} \\
(1.77)\end{array}$ & $\begin{array}{l}0.001^{*} \\
(1.69)\end{array}$ & $\begin{array}{l}0.012 \\
(1.28)\end{array}$ & $\begin{array}{c}0.029^{* *} \\
(2.14)\end{array}$ & $\begin{array}{c}0.027^{* *} \\
(2.05)\end{array}$ \\
\hline Family funds (log) & $\begin{array}{l}0.000 \\
(0.68)\end{array}$ & $\begin{array}{l}-0.000 \\
(-0.35)\end{array}$ & $\begin{array}{l}0.001 \\
(1.27)\end{array}$ & $\begin{array}{l}0.006 \\
(0.51)\end{array}$ & $\begin{array}{l}-0.008 \\
(-0.49)\end{array}$ & $\begin{array}{l}0.014 \\
(1.22)\end{array}$ \\
\hline Family age (log) & $\begin{array}{c}0.004^{* * *} \\
(4.14)\end{array}$ & $\begin{array}{c}0.003^{* *} \\
(2.04)\end{array}$ & $\begin{array}{c}0.004^{* * *} \\
(4.74)\end{array}$ & $\begin{array}{c}0.069^{* * *} \\
(3.90)\end{array}$ & $\begin{array}{c}0.044^{*} \\
(1.84)\end{array}$ & $\begin{array}{c}0.079^{* * *} \\
(4.53)\end{array}$ \\
\hline Family cash & $\begin{array}{c}0.001^{* * *} \\
(5.49)\end{array}$ & $\begin{array}{c}0.001^{* * *} \\
(3.26)\end{array}$ & $\begin{array}{c}0.001^{* * *} \\
(4.86)\end{array}$ & $\begin{array}{c}0.026^{* * *} \\
(5.33)\end{array}$ & $\begin{array}{c}0.019^{* * *} \\
(3.14)\end{array}$ & $\begin{array}{c}0.024^{* * *} \\
(4.71)\end{array}$ \\
\hline Family turnover & $\begin{array}{l}-0.000 \\
(-0.13)\end{array}$ & $\begin{array}{l}-0.001 \\
(-0.85)\end{array}$ & $\begin{array}{l}0.000 \\
(0.05)\end{array}$ & $\begin{array}{l}-0.008 \\
(-0.41)\end{array}$ & $\begin{array}{l}-0.024 \\
(-1.12)\end{array}$ & $\begin{array}{l}-0.005 \\
(-0.23)\end{array}$ \\
\hline Family front load & $\begin{array}{c}-0.010^{* * *} \\
(-3.72)\end{array}$ & $\begin{array}{c}-0.010^{* * *} \\
(-3.59)\end{array}$ & $\begin{array}{c}-0.010^{* * *} \\
(-3.64)\end{array}$ & $\begin{array}{c}-0.202^{* * *} \\
(-3.94)\end{array}$ & $\begin{array}{c}-0.206^{* * *} \\
(-3.77)\end{array}$ & $\begin{array}{c}-0.216^{* * *} \\
(-3.82)\end{array}$ \\
\hline Family gross return & $\begin{array}{l}0.019 \\
(0.22)\end{array}$ & $\begin{array}{l}0.040 \\
(0.41)\end{array}$ & $\begin{array}{l}0.041 \\
(0.45)\end{array}$ & $\begin{array}{l}0.367 \\
(0.21)\end{array}$ & $\begin{array}{l}0.797 \\
(0.41)\end{array}$ & $\begin{array}{l}0.818 \\
(0.45)\end{array}$ \\
\hline No. of observations & 15,253 & 15,253 & 15,253 & 15,333 & 15,333 & 15,333 \\
\hline Adjusted $R^{2}$ & 0.046 & 0.037 & 0.044 & 0.042 & 0.033 & 0.040 \\
\hline
\end{tabular}


Table 8:

Active share and tracking error

The table lists the results of following regression specification: Activeness $s_{i, t}=\beta_{0}+$ $\beta_{1}$ Competitive/Cooperative $_{j, t}+$ controls $+\epsilon_{i, t}$, where Activeness $s_{i, t}$ measures the active share and tracking error of fund $i$ at time $t$. Active share and tracking error are obtained from Cremers as in Cremers and Petajisto (2009). Competitive/Cooperative ${ }_{j, t}$ is a standardized index that measures the fund family $j$ competitive and cooperative incentives at time $t$. We also include the Net competitive (competitive - cooperative) effect. Variable definitions are the Data Appendix. The constant term is included but not reported. The $t$-statistics are reported in parentheses; standard errors are clustered at the fund level. * denotes significance at the $10 \%$ level, ${ }^{* *}$ denotes significance at the $5 \%$ level, and $* * *$ denotes significance at the $1 \%$ level.

\begin{tabular}{|c|c|c|c|c|c|c|}
\hline \multirow[b]{2}{*}{ Competitive } & \multicolumn{3}{|c|}{ Active share } & \multicolumn{3}{|c|}{ Tracking error } \\
\hline & $\begin{array}{c}0.015^{* * *} \\
(7.01)\end{array}$ & & & $\begin{array}{c}0.004^{* * *} \\
(7.22)\end{array}$ & & \\
\hline Cooperative & & $\begin{array}{c}-0.009^{* * *} \\
(-3.65)\end{array}$ & & & $\begin{array}{c}-0.002^{* * *} \\
(-4.01)\end{array}$ & \\
\hline Net competitive & & & $\begin{array}{c}0.016^{* * *} \\
(6.33)\end{array}$ & & & $\begin{array}{c}0.004^{* * *} \\
(6.65)\end{array}$ \\
\hline Family size (log TNA) & $\begin{array}{c}-0.003^{*} \\
(-1.85)\end{array}$ & $\begin{array}{c}-0.004^{* *} \\
(-2.29)\end{array}$ & $\begin{array}{l}-0.002 \\
(-1.25)\end{array}$ & $\begin{array}{c}-0.002^{* * *} \\
(-5.81)\end{array}$ & $\begin{array}{c}-0.002^{* * *} \\
(-6.57)\end{array}$ & $\begin{array}{c}-0.002^{* * *} \\
(-5.32)\end{array}$ \\
\hline Family funds (log) & $\begin{array}{c}-0.017^{* * *} \\
(-7.34)\end{array}$ & $\begin{array}{c}-0.017^{* * *} \\
(-7.06)\end{array}$ & $\begin{array}{c}-0.017^{* * *} \\
(-7.18)\end{array}$ & $\begin{array}{c}-0.002^{* * *} \\
(-4.43)\end{array}$ & $\begin{array}{c}-0.002^{* * *} \\
(-4.15)\end{array}$ & $\begin{array}{c}-0.002^{* * *} \\
(-4.25)\end{array}$ \\
\hline Fund size (log TNA) & $\begin{array}{l}0.000 \\
(0.31)\end{array}$ & $\begin{array}{l}0.000 \\
(0.23)\end{array}$ & $\begin{array}{l}0.000 \\
(0.08)\end{array}$ & $\begin{array}{c}0.001^{* *} \\
(2.19)\end{array}$ & $\begin{array}{c}0.001^{* *} \\
(2.07)\end{array}$ & $\begin{array}{c}0.001^{*} \\
(1.92)\end{array}$ \\
\hline Expense ratio (\%) & $\begin{array}{c}0.083^{* * *} \\
(11.51)\end{array}$ & $\begin{array}{c}0.083^{* * *} \\
(11.30)\end{array}$ & $\begin{array}{c}0.083^{* * *} \\
(11.34)\end{array}$ & $\begin{array}{c}0.021^{* * *} \\
(11.45)\end{array}$ & $\begin{array}{c}0.020^{* * *} \\
(11.37)\end{array}$ & $\begin{array}{c}0.020^{* * *} \\
(11.37)\end{array}$ \\
\hline Fund turnover & $\begin{array}{l}-0.004 \\
(-1.15)\end{array}$ & $\begin{array}{l}-0.004 \\
(-1.19)\end{array}$ & $\begin{array}{l}-0.004 \\
(-1.16)\end{array}$ & $\begin{array}{c}0.006^{* * *} \\
(6.15)\end{array}$ & $\begin{array}{c}0.006^{* * *} \\
(6.07)\end{array}$ & $\begin{array}{c}0.006^{* * *} \\
(6.14)\end{array}$ \\
\hline Fund flows (monthly) & $\begin{array}{l}-0.000 \\
(-0.87)\end{array}$ & $\begin{array}{l}-0.000 \\
(-0.02)\end{array}$ & $\begin{array}{l}-0.000 \\
(-0.31)\end{array}$ & $\begin{array}{c}-0.000^{* * *} \\
(-9.46)\end{array}$ & $\begin{array}{c}-0.000^{* * *} \\
(-7.86)\end{array}$ & $\begin{array}{c}-0.000^{* * *} \\
(-8.61)\end{array}$ \\
\hline Fund age & $\begin{array}{c}0.004^{* *} \\
(2.03)\end{array}$ & $\begin{array}{c}0.004^{* *} \\
(2.02)\end{array}$ & $\begin{array}{c}0.004^{* *} \\
(1.98)\end{array}$ & $\begin{array}{c}0.002^{* * * *} \\
(3.09)\end{array}$ & $\begin{array}{c}0.002^{* * *} \\
(3.11)\end{array}$ & $\begin{array}{c}0.002^{* * *} \\
(3.07)\end{array}$ \\
\hline Style dummies & $\mathrm{Y}$ & $\mathrm{Y}$ & $\mathrm{Y}$ & $\mathrm{Y}$ & $\mathrm{Y}$ & $\mathrm{Y}$ \\
\hline Time dummies & $\mathrm{Y}$ & $\mathrm{Y}$ & $\mathrm{Y}$ & $\mathrm{Y}$ & $\mathrm{Y}$ & $\mathrm{Y}$ \\
\hline No. of observations & 342,683 & 342,683 & 342,683 & 342,683 & 342,683 & 342,683 \\
\hline Adjusted $R^{2}$ & 0.325 & 0.319 & 0.324 & 0.357 & 0.352 & 0.356 \\
\hline
\end{tabular}




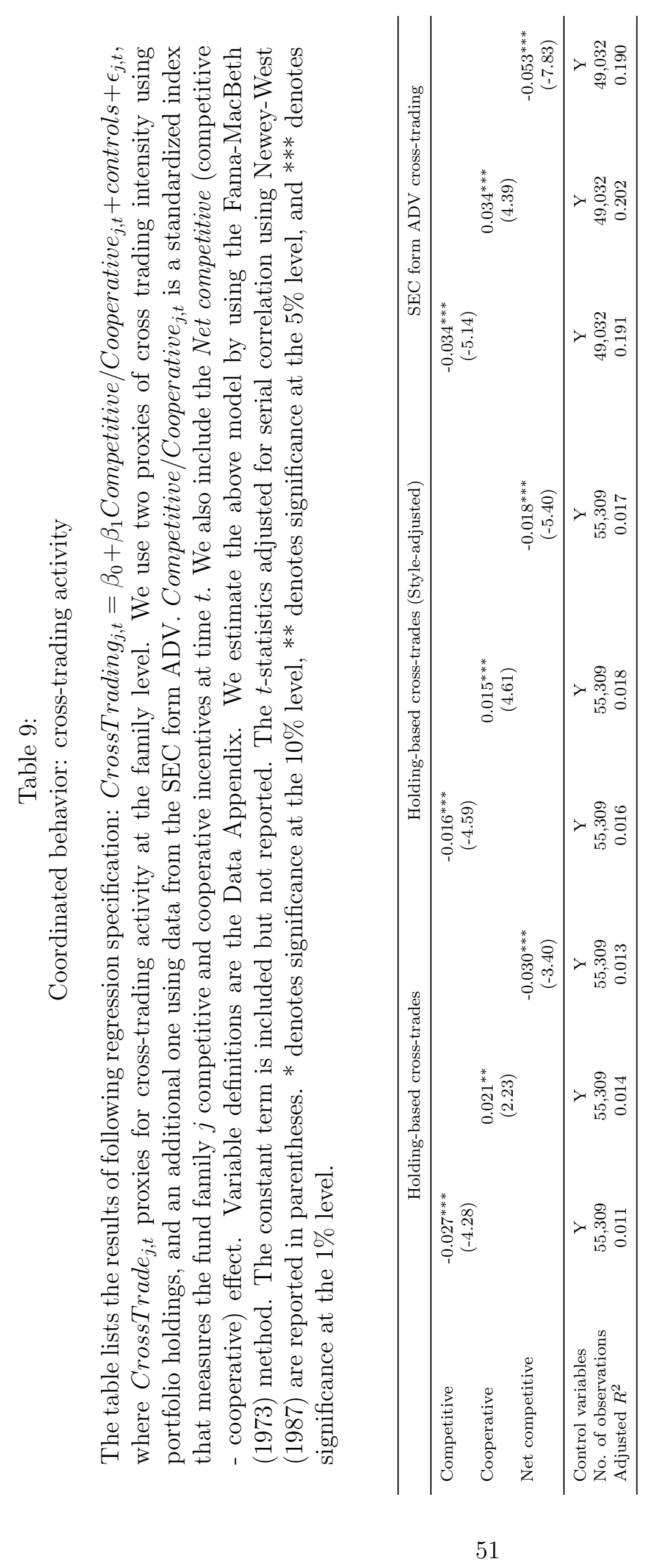


Table 10:

Coordinated behavior: cross-holding activity

The table presents the estimates of the likelihood associated with a fund being held by other funds within the family in times of distress. We define a distressed fund if it suffers an outflows larger than $5 \%$ during the quarter. Competitive/Cooperative ${ }_{j, t}$ is a standardized index that measures the fund family $j$ competitive and cooperative incentives at time $t$. We also include the Net competitive (competitive - cooperative) effect. Variable definitions are the Data Appendix. We estimate the specification using logistic regression with time and investment objective dummies interacted and robust standard errors adjusted for fund-level clustering. * denotes significance at the $10 \%$ level, $* *$ denotes significance at the $5 \%$ level, and $* * *$ denotes significance at the $1 \%$ level.

\begin{tabular}{|c|c|c|c|c|c|c|}
\hline \multirow[b]{2}{*}{ Distress } & \multicolumn{6}{|c|}{ Cross-holding funds } \\
\hline & $\begin{array}{c}1.259^{* * *} \\
(8.39)\end{array}$ & $\begin{array}{c}1.255^{* * *} \\
(8.21)\end{array}$ & $\begin{array}{c}1.248^{* * *} \\
(7.99)\end{array}$ & $\begin{array}{c}1.205^{* * *} \\
(6.79)\end{array}$ & $\begin{array}{c}1.201^{* * *} \\
(6.60)\end{array}$ & $\begin{array}{c}1.195^{* * *} \\
(6.39)\end{array}$ \\
\hline Competitive & $\begin{array}{r}1.049 \\
(1.55)\end{array}$ & & & $\begin{array}{l}1.054^{*} \\
(1.68)\end{array}$ & & \\
\hline Cooperative & & $\begin{array}{c}0.980 \\
(-0.69)\end{array}$ & & & $\begin{array}{c}0.989 \\
(-0.37)\end{array}$ & \\
\hline Net competitive & & & $\begin{array}{l}1.043 \\
(1.27)\end{array}$ & & & $\begin{array}{c}1.039 \\
(1.13)\end{array}$ \\
\hline Distress $\times$ Competitive & $\begin{array}{c}0.908^{* * *} \\
(-3.13)\end{array}$ & & & $\begin{array}{c}0.912^{* * *} \\
(-2.90)\end{array}$ & & \\
\hline Distress $\times$ Cooperative & & $\begin{array}{c}1.094^{* * *} \\
(3.12)\end{array}$ & & & $\begin{array}{c}1.087^{* * *} \\
(2.83)\end{array}$ & \\
\hline Distress $\times$ Net competitive & & & $\begin{array}{c}0.885^{* * *} \\
(-3.87)\end{array}$ & & & $\begin{array}{c}0.892^{* * * *} \\
(-3.51)\end{array}$ \\
\hline Style*Time dummies & $\mathrm{N}$ & $\mathrm{N}$ & $\mathrm{N}$ & $\mathrm{Y}$ & $\mathrm{Y}$ & $\mathrm{Y}$ \\
\hline Time dummies & $\mathrm{Y}$ & $\mathrm{Y}$ & $\mathrm{Y}$ & $\mathrm{N}$ & $\mathrm{N}$ & $\mathrm{N}$ \\
\hline Control Variables & $\mathrm{Y}$ & $\mathrm{Y}$ & $\mathrm{Y}$ & $\mathrm{Y}$ & $\mathrm{Y}$ & $\mathrm{Y}$ \\
\hline No. of observations & 491,670 & 491,670 & 491,670 & 491,112 & 491,112 & 491,112 \\
\hline
\end{tabular}


Table 11:

Fund family incentives: clientele and distribution channel

The table lists the results of following regression specification: Competitive/Cooperative $_{j, t}=\beta_{0}+\beta_{1}$ InstitutionalClientele $_{j, t}+$ controls $+\epsilon_{i, t}$, where Competitive/Cooperative ${ }_{j, t}$ is a standardized index that measures the fund family $j$ competitive and cooperative incentives at time $t$. InstitutionalClientele $e_{j, t}$ measures proportion of family $j$ assets under management from funds sold without a load fee (Direct distribution channel) and whether fund family has managers that not only run mutual funds but also other pooled investment vehicles (Side-by-side). Variable definitions are the Data Appendix. We estimate the above model by using the Fama-MacBeth (1973) method. The constant term is included but not reported. The $t$-statistics adjusted for serial correlation using Newey-West (1987) are reported in parentheses. * denotes significance at the $10 \%$ level, ** denotes significance at the $5 \%$ level, and ${ }^{* * *}$ denotes significance at the $1 \%$ level.

\begin{tabular}{|c|c|c|c|c|}
\hline \multirow[b]{2}{*}{ Direct distribution channel } & \multicolumn{4}{|c|}{ Net competitive index } \\
\hline & $\begin{array}{c}0.048^{* * *} \\
(3.66)\end{array}$ & & $\begin{array}{c}0.030^{* *} \\
(2.27)\end{array}$ & \\
\hline Side-by-side & & $\begin{array}{c}0.054^{* *} \\
(2.45)\end{array}$ & & $\begin{array}{c}0.066^{*} \\
(1.67)\end{array}$ \\
\hline Family size (log TNA) & $\begin{array}{c}-0.090^{* * *} \\
(-21.57)\end{array}$ & $\begin{array}{c}-0.113^{* * *} \\
(-8.84)\end{array}$ & $\begin{array}{c}-0.108^{* * *} \\
(-30.07)\end{array}$ & $\begin{array}{c}-0.197^{* * *} \\
(-5.12)\end{array}$ \\
\hline Family funds (log) & $\begin{array}{c}-0.192^{* * *} \\
(-28.48)\end{array}$ & $\begin{array}{l}-0.034 \\
(-1.00)\end{array}$ & $\begin{array}{c}-0.168^{* * *} \\
(-15.90)\end{array}$ & $\begin{array}{c}0.151^{* * *} \\
(3.01)\end{array}$ \\
\hline Family expense ratio & $\begin{array}{c}0.129^{* * *} \\
(7.92)\end{array}$ & $\begin{array}{c}-0.212^{* * *} \\
(-9.36)\end{array}$ & $\begin{array}{c}0.081^{* * *} \\
(5.10)\end{array}$ & $\begin{array}{c}-0.163^{* *} \\
(-2.12)\end{array}$ \\
\hline Family age (log) & & & $\begin{array}{c}0.081^{* * *} \\
(13.26)\end{array}$ & $\begin{array}{l}0.085 \\
(1.36)\end{array}$ \\
\hline Family stocks (log) & & & $\begin{array}{c}-0.016^{*} \\
(-1.94)\end{array}$ & $\begin{array}{c}-0.080^{*} \\
(-1.67)\end{array}$ \\
\hline Family cash & & & $\begin{array}{c}0.006^{* * *} \\
(10.45)\end{array}$ & $\begin{array}{c}0.033^{* * *} \\
(3.56)\end{array}$ \\
\hline Family turnover & & & $\begin{array}{l}-0.008 \\
(-1.38)\end{array}$ & $\begin{array}{c}-0.162^{* *} \\
(-2.05)\end{array}$ \\
\hline Family gross return & & & $\begin{array}{c}0.600^{* *} \\
(2.31)\end{array}$ & $\begin{array}{l}-0.162 \\
(-0.05)\end{array}$ \\
\hline No. of observations & 128,089 & 4,050 & 127,444 & 4,050 \\
\hline Adjusted $R^{2}$ & 0.212 & 0.079 & 0.219 & 0.063 \\
\hline
\end{tabular}


Table 12:

The effect of investment advisor M\&A on target funds

This table presents the effect of competition/cooperation incentives of the acquirer company on the funds of the target company, before and after the merger. The dependent variables are the Active share, Tracking error, Cross-trading, and Fund cross-holding. $\Delta$ Net competition measures the difference between the net competitive incentives of the acquirer family and target family during the year before their target funds were acquired. Post-event is a dummy variable that is equal to one during the 24 months after the merger and zero during the prior 24 months. We estimate these models using fund fixed-effects for funds of families that were acquired by other firms. The $t$-statistics are reported in parentheses; standard errors are clustered at the fund and year level. denotes significance at the $10 \%$ level, ${ }^{* *}$ denotes significance at the $5 \%$ level, and *** denotes significance at the $1 \%$ level.

\begin{tabular}{|c|c|c|c|c|}
\hline & \multicolumn{4}{|c|}{ Target funds } \\
\hline & Active share & Tracking error & Cross-trades & Fund cross-holding \\
\hline Post-event x $\Delta$ Net Competition & $\begin{array}{c}0.026^{* * *} \\
\quad(4.61)\end{array}$ & $\begin{array}{c}0.005^{* * *} \\
(2.83)\end{array}$ & $\begin{array}{c}-0.335^{*} \\
(-1.71)\end{array}$ & $\begin{array}{c}-0.524^{* * *} \\
(-4.12)\end{array}$ \\
\hline Post-event & $\begin{array}{c}0.016^{* *} \\
(2.06)\end{array}$ & $\begin{array}{c}0.010^{* * *} \\
(3.81)\end{array}$ & $\begin{array}{l}0.138 \\
(0.68)\end{array}$ & $\begin{array}{c}-0.612^{* *} \\
(-2.03)\end{array}$ \\
\hline Family size (log TNA) & $\begin{array}{c}-0.020^{* * *} \\
(-6.95)\end{array}$ & $\begin{array}{c}-0.003^{* * *} \\
(-3.40)\end{array}$ & $\begin{array}{l}-0.056 \\
(-0.97)\end{array}$ & $\begin{array}{l}-0.013 \\
(-0.39)\end{array}$ \\
\hline Family funds (log) & $\begin{array}{c}0.009^{* * *} \\
(3.23)\end{array}$ & $\begin{array}{l}-0.000 \\
(-0.25)\end{array}$ & $\begin{array}{l}0.064 \\
(1.23)\end{array}$ & $\begin{array}{l}-0.037 \\
(-0.78)\end{array}$ \\
\hline Fund size (log TNA) & $\begin{array}{c}-0.007^{* * *} \\
(-3.83)\end{array}$ & $\begin{array}{c}-0.002^{* * *} \\
(-2.96)\end{array}$ & $\begin{array}{l}-0.060 \\
(-1.12)\end{array}$ & $\begin{array}{c}0.076 \\
(1.11)\end{array}$ \\
\hline Expense ratio (\%) & $\begin{array}{c}0.013^{*} \\
(1.71)\end{array}$ & $\begin{array}{c}-0.004^{*} \\
(-1.80)\end{array}$ & $\begin{array}{c}0.277 \\
(1.54)\end{array}$ & $\begin{array}{c}0.664^{*} \\
(1.82)\end{array}$ \\
\hline Front load & $\begin{array}{c}-0.022^{* *} \\
(-2.17)\end{array}$ & $\begin{array}{l}-0.004 \\
(-0.87)\end{array}$ & $\begin{array}{c}1.338^{* * *} \\
(2.88)\end{array}$ & $\begin{array}{c}-0.332^{* *} \\
(-2.44)\end{array}$ \\
\hline Fund turnover & $\begin{array}{l}-0.004 \\
(-1.55)\end{array}$ & $\begin{array}{l}-0.001 \\
(-0.65)\end{array}$ & $\begin{array}{c}0.226^{* *} \\
(2.42)\end{array}$ & $\begin{array}{l}-0.002 \\
(-0.03)\end{array}$ \\
\hline Fund age (log) & $\begin{array}{c}0.000 \\
(0.05)\end{array}$ & $\begin{array}{c}-0.001^{* *} \\
(-1.98)\end{array}$ & $\begin{array}{l}-0.036 \\
(-0.58)\end{array}$ & $\begin{array}{c}0.081^{* *} \\
(2.15)\end{array}$ \\
\hline Past returns (yearly) & $\begin{array}{c}0.013^{* *} \\
(1.99)\end{array}$ & $\begin{array}{c}-0.006^{*} \\
(-1.83)\end{array}$ & $\begin{array}{l}0.289 \\
(1.57)\end{array}$ & $\begin{array}{c}0.087 \\
(0.73)\end{array}$ \\
\hline Past flows & $\begin{array}{l}-0.000 \\
(-0.32)\end{array}$ & $\begin{array}{l}0.000 \\
(1.45)\end{array}$ & $\begin{array}{c}0.001 \\
(0.10)\end{array}$ & $\begin{array}{l}-0.004 \\
(-0.88)\end{array}$ \\
\hline Manager tenure & $\begin{array}{l}-0.000 \\
(-0.64)\end{array}$ & $\begin{array}{c}0.000 \\
(0.71)\end{array}$ & $\begin{array}{c}0.007 \\
(0.52)\end{array}$ & $\begin{array}{c}0.003 \\
(0.23)\end{array}$ \\
\hline Fund FE & $\mathrm{Y}$ & $\mathrm{Y}$ & $\mathrm{Y}$ & $\mathrm{Y}$ \\
\hline Time dummies & $\mathrm{Y}$ & $\mathrm{Y}$ & $\mathrm{Y}$ & $\mathrm{Y}$ \\
\hline No. of observations & 22,435 & 22,435 & 44,624 & 64,853 \\
\hline Adjusted $R^{2}$ & 0.778 & 0.551 & 0.131 & 0.700 \\
\hline
\end{tabular}


Table 13:

Pseudo families: falsification test

This table shows the Fama-MacBeth (1973) estimation of the effect of net competitive incentives on pseudo fund family strategies. The dependent variables are the overall family performance, performance dispersion, cross-trading activity, and cross-holding at the family level. Variable definitions are the Data Appendix. We estimate this model for pseudo fund families that were constructed upon randomly assigned funds matching on family size, number of funds, and fund style. The constant term is included but not reported. The $t$-statistics adjusted for serial correlation using Newey-West (1987) are reported in parentheses. $*$ denotes significance at the $10 \%$ level, $* *$ denotes significance at the $5 \%$ level, and $* * *$ denotes significance at the $1 \%$ level.

\begin{tabular}{|c|c|c|c|c|}
\hline & \multicolumn{4}{|c|}{ Falsification test: pseudo families } \\
\hline & Family performance & Performance dispersion & Cross-trades & Cross-holding \\
\hline \multirow[t]{2}{*}{ Net competitive } & 0.012 & 0.470 & -0.009 & 0.095 \\
\hline & $(1.52)$ & $(1.30)$ & $(-1.34)$ & $(1.51)$ \\
\hline \multirow[t]{2}{*}{ Family size } & $0.033^{* * *}$ & 0.127 & $-0.021^{* * *}$ & $-0.252^{* * *}$ \\
\hline & $(6.06)$ & $(0.48)$ & $(-3.42)$ & $(-6.16)$ \\
\hline \multirow{2}{*}{ Family funds } & $-0.050^{* * *}$ & $49.983^{* * *}$ & $0.131^{* * *}$ & $3.249^{* * *}$ \\
\hline & $(-3.29)$ & $(17.91)$ & $(8.11)$ & $(7.78)$ \\
\hline \multirow[t]{2}{*}{ Family age (log) } & $-0.038^{* * *}$ & $2.249^{* * *}$ & $0.020^{* *}$ & $-0.465^{* * *}$ \\
\hline & $(-3.84)$ & $(5.35)$ & $(2.29)$ & $(-5.95)$ \\
\hline \multirow[t]{2}{*}{ Family cash } & -0.003 & $0.182^{* * *}$ & -0.001 & $0.013^{* * *}$ \\
\hline & $(-1.37)$ & $(3.06)$ & $(-1.38)$ & $(3.79)$ \\
\hline \multirow[t]{2}{*}{ Family expense ratio } & 0.009 & $30.271^{* * *}$ & -0.000 & $-0.791^{* * *}$ \\
\hline & $(0.26)$ & $(20.68)$ & $(-0.04)$ & $(-6.15)$ \\
\hline \multirow[t]{2}{*}{ Family turnover } & -0.001 & $5.993^{* * *}$ & $0.026^{* * *}$ & $0.290^{* * *}$ \\
\hline & $(-0.06)$ & $(6.18)$ & $(3.01)$ & $(5.11)$ \\
\hline \multirow[t]{2}{*}{ Family front load } & $-0.046^{* * *}$ & $-11.002^{* * *}$ & 0.019 & $-0.195^{* *}$ \\
\hline & $(-3.43)$ & $(-12.73)$ & $(1.13)$ & $(-2.33)$ \\
\hline No. of observations & 120,964 & 94,582 & 112,299 & 120,964 \\
\hline Adjusted $R^{2}$ & 0.056 & 0.223 & 0.014 & 0.047 \\
\hline
\end{tabular}




\title{
Internet Appendix for "Competition and cooperation in mutual fund families"
}

\author{
Richard B. Evans, Melissa Porras Prado, and Rafael Zambrana Galacho
}

This Internet Appendix reports the results of supplementary and robustness tests as described below:

Figure A1: Figure of Net competitive index over time

Table A1: Individual components: competitive

Table A2: Individual components: cooperative

Table A3: Individual components

Table A4: Robustness checks: family characteristics

Table A5: Alternative approaches: Equity, TNA-Weighted, and EW components

Table A6: Fund performance: net returns

Table A7: Fund performance: other measures

Table A8: Star funds: fund level

Table A9: Family star funds: dummy variables

Table A10: Performance dispersion: dummy variables

Table A11: Recapturing flows

Table A12: Coordinated behavior: other variables

Table A13: Robustness checks: financial conglomerates 


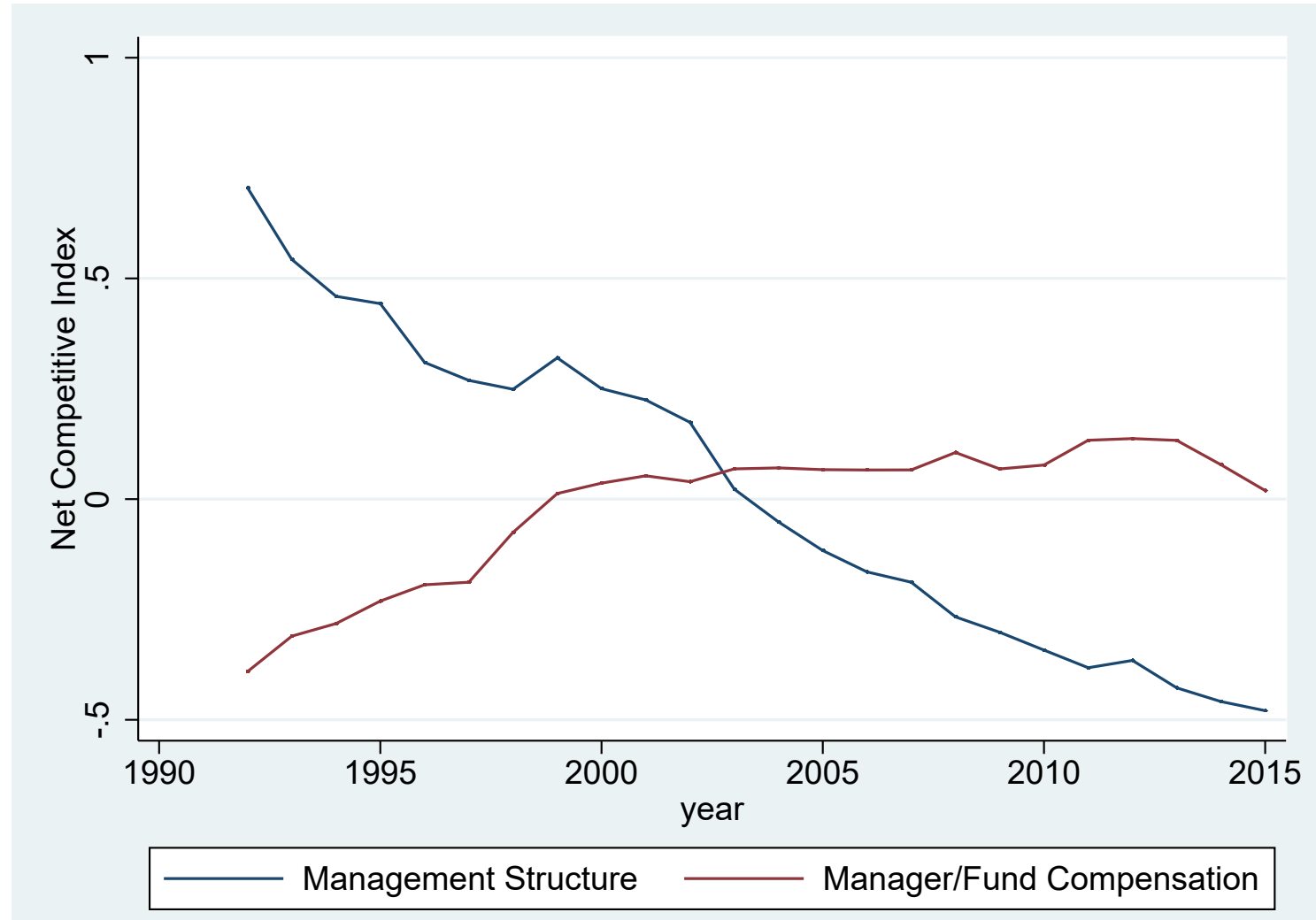

Figure 1: Net competitive index over time.

This plot shows the breakdown of our indices of fund manager incentives, competitive and cooperative, into two categories of the variables used: manager compensation incentives (e.g. manager ownership of the fund - competitive, manager ownership of the investment advisor - cooperative) and fund management structure (e.g. solo-managed fund - competitive or team-managed - cooperative). 
Table A1: Individual components: competitive

This table shows the Fama-MacBeth (1973) estimation of the effect of competitive and cooperative incentives on fund family strategies. The dependent variables are the percentage cross-trading and cross-holding activity of the fund and the star fund family strategies (proportion of star funds). Competitive and Cooperative are cross-sectional ranks. Variable definitions are the Data Appendix. The constant term and family control variables are included but not reported. The $t$-statistics adjusted for serial correlation using Newey-West (1987) are reported in parentheses. * denotes significance at the $10 \%$ level, ${ }^{* *}$ denotes significance at the $5 \%$ level, and $* * *$ denotes significance at the $1 \%$ level.

\begin{tabular}{|c|c|c|c|c|c|}
\hline & \multicolumn{5}{|c|}{ Competitive and cooperative incentives } \\
\hline & Family stars & Performance dispersion & Cross-trading & Active share & Tracking error \\
\hline CIR measure & $\begin{array}{c}0.041^{* * *} \\
(4.27)\end{array}$ & $\begin{array}{c}0.128^{* * *} \\
(3.66)\end{array}$ & $\begin{array}{c}0.329^{* * *} \\
(3.06)\end{array}$ & $\begin{array}{l}-0.011 \\
(-1.64)\end{array}$ & $\begin{array}{c}0.007^{* * *} \\
(3.23)\end{array}$ \\
\hline \multirow{4}{*}{$\begin{array}{l}\text { No. of observations } \\
\text { Adjusted } R^{2}\end{array}$} & 96,834 & 82,740 & 45,447 & 88,640 & 88,640 \\
\hline & 0.057 & 0.120 & 0.133 & 0.176 & 0.227 \\
\hline & \multicolumn{5}{|c|}{ Competitive and cooperative incentives } \\
\hline & Family stars & Performance dispersion & Cross-trading & Active share & Tracking error \\
\hline Individual fund & $\begin{array}{c}0.015^{* * *} \\
(3.34) \\
\end{array}$ & $\begin{array}{l}0.160^{* * *} \\
(6.36)\end{array}$ & $\begin{array}{c}-0.080^{* * *} \\
(-7.39)\end{array}$ & $\begin{array}{c}-0.025^{* * *} \\
(-3.54)\end{array}$ & $\begin{array}{c}0.007^{* * *} \\
(3.33)\end{array}$ \\
\hline \multirow{4}{*}{$\begin{array}{l}\text { No. of observations } \\
\text { Adjusted } R^{2}\end{array}$} & 105,299 & 86,209 & 49,009 & 93,492 & 93,492 \\
\hline & 0.053 & 0.120 & 0.090 & 0.185 & 0.238 \\
\hline & \multicolumn{5}{|c|}{ Competitive and cooperative incentives } \\
\hline & Family stars & Performance dispersion & Cross-trading & Active share & Tracking error \\
\hline Manager ownership & $\begin{array}{c}0.079^{* * *} \\
(12.74)\end{array}$ & $\begin{array}{l}0.132^{* * *} \\
\quad(8.05)\end{array}$ & $\begin{array}{l}0.072 \\
(1.27)\end{array}$ & $\begin{array}{c}0.126^{* * *} \\
(43.65)\end{array}$ & $\begin{array}{c}0.016^{* * *} \\
(14.14)\end{array}$ \\
\hline \multirow{4}{*}{$\begin{array}{l}\text { No. of observations } \\
\text { Adjusted } R^{2}\end{array}$} & 81,893 & 66,566 & 44,131 & 71,572 & 71,572 \\
\hline & 0.070 & 0.115 & 0.140 & 0.263 & 0.208 \\
\hline & & Competitive a & and cooperative in & centives & \\
\hline & Family stars & Performance dispersion & Cross-trading & Active share & Tracking error \\
\hline Bonus fund performance & $\begin{array}{c}-0.094^{* * *} \\
(-5.54)\end{array}$ & $\begin{array}{l}0.074^{*} \\
(1.86)\end{array}$ & $\begin{array}{l}0.066 \\
(1.35)\end{array}$ & $\begin{array}{l}-0.015 \\
(-1.49)\end{array}$ & $\begin{array}{c}0.011^{* *} \\
(2.56)\end{array}$ \\
\hline \multirow{4}{*}{$\begin{array}{l}\text { No. of observations } \\
\text { Adjusted } R^{2}\end{array}$} & 35,070 & 36,871 & 19,702 & 37,000 & 37,000 \\
\hline & 0.131 & 0.165 & 0.062 & 0.224 & 0.179 \\
\hline & & Competitive ar & nd cooperative inc & centives & \\
\hline & Family Stars & Performance dispersion & Cross-trading & Active share & Tracking error \\
\hline Bonus paid fund shares & $\begin{array}{c}-0.013^{* *} \\
(-2.19) \\
\end{array}$ & $\begin{array}{l}-0.028 \\
(-1.61) \\
\end{array}$ & $\begin{array}{c}-0.316^{* * *} \\
(-4.36) \\
\end{array}$ & $\begin{array}{c}0.010^{* * *} \\
(2.62) \\
\end{array}$ & $\begin{array}{c}0.004^{* * *} \\
(3.56) \\
\end{array}$ \\
\hline \multirow{4}{*}{$\begin{array}{l}\text { No. of observations } \\
\text { Adjusted } R^{2}\end{array}$} & 35,070 & 36,871 & 19,702 & 37,000 & 37,000 \\
\hline & 0.126 & 0.165 & 0.113 & 0.223 & 0.175 \\
\hline & & Competitive and & d cooperative ince & ntives & \\
\hline & Family stars & Performance dispersion & Cross-trading & Active share & Tracking error \\
\hline Bonus fund revenue & $\begin{array}{c}0.015^{* * *} \\
(2.65)\end{array}$ & $\begin{array}{c}0.038^{* *} \\
(2.28)\end{array}$ & $\begin{array}{l}0.047 \\
(1.54)\end{array}$ & $\begin{array}{c}0.041^{* * *} \\
(23.27)\end{array}$ & $\begin{array}{c}0.003^{* * *} \\
(3.97)\end{array}$ \\
\hline \multirow{2}{*}{$\begin{array}{l}\text { No. of observations } \\
\text { Adjusted } R^{2}\end{array}$} & 35,070 & 36,871 & 19,702 & 37,000 & 37,000 \\
\hline & 0.132 & 0.169 & 0.095 & 0.231 & 0.175 \\
\hline
\end{tabular}


Table A2: Individual components: cooperative

This table shows the Fama-MacBeth (1973) estimation of the effect of competitive and cooperative incentives on fund family strategies. The dependent variables are the percentage cross-trading and cross-holding activity of the fund and the star fund family strategies (proportion of star funds). Competitive and Cooperative are cross-sectional ranks. Variable definitions are the Data Appendix. The constant term and family control variables are included but not reported. The $t$-statistics adjusted for serial correlation using Newey-West (1987) are reported in parentheses. * denotes significance at the $10 \%$ level, ${ }^{* *}$ denotes significance at the $5 \%$ level, and $* * *$ denotes significance at the $1 \%$ level.

\begin{tabular}{|c|c|c|c|c|c|}
\hline & \multicolumn{5}{|c|}{ Competitive and cooperative incentives } \\
\hline & Family stars & Performance dispersion & Cross-trading & Active share & Tracking error \\
\hline Other funds fee & $\begin{array}{c}-0.031^{* * *} \\
(-10.98)\end{array}$ & $\begin{array}{l}0.003 \\
(0.22)\end{array}$ & $\begin{array}{l}0.028 \\
(0.90)\end{array}$ & $\begin{array}{c}-0.025^{* * *} \\
(-8.66)\end{array}$ & $\begin{array}{c}-0.002^{* *} \\
(-2.00)\end{array}$ \\
\hline \multirow{4}{*}{$\begin{array}{l}\text { No. of observations } \\
\text { Adjusted } R^{2}\end{array}$} & 102,100 & 85,452 & 48,279 & 91,829 & 91,829 \\
\hline & 0.053 & 0.118 & 0.108 & 0.184 & 0.229 \\
\hline & \multicolumn{5}{|c|}{ Competitive and cooperative incentives } \\
\hline & Family stars & Performance dispersion & Cross-trading & Active share & Tracking error \\
\hline Team fund & $\begin{array}{c}-0.038^{* * *} \\
(-7.08) \\
\end{array}$ & $\begin{array}{c}-0.119^{* * *} \\
(-4.00)\end{array}$ & $\begin{array}{c}0.171^{* * *} \\
(11.04)\end{array}$ & $\begin{array}{l}0.004 \\
(0.65) \\
\end{array}$ & $\begin{array}{c}-0.017^{* * *} \\
(-9.71)\end{array}$ \\
\hline \multirow{4}{*}{$\begin{array}{l}\text { No. of observations } \\
\text { Adjusted } R^{2}\end{array}$} & 105,299 & 86,209 & 49,009 & 93,492 & 93,492 \\
\hline & 0.054 & 0.119 & 0.101 & 0.185 & 0.242 \\
\hline & \multicolumn{5}{|c|}{ Competitive and cooperative incentives } \\
\hline & Family stars & Performance dispersion & Cross-trading & Active share & Tracking error \\
\hline Manager connected & $\begin{array}{c}-0.013^{* *} \\
(-2.51)\end{array}$ & $\begin{array}{c}-0.078^{* * *} \\
(-6.07)\end{array}$ & $\begin{array}{c}0.043^{* *} \\
(2.23)\end{array}$ & $\begin{array}{c}-0.014^{* * *} \\
(-3.58)\end{array}$ & $\begin{array}{c}-0.006^{* * *} \\
(-7.83)\end{array}$ \\
\hline \multirow{4}{*}{$\begin{array}{l}\text { No. of observations } \\
\text { Adjusted } R^{2}\end{array}$} & 97,945 & 82,901 & 47,963 & 88,173 & 88,173 \\
\hline & 0.059 & 0.117 & 0.123 & 0.196 & 0.198 \\
\hline & & Competitive an & d cooperative inc & entives & \\
\hline & Family stars & Performance dispersion & Cross-trading & Active share & Tracking rrror \\
\hline Managers/Fund ratio & $\begin{array}{c}-0.047^{* * *} \\
(-8.81)\end{array}$ & $\begin{array}{c}-0.104^{* * *} \\
(-6.87)\end{array}$ & $\begin{array}{c}0.136^{* * *} \\
(16.80)\end{array}$ & $\begin{array}{c}-0.018^{* * *} \\
(-7.09)\end{array}$ & $\begin{array}{c}-0.011^{* * *} \\
(-8.91)\end{array}$ \\
\hline \multirow{4}{*}{$\begin{array}{l}\text { No. of observations } \\
\text { Adjusted } R^{2}\end{array}$} & 97,806 & 82,763 & 48,635 & 87,802 & 87,802 \\
\hline & 0.064 & 0.118 & 0.099 & 0.196 & 0.206 \\
\hline & & Competitive ar & nd cooperative in & entives & \\
\hline & Family stars & Performance dispersion & Cross-trading & Active share & Tracking error \\
\hline Bonus paid adv equity & $\begin{array}{c}-0.019^{* *} \\
(-2.53) \\
\end{array}$ & $\begin{array}{c}0.150^{* * *} \\
(4.18) \\
\end{array}$ & $\begin{array}{c}0.302^{* * *} \\
(23.59) \\
\end{array}$ & $\begin{array}{c}0.056^{* * *} \\
(9.36) \\
\end{array}$ & $\begin{array}{c}0.010^{* * *} \\
(12.20) \\
\end{array}$ \\
\hline \multirow{4}{*}{$\begin{array}{l}\text { No. of observations } \\
\text { Adjusted } R^{2}\end{array}$} & 35,070 & 36,871 & 19,702 & 37,000 & 37,000 \\
\hline & 0.128 & 0.167 & 0.079 & 0.228 & 0.175 \\
\hline & & Competitive a & nd cooperative in & centives & \\
\hline & Family stars & Performance dispersion & Cross-trading & Active share & Tracking error \\
\hline Bonus adv contribution & $\begin{array}{c}-0.010^{* *} \\
(-2.59)\end{array}$ & $\begin{array}{c}-0.124^{* * *} \\
(-5.87)\end{array}$ & $\begin{array}{c}-0.066^{* * *} \\
(-2.72)\end{array}$ & $\begin{array}{l}0.002 \\
(0.55)\end{array}$ & $\begin{array}{c}0.009^{* * *} \\
(8.34)\end{array}$ \\
\hline \multirow{2}{*}{$\begin{array}{l}\text { No. of observations } \\
\text { Adjusted } R^{2}\end{array}$} & 35,070 & 36,871 & 19,702 & 37,000 & 37,000 \\
\hline & 0.126 & 0.168 & 0.075 & 0.224 & 0.183 \\
\hline
\end{tabular}


Table A3: Individual components

This table shows the Fama-MacBeth (1973) estimation of the effect of competitive and cooperative incentives on fund family strategies. The dependent variables are the percentage cross-trading and cross-holding activity of the fund and the star fund family strategies (proportion of star funds). Competitive and Cooperative are cross-sectional ranks. Variable definitions are the Data Appendix. The constant term and family control variables are included but not reported. The $t$-statistics adjusted for serial correlation using Newey-West (1987) are reported in parentheses. * denotes significance at the $10 \%$ level, $* *$ denotes significance at the $5 \%$ level, and $* * *$ denotes significance at the $1 \%$ level.

\begin{tabular}{|c|c|c|c|c|c|}
\hline \multicolumn{6}{|l|}{ Panel A: competitive incentives } \\
\hline CIR measure & $\begin{array}{c}0.031^{* *} \\
(2.53)\end{array}$ & $\begin{array}{l}0.419^{* * *} \\
\quad(6.91)\end{array}$ & $\begin{array}{c}0.235^{* * *} \\
(15.07)\end{array}$ & $\begin{array}{l}0.018 \\
(1.16)\end{array}$ & $\begin{array}{c}0.017^{* * *} \\
(7.15)\end{array}$ \\
\hline Individual fund & $\begin{array}{c}0.009 \\
(0.66)\end{array}$ & $\begin{array}{l}0.062 \\
(1.34)\end{array}$ & $\begin{array}{c}-0.065^{* * *} \\
(-2.89)\end{array}$ & $\begin{array}{c}0.023^{* * *} \\
(2.79)\end{array}$ & $\begin{array}{c}0.011^{* * *} \\
(5.62)\end{array}$ \\
\hline Manager ownership & $\begin{array}{c}0.094^{* * *} \\
(12.33)\end{array}$ & $\begin{array}{c}0.163^{* * *} \\
(10.12)\end{array}$ & $\begin{array}{c}-0.058^{* * *} \\
(-4.81)\end{array}$ & $\begin{array}{c}0.135^{* * *} \\
(34.96)\end{array}$ & $\begin{array}{c}0.022^{* * *} \\
(12.59)\end{array}$ \\
\hline Bonus-fund performance & $\begin{array}{c}-0.094^{* * *} \\
(-3.84)\end{array}$ & $\begin{array}{c}0.163^{* * *} \\
(2.94)\end{array}$ & $\begin{array}{c}0.186^{* * *} \\
(4.68)\end{array}$ & $\begin{array}{c}-0.023^{* *} \\
(-2.04)\end{array}$ & $\begin{array}{c}0.015^{* * *} \\
(3.70)\end{array}$ \\
\hline Bonus-paid in fund shares & $\begin{array}{l}-0.005 \\
(-0.79)\end{array}$ & $\begin{array}{l}0.001 \\
(0.06)\end{array}$ & $\begin{array}{c}-0.143^{* * *} \\
(-8.14)\end{array}$ & $\begin{array}{c}0.007^{* * *} \\
(3.03)\end{array}$ & $\begin{array}{c}0.006^{* * *} \\
(5.77)\end{array}$ \\
\hline Bonus-fund revenue & $\begin{array}{l}0.007^{*} \\
(1.82)\end{array}$ & $\begin{array}{l}-0.000 \\
(-0.01)\end{array}$ & $\begin{array}{l}0.050^{*} \\
(1.93)\end{array}$ & $\begin{array}{c}0.032^{* * *} \\
(10.81)\end{array}$ & $\begin{array}{l}-0.000 \\
(-0.60)\end{array}$ \\
\hline $\begin{array}{l}\text { Control variables } \\
\text { Adjusted } R^{2}\end{array}$ & $\begin{array}{c}\mathrm{Y} \\
0.177\end{array}$ & $\begin{array}{c}\mathrm{Y} \\
0.174\end{array}$ & $\begin{array}{c}\mathrm{Y} \\
0.155\end{array}$ & $\begin{array}{c}\mathrm{Y} \\
0.294\end{array}$ & $\begin{array}{c}\mathrm{Y} \\
0.234\end{array}$ \\
\hline \multicolumn{6}{|c|}{ Panel B: cooperative incentives } \\
\hline Other funds fee & $\begin{array}{c}-0.006^{* *} \\
(-2.33)\end{array}$ & $\begin{array}{l}-0.012 \\
(-1.09)\end{array}$ & $\begin{array}{l}-0.006 \\
(-0.16)\end{array}$ & $\begin{array}{c}-0.016^{* * *} \\
(-3.59)\end{array}$ & $\begin{array}{l}-0.001 \\
(-1.11)\end{array}$ \\
\hline Team fund & $\begin{array}{l}0.007 \\
(0.43)\end{array}$ & $\begin{array}{c}-0.106^{* * *} \\
(-2.60)\end{array}$ & $\begin{array}{l}0.026 \\
(0.53)\end{array}$ & $\begin{array}{l}-0.014 \\
(-1.02)\end{array}$ & $\begin{array}{c}-0.015^{* * *} \\
(-9.20)\end{array}$ \\
\hline Manager connected & $\begin{array}{c}-0.012^{* *} \\
(-2.51)\end{array}$ & $\begin{array}{c}-0.087^{* * *} \\
(-5.34)\end{array}$ & $\begin{array}{c}0.072^{* * *} \\
(3.92)\end{array}$ & $\begin{array}{c}-0.009^{* *} \\
(-2.40)\end{array}$ & $\begin{array}{c}-0.008^{* * *} \\
(-4.84)\end{array}$ \\
\hline Managers/Funds ratio & $\begin{array}{c}-0.064^{* * *} \\
(-7.14)\end{array}$ & $\begin{array}{c}-0.066^{* * *} \\
(-3.46)\end{array}$ & $\begin{array}{c}0.102^{* * *} \\
(5.39)\end{array}$ & $\begin{array}{c}-0.046^{* * *} \\
(-8.04)\end{array}$ & $\begin{array}{c}-0.005^{* * *} \\
(-6.09)\end{array}$ \\
\hline Bonus-paid in advisor equity & $\begin{array}{c}-0.017^{* *} \\
(-2.16)\end{array}$ & $\begin{array}{c}0.162^{* * *} \\
(4.39)\end{array}$ & $\begin{array}{c}0.354^{* * *} \\
(9.40)\end{array}$ & $\begin{array}{c}0.057^{* * *} \\
(10.73)\end{array}$ & $\begin{array}{c}0.009^{* * *} \\
(10.65)\end{array}$ \\
\hline Bonus-overall advisor revenue & $\begin{array}{c}-0.015^{* * *} \\
(-4.08)\end{array}$ & $\begin{array}{c}-0.134^{* * *} \\
(-6.09)\end{array}$ & $\begin{array}{c}-0.050^{*} \\
(-1.76)\end{array}$ & $\begin{array}{l}-0.002 \\
(-0.53)\end{array}$ & $\begin{array}{c}0.008^{* * *} \\
(8.82)\end{array}$ \\
\hline Control variables & $\mathrm{Y}$ & $\mathrm{Y}$ & $\mathrm{Y}$ & $\mathrm{Y}$ & $\mathrm{Y}$ \\
\hline Adjusted $R^{2}$ & 0.150 & 0.173 & 0.192 & 0.232 & 0.196 \\
\hline
\end{tabular}


Table A4: Robustness checks: family characteristics

Variable definitions are the Data Appendix. We estimate these models by using the Fama-MacBeth (1973) method. The constant term is included but not reported. The $t$-statistics adjusted for serial correlation using Newey-West (1987) are reported in parentheses. * denotes significance at the $10 \%$ level, ** denotes significance at the $5 \%$ level, and $* * *$ denotes significance at the $1 \%$ level.

\begin{tabular}{|c|c|c|c|c|c|}
\hline \multicolumn{6}{|c|}{ Panel A: style concentrated $(\mathrm{HHI}>0.95)$ families } \\
\hline & Family stars & Performance dispersion & Cross-trading & Active share & Tracking error \\
\hline Net competitive & $\begin{array}{c}0.019^{* * *} \\
(10.50)\end{array}$ & $\begin{array}{c}0.068^{* * *} \\
(3.37)\end{array}$ & $\begin{array}{c}-0.037^{* * *} \\
(-10.66)\end{array}$ & $\begin{array}{c}0.007^{* * *} \\
(3.46)\end{array}$ & $\begin{array}{c}0.003^{* * *} \\
(6.32)\end{array}$ \\
\hline Control variables & $\mathrm{Y}$ & $\mathrm{Y}$ & $\mathrm{Y}$ & $\mathrm{Y}$ & $\mathrm{Y}$ \\
\hline Adjusted $R^{2}$ & 0.063 & 0.072 & 0.085 & 0.120 & 0.201 \\
\hline \multicolumn{6}{|c|}{ Panel B: large families (top 4th quartile) } \\
\hline & Family stars & Performance dispersion & Cross-trading & Active share & Tracking error \\
\hline Net competitive & $\begin{array}{c}0.031^{* * *} \\
(8.23)\end{array}$ & $\begin{array}{c}0.086^{* * *} \\
(12.49) \\
\end{array}$ & $\begin{array}{c}-0.103^{* * *} \\
(-3.20) \\
\end{array}$ & $\begin{array}{c}0.021^{* * *} \\
(11.54) \\
\end{array}$ & $\begin{array}{c}0.003^{* * *} \\
(5.92)\end{array}$ \\
\hline Control variables & $\mathrm{Y}$ & $\mathrm{Y}$ & $\mathrm{Y}$ & $\mathrm{Y}$ & $\mathrm{Y}$ \\
\hline Adjusted $R^{2}$ & 0.140 & 0.150 & 0.067 & 0.283 & 0.198 \\
\hline \multicolumn{6}{|c|}{ Panel C: families with shrinking assets } \\
\hline & Family stars & Performance dispersion & Cross-trading & Active share & Tracking error \\
\hline Net competitive & $\begin{array}{c}0.008^{* * *} \\
(4.51)\end{array}$ & $\begin{array}{c}0.044^{* * *} \\
(4.31)\end{array}$ & $\begin{array}{c}-0.042^{* * *} \\
(-6.06) \\
\end{array}$ & $\begin{array}{c}0.012^{* * *} \\
(5.16)\end{array}$ & $\begin{array}{c}0.004^{* * *} \\
(6.39)\end{array}$ \\
\hline Control variables & Y & $\mathrm{Y}$ & $\mathrm{Y}$ & $\mathrm{Y}$ & $\mathrm{Y}$ \\
\hline Adjusted $R^{2}$ & 0.052 & 0.157 & 0.172 & 0.180 & 0.286 \\
\hline \multicolumn{6}{|c|}{ Panel D: families with growing assets } \\
\hline Net competitive & $\begin{array}{c}0.025^{* * *} \\
(11.41)\end{array}$ & $\begin{array}{c}0.041^{* * *} \\
(5.53)\end{array}$ & $\begin{array}{c}-0.079^{* * *} \\
(-3.49) \\
\end{array}$ & $\begin{array}{c}0.012^{* * *} \\
(5.56)\end{array}$ & $\begin{array}{c}0.005^{* * *} \\
(10.80)\end{array}$ \\
\hline Control variables & $\mathrm{Y}$ & $\mathrm{Y}$ & $\mathrm{Y}$ & $\mathrm{Y}$ & $\mathrm{Y}$ \\
\hline Adjusted $R^{2}$ & 0.082 & 0.123 & 0.134 & 0.214 & 0.241 \\
\hline
\end{tabular}


Continued from previous page

\begin{tabular}{|c|c|c|c|c|c|}
\hline Panel E: families & $\begin{array}{l}\text { below mediai } \\
\text { Family stars }\end{array}$ & Performance dispersion & Cross-trading & Active share & Tracking error \\
\hline Net competitive & $\begin{array}{l}0.014^{* * *} \\
\quad(6.80)\end{array}$ & $\begin{array}{l}0.037^{* * * *} \\
(5.48)\end{array}$ & $\begin{array}{c}-0.125^{* * *} \\
(-3.15)\end{array}$ & $\begin{array}{c}0.008^{* * *} \\
(3.45)\end{array}$ & $\begin{array}{l}0.003^{* * *} \\
(5.90)\end{array}$ \\
\hline $\begin{array}{l}\text { Control variables } \\
\text { Adjusted } R^{2}\end{array}$ & $\begin{array}{c}\mathrm{Y} \\
0.055\end{array}$ & $\begin{array}{c}\mathrm{Y} \\
0.085\end{array}$ & $\begin{array}{c}\mathrm{Y} \\
0.123\end{array}$ & $\begin{array}{c}\mathrm{Y} \\
0.210\end{array}$ & $\begin{array}{c}\mathrm{Y} \\
0.144\end{array}$ \\
\hline Panel F: families & $\begin{array}{l}\text { above mediar } \\
\text { Family stars }\end{array}$ & Performance dispersion & Cross-trading & Active share & Tracking error \\
\hline Net competitive & $\begin{array}{c}0.022^{* * *} \\
(10.33)\end{array}$ & $\begin{array}{l}0.059^{* * *} \\
(6.04)\end{array}$ & $\begin{array}{l}0.100 \\
(0.70)\end{array}$ & $\begin{array}{l}0.013^{* * *} \\
\quad(8.53)\end{array}$ & $\begin{array}{c}0.006^{* * *} \\
(13.46)\end{array}$ \\
\hline $\begin{array}{l}\text { Control variables } \\
\text { Adjusted } R^{2}\end{array}$ & $\begin{array}{c}\mathrm{Y} \\
0.057\end{array}$ & $\begin{array}{c}\mathrm{Y} \\
0.077\end{array}$ & $\begin{array}{c}\mathrm{Y} \\
0.127\end{array}$ & $\begin{array}{c}\mathrm{Y} \\
0.170\end{array}$ & $\begin{array}{c}\mathrm{Y} \\
0.219\end{array}$ \\
\hline Panel G: sample & $\begin{array}{l}\text { d: } 2005-2015 \\
\text { Family stars }\end{array}$ & Performance dispersion & Cross-trading & Active share & Tracking error \\
\hline Net competitive & $\begin{array}{c}0.021^{* * *} \\
(9.48)\end{array}$ & $\begin{array}{l}0.069^{* * *} \\
(8.76)\end{array}$ & $\begin{array}{c}-0.035^{* * *} \\
(-10.50)\end{array}$ & $\begin{array}{c}0.025^{* * *} \\
(18.47)\end{array}$ & $\begin{array}{c}0.007^{* * *} \\
(14.87)\end{array}$ \\
\hline $\begin{array}{l}\text { Control variables } \\
\text { Adjusted } R^{2}\end{array}$ & $\begin{array}{c}\mathrm{Y} \\
0.056\end{array}$ & $\begin{array}{c}\mathrm{Y} \\
0.114\end{array}$ & $\begin{array}{c}\mathrm{Y} \\
0.143 \\
\end{array}$ & $\begin{array}{c}\mathrm{Y} \\
0.249\end{array}$ & $\begin{array}{c}\mathrm{Y} \\
0.237\end{array}$ \\
\hline Panel H: sample p & $\begin{array}{l}\text { d: } 2005-2015 \\
\text { Family stars }\end{array}$ & $\begin{array}{l}\text { cluding financial crisis } \\
\text { Performance dispersion }\end{array}$ & $\begin{array}{l}\text { 7-2010)) } \\
\text { Cross-trading }\end{array}$ & Active share & Tracking error \\
\hline Net competitive & $\begin{array}{l}0.018^{* * *} \\
\quad(5.39)\end{array}$ & $\begin{array}{l}0.050^{* * *} \\
(6.52)\end{array}$ & $\begin{array}{c}-0.036^{* * *} \\
(-7.01)\end{array}$ & $\begin{array}{c}0.025^{* * *} \\
(12.62)\end{array}$ & $\begin{array}{c}0.007^{* * *} \\
(13.31)\end{array}$ \\
\hline $\begin{array}{l}\text { Control variables } \\
\text { Adjusted } R^{2}\end{array}$ & $\begin{array}{c}\mathrm{Y} \\
0.031\end{array}$ & $\begin{array}{c}\mathrm{Y} \\
0.117\end{array}$ & $\begin{array}{c}\mathrm{Y} \\
0.129\end{array}$ & $\begin{array}{c}\mathrm{Y} \\
0.236\end{array}$ & $\begin{array}{c}\mathrm{Y} \\
0.240\end{array}$ \\
\hline
\end{tabular}


Table A5: Alternative approaches: Equity, TNA-Weighted, and EW components

This table shows the Fama-MacBeth (1973) estimation of the effect of competitive and cooperative incentives on fund family strategies considering different ways of estimating family incentive scheme indices. In Panel A we consider only the equity information of fund families. Panel B shows the results of creating the indices using a TNA-weighted average of the fund characteristics. In Panel $\mathrm{C}$, we aggregate the components of the indices into two categories (human capital, and fund/manager compensation incentives) and give the same weight to each category. The dependent variables are the percentage cross-trading and cross-holding activity of the fund and the star fund family strategies (proportion of star funds). Competitive/Cooperative is a standardized index that measures fund family $j$ competitive, cooperative and Net competitive (competitive cooperative) incentives. Variable definitions are the Data Appendix. The constant term and family control variables are included but not reported. The $t$-statistics adjusted for serial correlation using Newey-West (1987) are reported in parentheses. * denotes significance at the $10 \%$ level, $* *$ denotes significance at the $5 \%$ level, and $* * *$ denotes significance at the $1 \%$ level.

\begin{tabular}{|c|c|c|c|c|c|}
\hline \multicolumn{6}{|c|}{ Panel A: Only domestic equity } \\
\hline Net competitive & $\begin{array}{c}0.020^{* * *} \\
(13.98)\end{array}$ & $\begin{array}{c}0.046^{* * *} \\
(7.66)\end{array}$ & $\begin{array}{c}-0.052^{* * *} \\
(-7.42)\end{array}$ & $\begin{array}{c}0.010^{* * *} \\
(5.08)\end{array}$ & $\begin{array}{c}0.004^{* * *} \\
(10.01)\end{array}$ \\
\hline No. of observations & 98,159 & 83,799 & 46,362 & 93,037 & 93,037 \\
\hline Adjusted $R^{2}$ & 0.068 & 0.125 & 0.097 & 0.196 & 0.239 \\
\hline \multicolumn{6}{|c|}{ Panel B: TNA-weighted } \\
\hline & Family stars & Performance dispersion & Cross-trading & Active share & Tracking error \\
\hline Net competitive & $\begin{array}{c}0.020^{* * *} \\
(13.16)\end{array}$ & $\begin{array}{c}0.051^{* * *} \\
\quad(8.68)\end{array}$ & $\begin{array}{c}-0.060^{* * *} \\
(-5.92)\end{array}$ & $\begin{array}{c}0.012^{* * *} \\
\quad(6.34)\end{array}$ & $\begin{array}{c}0.004^{* * *} \\
(11.17)\end{array}$ \\
\hline No. of observations & 105,299 & 86,209 & 49,009 & 93,492 & 93,492 \\
\hline Adjusted $R^{2}$ & 0.059 & 0.120 & 0.111 & 0.191 & 0.242 \\
\hline \multicolumn{6}{|c|}{ Panel C: Equally-weighted components } \\
\hline Net competitive & $\begin{array}{c}0.018^{* * *} \\
(13.26)\end{array}$ & $\begin{array}{c}0.041^{* * *} \\
(7.09)\end{array}$ & $\begin{array}{c}-0.055^{* * *} \\
(-4.47)\end{array}$ & $\begin{array}{c}0.010^{* * *} \\
(6.02)\end{array}$ & $\begin{array}{c}0.004^{* * *} \\
(10.23)\end{array}$ \\
\hline No. of observations & 105,299 & 86,209 & 49,009 & 93,492 & 93,492 \\
\hline Adjusted $R^{2}$ & 0.059 & 0.120 & 0.115 & 0.190 & 0.241 \\
\hline
\end{tabular}


Continued from previous page

Panel D: Components ranked by investment objective

Family stars Performance dispersion

Cross-trading Active share Tracking error

\begin{tabular}{|c|c|c|c|c|c|}
\hline Net competitive & $\begin{array}{c}0.017^{* * *} \\
(11.22)\end{array}$ & $\begin{array}{c}0.049^{* * *} \\
(9.21)\end{array}$ & $\begin{array}{c}-0.050^{* * *} \\
(-7.29)\end{array}$ & $\begin{array}{c}0.013^{* * *} \\
(7.19)\end{array}$ & $\begin{array}{c}0.004^{* * *} \\
\quad(9.66)\end{array}$ \\
\hline No. of observations & 105,299 & 86,209 & 49,009 & 93,492 & 93,492 \\
\hline Adjusted $R^{2}$ & 0.058 & 0.120 & 0.100 & 0.192 & 0.241 \\
\hline \multicolumn{6}{|c|}{ Panel E: PCA for cooperative incentives } \\
\hline & Family stars & Performance dispersion & Cross-trading & Active share & Tracking error \\
\hline PCA cooperative & $\begin{array}{c}-0.006^{* *} \\
(-2.35) \\
\end{array}$ & $\begin{array}{c}-0.055^{* * *} \\
(-9.81) \\
\end{array}$ & $\begin{array}{c}0.060^{* *} \\
(2.48) \\
\end{array}$ & $\begin{array}{c}-0.003^{*} \\
(-1.83) \\
\end{array}$ & $\begin{array}{c}-0.001^{* * *} \\
(-4.52) \\
\end{array}$ \\
\hline No. of Observations & 34,655 & 36,529 & 19,601 & 36,603 & 36,603 \\
\hline Adjusted $R^{2}$ & 0.136 & 0.171 & 0.180 & 0.229 & 0.176 \\
\hline \multicolumn{6}{|c|}{ Panel F: PCA for competitive incentives } \\
\hline & Family stars & Performance dispersion & Cross-trading & Active share & Tracking error \\
\hline PCA competitive & $\begin{array}{c}0.016^{* * * *} \\
(6.38)\end{array}$ & $\begin{array}{c}0.018^{* * *} \\
(2.72)\end{array}$ & $\begin{array}{l}0.086 \\
(0.72)\end{array}$ & $\begin{array}{c}0.023^{* * *} \\
(12.98)\end{array}$ & $\begin{array}{c}0.004^{* * *} \\
(9.86)\end{array}$ \\
\hline No. of observations & 28,512 & 29,577 & 17,091 & 29,791 & 29,791 \\
\hline Adjusted $R^{2}$ & 0.147 & 0.163 & 0.174 & 0.250 & 0.219 \\
\hline
\end{tabular}


Table A6: Fund performance: net returns

The table lists the results of following regression specification: FundPer formance ${ }_{i, t}=$ $\beta_{0}+\beta_{1}$ Competitive/Cooperative $_{j, t}+$ controls $+\epsilon_{i, t}$, where FundPer formance ${ }_{i, t}$ measures the performance of fund $i$ at time $t$ using the objective-adjusted returns after fees. Competitive/Cooperative $_{j, t}$ is a standardized index that measures the fund family $j$ competitive and cooperative incentives at time $t$. We also include the Net competitive (competitive - cooperative) effect. Variable definitions are the Data Appendix. We estimate the above model by using the Fama-MacBeth (1973) method. The constant term is included but not reported. The $t$-statistics adjusted for serial correlation using Newey-West (1987) are reported in parentheses. * denotes significance at the $10 \%$ level, ** denotes significance at the $5 \%$ level, and *** denotes significance at the $1 \%$ level.

\begin{tabular}{|c|c|c|c|c|c|c|}
\hline \multirow[b]{2}{*}{ Competitive } & \multicolumn{6}{|c|}{ Net performance } \\
\hline & $\begin{array}{c}0.018^{* * *} \\
(4.11)\end{array}$ & $\begin{array}{c}0.016^{* * *} \\
(3.85)\end{array}$ & & & & \\
\hline Cooperative & & & $\begin{array}{c}-0.010^{* *} \\
(-2.39)\end{array}$ & $\begin{array}{c}-0.010^{* *} \\
(-2.43)\end{array}$ & & \\
\hline Net competitive & & & & & $\begin{array}{c}0.018^{* * *} \\
(3.53)\end{array}$ & $\begin{array}{c}0.017^{* * *} \\
(3.43)\end{array}$ \\
\hline Family size (log TNA) & $\begin{array}{c}0.012^{* * *} \\
(5.63)\end{array}$ & $\begin{array}{c}0.010^{* * *} \\
(3.03)\end{array}$ & $\begin{array}{c}0.011^{* * *} \\
(5.26)\end{array}$ & $\begin{array}{c}0.009^{* * *} \\
(2.83)\end{array}$ & $\begin{array}{c}0.012^{* * *} \\
(6.18)\end{array}$ & $\begin{array}{c}0.011^{* * *} \\
(3.37)\end{array}$ \\
\hline Family funds (log) & $\begin{array}{l}0.004 \\
(0.58)\end{array}$ & $\begin{array}{l}0.003 \\
(0.49)\end{array}$ & $\begin{array}{l}0.005 \\
(0.73)\end{array}$ & $\begin{array}{l}0.004 \\
(0.65)\end{array}$ & $\begin{array}{l}0.005 \\
(0.68)\end{array}$ & $\begin{array}{l}0.004 \\
(0.59)\end{array}$ \\
\hline Fund size (log TNA) & & $\begin{array}{l}0.005 \\
(1.10)\end{array}$ & & $\begin{array}{l}0.005 \\
(1.02)\end{array}$ & & $\begin{array}{l}0.005 \\
(1.05)\end{array}$ \\
\hline Fund turnover & & $\begin{array}{l}0.009 \\
(0.60)\end{array}$ & & $\begin{array}{l}0.010 \\
(0.61)\end{array}$ & & $\begin{array}{l}0.010 \\
(0.61)\end{array}$ \\
\hline Fund flows (monthly) & & $\begin{array}{c}0.343^{* * *} \\
(6.83)\end{array}$ & & $\begin{array}{c}0.342^{* * *} \\
(6.85)\end{array}$ & & $\begin{array}{c}0.343^{* * *} \\
(6.84)\end{array}$ \\
\hline Fund age & & $\begin{array}{c}-0.010^{*} \\
(-1.72)\end{array}$ & & $\begin{array}{c}-0.009^{*} \\
(-1.66)\end{array}$ & & $\begin{array}{c}-0.010^{*} \\
(-1.73)\end{array}$ \\
\hline Style dummies & $\mathrm{Y}$ & $\mathrm{Y}$ & $\mathrm{Y}$ & $\mathrm{Y}$ & $\mathrm{Y}$ & $\mathrm{Y}$ \\
\hline No. of observations & $1,015,964$ & $1,006,554$ & $1,015,964$ & $1,006,554$ & $1,015,964$ & $1,006,554$ \\
\hline Adjusted $R^{2}$ & 0.005 & 0.019 & 0.005 & 0.019 & 0.006 & 0.019 \\
\hline
\end{tabular}




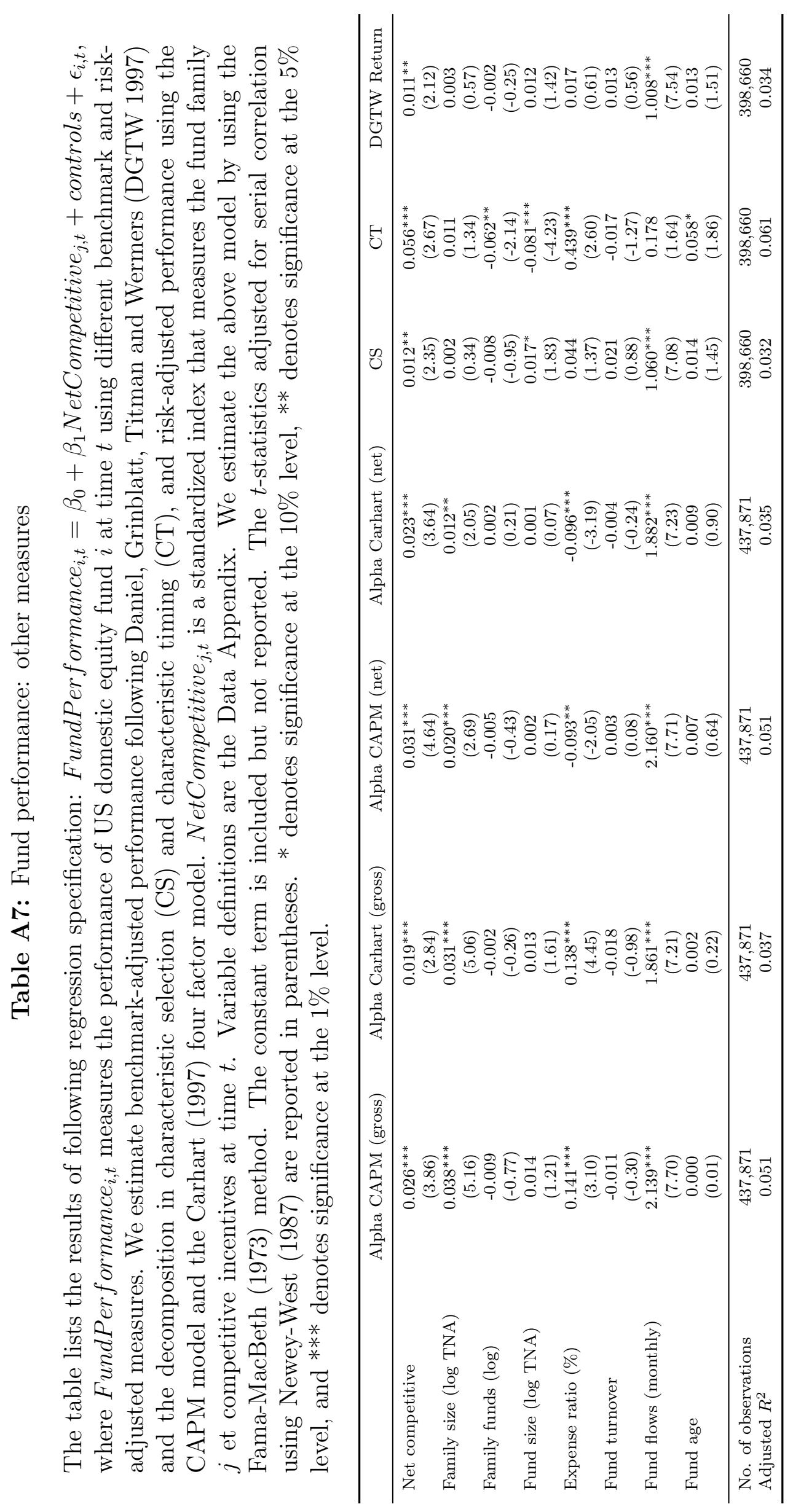


Table A8: Star funds: fund level

The table lists a logistic specification to determine the likelihood associated with a fund being a star fund. We present both the odd ratio and $t$-statistics. CompetitiveFamily/CooperativeFamily ${ }_{j, t}$ is indicator variable for families with above median competitive, cooperative and net competitive incentives scheme. We also include the Net competitive (competitive - cooperative) effect. Variable definitions are the Data Appendix. Time dummies, investment objective dummies and the constant term are also included but not reported. We estimate the above model by using logistic regression. Robust $t$-statistics adjusted for fund-level clustering are reported in parentheses. * denotes significance at the $10 \%$ level, ${ }^{* *}$ denotes significance at the $5 \%$ level, and *** denotes significance at the $1 \%$ level.

\begin{tabular}{|c|c|c|c|c|c|c|}
\hline \multirow[b]{2}{*}{ Competitive } & \multicolumn{6}{|c|}{ Prob $($ Star fund $==1)$} \\
\hline & $\begin{array}{c}1.267^{* * *} \\
(9.08)\end{array}$ & $\begin{array}{c}1.239^{* * *} \\
(8.43)\end{array}$ & & & & \\
\hline Cooperative & & & $\begin{array}{c}0.818^{* * *} \\
(-7.10)\end{array}$ & $\begin{array}{c}0.859^{* * *} \\
(-5.48)\end{array}$ & & \\
\hline Net competitive & & & & & $\begin{array}{c}1.321^{* * *} \\
(10.02)\end{array}$ & $\begin{array}{c}1.263^{* * *} \\
(8.59)\end{array}$ \\
\hline Family size (log TNA) & $\begin{array}{c}0.985 \\
(-1.11)\end{array}$ & $\begin{array}{c}0.931^{* * *} \\
(-3.42)\end{array}$ & $\begin{array}{c}0.983 \\
(-1.24)\end{array}$ & $\begin{array}{c}0.930^{* * * *} \\
(-3.38)\end{array}$ & $\begin{array}{c}1.003 \\
(0.20)\end{array}$ & $\begin{array}{c}0.951^{* *} \\
(-2.32)\end{array}$ \\
\hline Family funds (log) & $\begin{array}{l}1.030 \\
(1.04)\end{array}$ & $\begin{array}{c}1.205^{* * *} \\
(3.76)\end{array}$ & $\begin{array}{l}1.039 \\
(1.36)\end{array}$ & $\begin{array}{c}1.240^{* * *} \\
(4.25)\end{array}$ & $\begin{array}{l}1.036 \\
(1.26)\end{array}$ & $\begin{array}{c}1.214^{* * *} \\
(3.87)\end{array}$ \\
\hline Family stocks (log) & & $\begin{array}{c}0.902^{* * *} \\
(-3.37)\end{array}$ & & $\begin{array}{c}0.887^{* * *} \\
(-3.90)\end{array}$ & & $\begin{array}{c}0.899^{* * *} \\
(-3.45)\end{array}$ \\
\hline Fund size (log TNA) & & $\begin{array}{c}1.173^{* * *} \\
(4.55)\end{array}$ & & $\begin{array}{c}1.156^{* * *} \\
(4.05)\end{array}$ & & $\begin{array}{c}1.150^{* * *} \\
(3.96)\end{array}$ \\
\hline Expense ratio (\%) & & $\begin{array}{c}1.963^{* * *} \\
(11.95)\end{array}$ & & $\begin{array}{c}1.910^{* * *} \\
(11.53)\end{array}$ & & $\begin{array}{c}1.917^{* * *} \\
(11.57)\end{array}$ \\
\hline Fund turnover & & $\begin{array}{c}1.114^{* * *} \\
(5.88)\end{array}$ & & $\begin{array}{c}1.109^{* * *} \\
(5.57)\end{array}$ & & $\begin{array}{c}1.113^{* * *} \\
(5.85)\end{array}$ \\
\hline Past returns (yearly) & & $\begin{array}{c}18.889^{* * *} \\
(37.17)\end{array}$ & & $\begin{array}{c}19.110^{* * *} \\
(37.33)\end{array}$ & & $\begin{array}{c}18.835^{* * *} \\
(37.13)\end{array}$ \\
\hline Fund flows (monthly) & & $\begin{array}{l}1.000 \\
(1.12)\end{array}$ & & $\begin{array}{l}1.000 \\
(1.24)\end{array}$ & & $\begin{array}{l}1.000 \\
(1.29)\end{array}$ \\
\hline Fund ranking revenues & & $\begin{array}{l}1.010 \\
(0.59)\end{array}$ & & $\begin{array}{l}1.014 \\
(0.86)\end{array}$ & & $\begin{array}{l}1.017 \\
(1.02)\end{array}$ \\
\hline Style dummies & $\mathrm{Y}$ & $\mathrm{Y}$ & $\mathrm{Y}$ & $\mathrm{Y}$ & $\mathrm{Y}$ & $\mathrm{Y}$ \\
\hline Time dummies & $\mathrm{Y}$ & $\mathrm{Y}$ & $\mathrm{Y}$ & $\mathrm{Y}$ & $\mathrm{Y}$ & $\mathrm{Y}$ \\
\hline No. of observations & 794,685 & 780,678 & 794,685 & 780,678 & 794,685 & 780,678 \\
\hline
\end{tabular}


Table A9: Family star funds: dummy variables

The table lists the results of following regression specification: FamStarFundsj, $t=$ $\beta_{0}+\beta_{1}$ CompetitiveFamily/CooperativeFamily $_{j, t}+$ controls $+\epsilon_{j, t}$, where FamStarFundsj, $t$ is the proportion of star funds in family $j$ at time $t$. CompetitiveFamily/CooperativeFamily f $_{, t}$ is indicator variable for families with above median competitive, cooperative and net competitive incentives scheme. We also include the Net competitive (competitive - cooperative) effect. Variable definitions are the Data Appendix. We estimate the above model by using the Fama-MacBeth (1973) method. The constant term is included but not reported. The $t$-statistics adjusted for serial correlation using Newey-West (1987) are reported in parentheses. * denotes significance at the $10 \%$ level, ${ }^{* *}$ denotes significance at the $5 \%$ level, and $* * *$ denotes significance at the $1 \%$ level.

\begin{tabular}{|c|c|c|c|c|c|c|}
\hline \multirow[b]{2}{*}{ Competitive family } & \multicolumn{6}{|c|}{ Star funds strategy } \\
\hline & $\begin{array}{c}0.025^{* * *} \\
(13.28)\end{array}$ & $\begin{array}{c}0.020^{* * *} \\
(11.18)\end{array}$ & & & & \\
\hline Cooperative family & & & $\begin{array}{c}-0.024^{* * *} \\
(-6.73)\end{array}$ & $\begin{array}{c}-0.028^{* * *} \\
(-7.85)\end{array}$ & & \\
\hline Net competitive family & & & & & $\begin{array}{c}0.030^{* * *} \\
(10.30)\end{array}$ & $\begin{array}{c}0.028^{* * *} \\
(10.61)\end{array}$ \\
\hline Family size (log TNA) & $\begin{array}{c}0.010^{* * *} \\
(10.74)\end{array}$ & $\begin{array}{c}0.020^{* * *} \\
(16.67)\end{array}$ & $\begin{array}{c}0.010^{* * *} \\
(10.21)\end{array}$ & $\begin{array}{c}0.021^{* * *} \\
(16.30)\end{array}$ & $\begin{array}{c}0.011^{* * *} \\
(10.77)\end{array}$ & $\begin{array}{c}0.020^{* * *} \\
(16.87)\end{array}$ \\
\hline Family funds (log) & $\begin{array}{c}-0.025^{* * *} \\
(-7.84)\end{array}$ & $\begin{array}{c}-0.027^{* * *} \\
(-9.41)\end{array}$ & $\begin{array}{c}-0.025^{* * *} \\
(-7.81)\end{array}$ & $\begin{array}{c}-0.026^{* * *} \\
(-9.16)\end{array}$ & $\begin{array}{c}-0.025^{* * *} \\
(-7.76)\end{array}$ & $\begin{array}{c}-0.026^{* * *} \\
(-9.26)\end{array}$ \\
\hline Family age (log) & & $\begin{array}{c}-0.023^{* * *} \\
(-14.27)\end{array}$ & & $\begin{array}{c}-0.025^{* * *} \\
(-16.42)\end{array}$ & & $\begin{array}{c}-0.024^{* * *} \\
(-15.78)\end{array}$ \\
\hline Family cash & & $\begin{array}{c}0.002^{* * *} \\
(5.86)\end{array}$ & & $\begin{array}{c}0.002^{* * *} \\
(6.01)\end{array}$ & & $\begin{array}{c}0.001^{* * *} \\
(5.86)\end{array}$ \\
\hline Family expense ratio & & $\begin{array}{c}0.050^{* * *} \\
(15.80)\end{array}$ & & $\begin{array}{c}0.050^{* * *} \\
(15.81)\end{array}$ & & $\begin{array}{c}0.049^{* * *} \\
(15.41)\end{array}$ \\
\hline Family turnover & & $\begin{array}{c}0.005^{* *} \\
(2.24)\end{array}$ & & $\begin{array}{c}0.005^{* *} \\
(2.05)\end{array}$ & & $\begin{array}{c}0.005^{* *} \\
(2.27)\end{array}$ \\
\hline Family front load & & $\begin{array}{c}-0.029^{* * *} \\
(-10.18)\end{array}$ & & $\begin{array}{c}-0.031^{* * *} \\
(-10.89)\end{array}$ & & $\begin{array}{c}-0.029^{* * *} \\
(-10.25)\end{array}$ \\
\hline Family gross return & & $\begin{array}{c}0.359^{* * *} \\
(2.91)\end{array}$ & & $\begin{array}{c}0.368^{* * *} \\
(3.02)\end{array}$ & & $\begin{array}{c}0.361^{* * *} \\
(2.95)\end{array}$ \\
\hline No. of observations & 105,435 & 105,299 & 105,435 & 105,299 & 105,435 & 105,299 \\
\hline Adjusted $R^{2}$ & 0.016 & 0.072 & 0.019 & 0.076 & 0.019 & 0.074 \\
\hline
\end{tabular}


Table A10: Performance dispersion: dummy variables

The table lists the results of following regression specification: $\operatorname{PerfDisp}_{j, t}=\beta_{0}+$ $\beta_{1}$ CompetitiveFamily/CooperativeFamily $_{j, t}+$ controls $+\epsilon_{j, t}$, where PerfDisp $p_{j, t}$ is the cross-sectional standard deviation of objective-adjusted fund returns of family $j$ at time $t$. CompetitiveFamily/CooperativeFamily F $_{j, t}$ is indicator variable for families with above median competitive, cooperative and net competitive incentives scheme. We also include the Net competitive (competitive - cooperative) effect. Variable definitions are the Data Appendix. We estimate the above model by using the Fama-MacBeth (1973) method. The constant term is included but not reported. The $t$-statistics adjusted for serial correlation using Newey-West (1987) are reported in parentheses. * denotes significance at the $10 \%$ level, $* *$ denotes significance at the $5 \%$ level, and $* * *$ denotes significance at the $1 \%$ level.

\begin{tabular}{|c|c|c|c|c|c|c|}
\hline \multirow[b]{2}{*}{ Competitive family } & \multicolumn{6}{|c|}{ Family performance dispersion } \\
\hline & $\begin{array}{c}0.056^{* * *} \\
(6.00)\end{array}$ & $\begin{array}{c}0.033^{* * *} \\
(3.85)\end{array}$ & & & & \\
\hline Cooperative family & & & $\begin{array}{c}-0.041^{* * *} \\
(-5.06)\end{array}$ & $\begin{array}{c}-0.043^{* * *} \\
(-4.56)\end{array}$ & & \\
\hline Net competitive family & & & & & $\begin{array}{c}0.096^{* * *} \\
(10.14)\end{array}$ & $\begin{array}{c}0.066^{* * *} \\
(6.66)\end{array}$ \\
\hline Family size (log TNA) & $\begin{array}{c}-0.016^{* * *} \\
(-4.05)\end{array}$ & $\begin{array}{c}0.027^{* * *} \\
(5.96)\end{array}$ & $\begin{array}{c}-0.016^{* * *} \\
(-4.06)\end{array}$ & $\begin{array}{c}0.029^{* * *} \\
(6.32)\end{array}$ & $\begin{array}{c}-0.013^{* * *} \\
(-3.30)\end{array}$ & $\begin{array}{c}0.029^{* * *} \\
(6.36)\end{array}$ \\
\hline Family funds (log) & $\begin{array}{c}0.085^{* * *} \\
(7.60)\end{array}$ & $\begin{array}{c}0.038^{* * *} \\
(6.21)\end{array}$ & $\begin{array}{c}0.084^{* * *} \\
(7.75)\end{array}$ & $\begin{array}{c}0.038^{* * *} \\
(6.43)\end{array}$ & $\begin{array}{c}0.089^{* * *} \\
(8.13)\end{array}$ & $\begin{array}{c}0.040^{* * *} \\
(6.77)\end{array}$ \\
\hline Family age (log) & & $\begin{array}{c}0.020^{* *} \\
(2.26)\end{array}$ & & $\begin{array}{c}0.018^{* *} \\
(2.02)\end{array}$ & & $\begin{array}{c}0.018^{* *} \\
(2.01)\end{array}$ \\
\hline Family cash & & $\begin{array}{c}0.007^{* * *} \\
(7.06)\end{array}$ & & $\begin{array}{c}0.008^{* * *} \\
(7.42)\end{array}$ & & $\begin{array}{c}0.007^{* * *} \\
(7.05)\end{array}$ \\
\hline Family expense ratio & & $\begin{array}{c}0.497^{* * *} \\
(23.23)\end{array}$ & & $\begin{array}{c}0.499^{* * *} \\
(23.69)\end{array}$ & & $\begin{array}{c}0.494^{* * *} \\
(23.43)\end{array}$ \\
\hline Family turnover & & $\begin{array}{c}0.114^{* * *} \\
(8.91)\end{array}$ & & $\begin{array}{c}0.115^{* * *} \\
(8.99)\end{array}$ & & $\begin{array}{c}0.117^{* * *} \\
(9.15)\end{array}$ \\
\hline Family front load & & $\begin{array}{c}-0.121^{* * *} \\
(-11.33)\end{array}$ & & $\begin{array}{c}-0.124^{* * *} \\
(-11.50)\end{array}$ & & $\begin{array}{c}-0.121^{* * *} \\
(-11.20)\end{array}$ \\
\hline Family gross return & & $\begin{array}{l}1.198^{*} \\
(1.73)\end{array}$ & & $\begin{array}{l}1.226^{*} \\
(1.76)\end{array}$ & & $\begin{array}{l}1.216^{*} \\
(1.76)\end{array}$ \\
\hline No. of observations & 86,333 & 86,209 & 86,333 & 86,209 & 86,333 & 86,209 \\
\hline Adjusted $R^{2}$ & 0.009 & 0.144 & 0.008 & 0.144 & 0.011 & 0.145 \\
\hline
\end{tabular}


Table A11: Recapturing flows

This table reports estimates of regressions of monthly fund outflows on family and fund characteristics. The fund outflows data come from N-SAR question 28a-f. The independent variables include a standardized index that measures the fund family competitive incentives (Competitive), a standardized index that measures the fund family cooperative incentives (Cooperative), the average outflows to all other funds in the fund family (Family outflows), the family size and number of funds, the size, expense ratio, turnover, performance, fund ranking revenues, the lagged fund outflows (Fund outflows $t-1$ ), and the average outflows to all funds in the same investment objective (Style outflows). Variable definitions are the Data Appendix. We estimate the above model by using the Fama-MacBeth (1973) method. The constant term is included but not reported. The $t$-statistics adjusted for serial correlation using Newey-West (1987) are reported in parentheses. * denotes significance at the $10 \%$ level, $* *$ denotes significance at the $5 \%$ level, and ${ }^{* * *}$ denotes significance at the $1 \%$ level.

\begin{tabular}{|c|c|c|c|c|c|c|}
\hline \multirow[b]{2}{*}{ Competitive } & \multicolumn{6}{|c|}{ Fund outflows } \\
\hline & $\begin{array}{c}0.110^{* * *} \\
(6.38)\end{array}$ & $\begin{array}{c}0.093^{* * *} \\
(5.09)\end{array}$ & & & $\begin{array}{c}0.112^{* * *} \\
(5.32)\end{array}$ & $\begin{array}{c}0.088^{* * *} \\
(4.13)\end{array}$ \\
\hline Cooperative & & & $\begin{array}{c}-0.045^{* *} \\
(-2.54)\end{array}$ & $\begin{array}{c}-0.052^{* * *} \\
(-2.81)\end{array}$ & $\begin{array}{l}-0.005 \\
(-0.26)\end{array}$ & $\begin{array}{l}-0.018 \\
(-0.89)\end{array}$ \\
\hline Competitive $\mathrm{x}$ Family inflows & $\begin{array}{c}-0.030^{* * *} \\
(-4.59)\end{array}$ & $\begin{array}{c}-0.026^{* * *} \\
(-3.95)\end{array}$ & & & $\begin{array}{c}-0.027^{* * *} \\
(-3.62)\end{array}$ & $\begin{array}{c}-0.024^{* * *} \\
(-3.30)\end{array}$ \\
\hline Cooperative $\mathrm{x}$ Family inflows & & & $\begin{array}{c}0.020^{* * *} \\
(3.12)\end{array}$ & $\begin{array}{c}0.013^{* *} \\
(1.98)\end{array}$ & $\begin{array}{c}0.014^{* *} \\
(2.07)\end{array}$ & $\begin{array}{c}0.008 \\
(1.12)\end{array}$ \\
\hline Family inflows & $\begin{array}{c}0.267^{* * *} \\
(28.17)\end{array}$ & $\begin{array}{c}0.265^{* * *} \\
(28.35)\end{array}$ & $\begin{array}{c}0.274^{* * *} \\
(26.24)\end{array}$ & $\begin{array}{c}0.271^{* * *} \\
(26.44)\end{array}$ & $\begin{array}{c}0.264^{* * *} \\
(29.06)\end{array}$ & $\begin{array}{c}0.262^{* * *} \\
(29.15)\end{array}$ \\
\hline Fund outflows t- 1 & $\begin{array}{c}0.699^{* * *} \\
(53.23)\end{array}$ & $\begin{array}{c}0.687^{* * *} \\
(51.99)\end{array}$ & $\begin{array}{c}0.702^{* * *} \\
(55.64)\end{array}$ & $\begin{array}{c}0.689^{* * *} \\
(54.37)\end{array}$ & $\begin{array}{c}0.704^{* * *} \\
(55.29)\end{array}$ & $\begin{array}{c}0.692^{* * *} \\
(53.95)\end{array}$ \\
\hline Style outflows & $\begin{array}{c}0.389^{* * *} \\
(16.04)\end{array}$ & $\begin{array}{c}0.371^{* * *} \\
(13.48)\end{array}$ & $\begin{array}{c}0.378^{* * *} \\
(15.54)\end{array}$ & $\begin{array}{c}0.361^{* * *} \\
(12.78)\end{array}$ & $\begin{array}{c}0.382^{* * *} \\
(15.72)\end{array}$ & $\begin{array}{c}0.367^{* * *} \\
(13.21)\end{array}$ \\
\hline Family size (log TNA) & & $\begin{array}{c}0.136^{* * *} \\
(11.53)\end{array}$ & & $\begin{array}{c}0.138^{* * *} \\
(11.50)\end{array}$ & & $\begin{array}{c}0.136^{* * *} \\
(11.50)\end{array}$ \\
\hline Family funds (log) & & $\begin{array}{c}-0.028^{* * *} \\
(-2.75)\end{array}$ & & $\begin{array}{c}-0.023^{* *} \\
(-2.17)\end{array}$ & & $\begin{array}{c}-0.032^{* * *} \\
(-3.06)\end{array}$ \\
\hline Fund size $(\log$ TNA) & & $\begin{array}{c}-0.301^{* * *} \\
(-14.20)\end{array}$ & & $\begin{array}{c}-0.306^{* * *} \\
(-14.28)\end{array}$ & & $\begin{array}{c}-0.299^{* * *} \\
(-14.20)\end{array}$ \\
\hline Expense ratio (\%) & & $\begin{array}{c}0.065^{* * *} \\
(2.91)\end{array}$ & & $\begin{array}{c}0.055^{* *} \\
(2.42)\end{array}$ & & $\begin{array}{c}0.062^{* * *} \\
(2.79)\end{array}$ \\
\hline Fund turnover & & $\begin{array}{c}0.087^{* * *} \\
(5.64)\end{array}$ & & $\begin{array}{c}0.107^{* * *} \\
(6.52)\end{array}$ & & $\begin{array}{c}0.089^{* * *} \\
(5.90)\end{array}$ \\
\hline Gross performance & & $\begin{array}{c}-0.063^{* * *} \\
(-8.23)\end{array}$ & & $\begin{array}{c}-0.064^{* * *} \\
(-8.36)\end{array}$ & & $\begin{array}{c}-0.063^{* * *} \\
(-8.30)\end{array}$ \\
\hline Fund ranking revenues & & $\begin{array}{c}0.040^{* * *} \\
(5.44)\end{array}$ & & $\begin{array}{c}0.042^{* * *} \\
(5.54)\end{array}$ & & $\begin{array}{c}0.039^{* * *} \\
(5.25)\end{array}$ \\
\hline Style dummies & $\mathrm{Y}$ & $\mathrm{Y}$ & $\mathrm{Y}$ & $\mathrm{Y}$ & $\mathrm{Y}$ & $\mathrm{Y}$ \\
\hline No. of observations & 607,815 & 600,576 & 607,815 & 600,576 & 607,815 & 600,576 \\
\hline Adjusted $R^{2}$ & 0.683 & 0.688 & 0.681 & 0.687 & 0.685 & 0.690 \\
\hline
\end{tabular}


Table A12: Coordinated behavior: other variables

The table lists the results of the following regression specification: Coordination $_{j, t}=$ $\beta_{0}+\beta_{1}$ NetCompetitive $_{j, t}+$ controls $+\epsilon_{j, t}$, where Coordination $_{j, t}$ proxies for coordinated behavior and resource sharing. Cross-assets trading is the average frequency in which both equity and bond funds simultaneously hold a security of the same firm as a fraction of the total number of holdings in the asset management company. Stock weight \% funds is the average across all stocks in the family of the number of portfolios holding a stock over the number of portfolios in the family. Stock weight \% assets is a Herfindahl index of the fund family holdings, more precisely its the sum of the squares of the portfolio holdings within a fund family weighted by the family total holdings size. Adopt time is the average across funds in the family of the time lapsed in quarters between the initiation of the position (the date the first fund in the family purchased the stock over the past year) and when other funds in the family also purchased the stock. Variable definitions are the Data Appendix. We estimate the above model by using the Fama-MacBeth (1973) method. The constant term is included but not reported. The $t$-statistics adjusted for serial correlation using Newey-West (1987) are reported in parentheses. * denotes significance at the $10 \%$ level, ${ }^{* *}$ denotes significance at the $5 \%$ level, and $* * *$ denotes significance at the $1 \%$ level.

\begin{tabular}{lcccc}
\hline \hline & Cross-assets trading & Stock weight \% funds & Stock weight \% assets & Adopt time \\
\hline Net competitive & $-1.034^{* * *}$ & $-0.115^{* * *}$ & $-0.143^{* *}$ & $0.625^{* * *}$ \\
& $(-6.85)$ & $(-2.68)$ & $(-2.06)$ & $(5.25)$ \\
Family size (log TNA) & $1.824^{* * *}$ & $0.239^{* * *}$ & $0.274^{* * *}$ & 0.048 \\
& $(6.63)$ & $(5.89)$ & $(8.83)$ & $(1.04)$ \\
Family age $(\log )$ & $2.401^{* * *}$ & $-0.584^{* * *}$ & $(-0.080$ & $5.235^{* * *}$ \\
& $(10.23)$ & $-1.671^{* * *}$ & $(-0.81)$ & $(15.71)$ \\
Family funds $(\log )$ & $4.938^{* * *}$ & $(-18.25)$ & $-1.524^{* * *}$ & $1.056^{* * *}$ \\
& $(6.35)$ & $0.545^{* * *}$ & $(-21.46)$ & $(6.84)$ \\
Family turnover & $0.977^{* * *}$ & $(5.86)$ & $0.804^{* * *}$ & $-0.949^{* * *}$ \\
& $(4.96)$ & $-0.067^{* *}$ & $(9.23)$ & $(-7.41)$ \\
Gross performance & 0.049 & $(-2.22)$ & -0.072 & 0.060 \\
& $(0.71)$ & 127,880 & $(-1.64)$ & $(1.45)$ \\
\hline No. of observations & 52,254 & 0.085 & 127,880 & 0.023 \\
Adjusted $R^{2}$ & 0.200 & & & 0.094 \\
\hline \hline
\end{tabular}


Table A13: Robustness checks: financial conglomerates

After is a dummy equal 1 for families that are part of a large financial conglomerates. Variable definitions are the Data Appendix. The constant term is included but not reported. The $t$-statistics are reported in parentheses, standard errors are clustered at the family level. * denotes significance at the $10 \%$ level, $* *$ denotes significance at the $5 \%$ level, and $* * *$ denotes significance at the $1 \%$ level.

\begin{tabular}{|c|c|c|c|c|c|}
\hline & \multicolumn{5}{|c|}{ Financial conglomerates } \\
\hline & Family stars & Performance dispersion & Cross-trading & Active share & Tracking err \\
\hline \multirow[t]{2}{*}{ Financial conglomerate parent } & -0.021 & 0.049 & 0.051 & -0.007 & -0.007 \\
\hline & $(-1.30)$ & $(0.68)$ & $(0.89)$ & $(-0.25)$ & $(-1.32)$ \\
\hline \multirow[t]{2}{*}{ Net competitive } & $0.021^{* * *}$ & $0.047^{* *}$ & $-0.037^{* * *}$ & $0.009^{*}$ & $0.005^{* * *}$ \\
\hline & $(5.58)$ & $(2.43)$ & $(-2.84)$ & $(1.93)$ & $(3.56)$ \\
\hline Financial conglomerate parent & -0.005 & 0.045 & 0.013 & 0.032 & -0.006 \\
\hline$\times$ Net competitive & $(-0.37)$ & $(0.80)$ & $(0.22)$ & $(1.48)$ & $(-1.35)$ \\
\hline \multirow[t]{2}{*}{ Family size (log TNA) } & $0.022^{* * *}$ & $0.034^{* * *}$ & 0.007 & $0.005^{*}$ & 0.000 \\
\hline & $(10.58)$ & $(3.22)$ & $(0.86)$ & $(1.86)$ & $(0.10)$ \\
\hline \multirow[t]{2}{*}{ Family funds (log) } & $-0.025^{* * *}$ & $0.047^{* *}$ & $0.030^{* *}$ & $-0.030^{* * *}$ & $-0.005^{* * *}$ \\
\hline & $(-5.93)$ & $(2.53)$ & $(1.97)$ & $(-5.30)$ & $(-4.46)$ \\
\hline \multirow{2}{*}{ Family age (log) } & $-0.026^{* * *}$ & 0.022 & 0.004 & -0.006 & -0.000 \\
\hline & $(-5.29)$ & $(1.09)$ & $(0.19)$ & $(-1.00)$ & $(-0.04)$ \\
\hline \multirow[t]{2}{*}{ Family cash } & $0.001^{* * *}$ & $0.005^{*}$ & -0.001 & 0.001 & $0.001^{* * *}$ \\
\hline & $(3.27)$ & $(1.68)$ & $(-0.97)$ & $(1.02)$ & $(3.26)$ \\
\hline \multirow[t]{2}{*}{ Family expense ratio } & $0.057^{* * *}$ & $0.585^{* * *}$ & $-0.079^{* *}$ & $0.097^{* * *}$ & $0.034^{* * *}$ \\
\hline & $(7.19)$ & $(13.12)$ & $(-2.48)$ & $(8.14)$ & $(7.82)$ \\
\hline \multirow[t]{2}{*}{ Family turnover } & 0.007 & $0.158^{* * *}$ & 0.004 & -0.010 & $0.007^{* * *}$ \\
\hline & $(1.64)$ & $(4.87)$ & $(0.28)$ & $(-1.46)$ & $(2.89)$ \\
\hline \multirow[t]{2}{*}{ Family front load } & $-0.033^{* * *}$ & $-0.174^{* * *}$ & $0.119^{* * *}$ & $-0.037^{* * *}$ & $-0.014^{* * *}$ \\
\hline & $(-4.34)$ & $(-4.18)$ & $(3.61)$ & $(-3.28)$ & $(-4.17)$ \\
\hline Time dummies & $\mathrm{Y}$ & $\mathrm{Y}$ & $\mathrm{Y}$ & $\mathrm{Y}$ & $\mathrm{Y}$ \\
\hline No. of observations & 105,299 & 86,209 & 49,009 & 93,492 & 93,492 \\
\hline Adjusted $R^{2}$ & 0.056 & 0.402 & 0.152 & 0.193 & 0.351 \\
\hline
\end{tabular}

